\title{
1 Seawater-derived rare earth element addition to abyssal peridotites during
}

2 serpentinization

$$
\text { Carl Frisby }{ }^{\mathrm{a}} \text {, Michael Bizimis }{ }^{\mathrm{a}^{*}} \text {, Soumen Mallick } \mathrm{k}^{\mathrm{a}, 1}
$$

$4 \quad{ }^{\mathrm{a}}$ Department of Earth and Ocean Sciences, University of South Carolina, Columbia, SC

529208 , United States

$6{ }^{1}$ Now at: Department of Earth, Environmental and Planetary Sciences, Brown University,

7 Providence, RI 02912, United States

$8 \quad *$ Corresponding Author: mbizimis@geol.sc.edu

9

10

11

12

13

14

15

16

17

18

19 


\section{Abstract}

21 Serpentinized abyssal peridotites are evidence for active communication between the

22 Earth's hydrosphere and the upper mantle, where exchange and retention of both major

23 and trace elements occur. Bulk rock Nd isotopes in serpentinized abyssal peridotites

24 imply interaction of seawater with the peridotite. In contrast, the $\mathrm{Nd}$ isotopes of

25 clinopyroxenes from serpentinized abyssal peridotites retain their primary magmatic

26 signature. It is currently unclear if, how and where seawater-derived $\mathrm{Nd}$ and other REE

27 are being added or exchanged with the mantle peridotite minerals during serpentinization.

28 To remedy this knowledge gap, we present in situ trace and major element

29 concentrations, bulk rock and sequential leaching experiment trace element

30 concentrations as well as $\mathrm{Nd}, \mathrm{Sr}$ isotope data on refertilized and depleted serpentinized

31 abyssal peridotites from the Southwest Indian Ridge. The secondary serpentine matrix

32 and magnetite veins in these peridotites have elevated LREE concentrations, with

33 variable negative $\mathrm{Ce}$ anomalies and large $\mathrm{Rb}, \mathrm{Sr}, \mathrm{Pb}$ and $\mathrm{U}$ enrichments that resemble

34 seawater trace element patterns. The LREE concentrations in the serpentine phase are

35 higher than those expected for the primary mantle mineralogy (olivine, orthopyroxene)

36 based on data from relic clinopyroxenes and equilibrium partition coefficients. These data

37 are consistent with seawater-derived REE addition to the peridotite during

38 serpentinization. The bulk rocks have more radiogenic $\mathrm{Sr}$ and more unradiogenic $\mathrm{Nd}$

39 isotopes than their clinopyroxene (up to $8 \varepsilon_{\mathrm{Nd}}$ units lower than clinopyroxene).

40 Sequential leaching experiments designed to mobilize secondary carbonates and $\mathrm{Fe}-$

41 oxides show even more unradiogenic $\mathrm{Nd}$ isotope ratios in the leachates than the bulk rock

42 and clinopyroxene, approaching seawater compositions (up to $15 \varepsilon_{\mathrm{Nd}}$ units lower than 
43 clinopyroxene). Mass balance calculations using trace elements or Nd isotopes suggest

44 that up to $30 \%$ of the bulk peridotite Nd budget is of seawater origin and was added to the

45 peridotite, as opposed to being exchanged. These data allows for more accurate

46 constraints of the water/rock mass exchange ratios during serpentinization in these rocks

47 ( 1000 to 17000) that are at least an order of magnitude lower than using typical mantle

48 and seawater endmembers. These data provide strong evidence that serpentinization may

49 also be a sink for the light REE, with implications for the refertilization of the peridotite

50 during serpentinization, and the cycling of these elements through the subduction system

51 and into the upper mantle.

\section{Keywords}

53 Serpentinization; abyssal peridotite; rare earth elements; negative $\mathrm{Ce}$ anomaly; $\mathrm{Sr}$ -

54 isotopes; Nd-isotopes; Laser ablation ICP-MS; sequential leaching. 


\subsection{Introduction}

Submarine peridotite- hosted hydrothermal systems are the interface between the

57 Earth's oceans and the mantle, where significant elemental exchange takes place during

58 the serpentinization of peridotitic rocks. Serpentinization leads to the uptake of $\mathrm{H}_{2} \mathrm{O}$ into

59 the peridotite, the redistribution of major cations (i.e. $\mathrm{Mg}, \mathrm{Ca}, \mathrm{Si}, \mathrm{Fe}$ and $\mathrm{C}$ ) among the

60 newly formed secondary minerals (serpentine, magnetite, and brucite), addition of fluid-

61 mobile elements (e.g. B, Cs, I, Sr, U) and the generation of $\mathrm{Mg}$ poor, $\mathrm{CH}_{4}-$ and $\mathrm{H}_{2}$ - rich,

62 alkaline hydrothermal fluids (Allen and Seyfried, 2003; Synder et al., 2004; Paulick et al.,

63 2006; Savov et al., 2007; Beard et al., 2009; Bach and Früh-Green, 2010; Deschamps et

64 al., 2013).

65 Whether rare earth elements (REE) and high field strength elements (HSFE; Nb,

$66 \mathrm{Ta}, \mathrm{Zr}, \mathrm{Hf}, \mathrm{Ti})$ are mobilized or fractionated during serpentinization is unclear. On one

67 hand, the positive correlations of REE concentrations with highly immobile incompatible

68 elements like Th was taken as evidence that serpentinized peridotites preserve their

69 primary magmatic (high temperature) REE systematics (Niu, 2004; Paulick et al., 2006)

70 and that the REE can be used to constrain the primary mineralogy and magmatic history

71 of the peridotite prior to alteration (e.g., Deschamps et al., 2010). Light REE enrichments

72 in the bulk rock serpentinized peridotites relative to the fresh clinopyroxene in the same

73 samples (Niu, 2004) imply some decoupling of REE within these rocks. This decoupling

74 is generally attributed to transient melt infiltration in the peridotite, where a melt

75 percolated and perhaps "froze" along grain boundaries and where the clinopyroxene did

76 not significantly react with that melt (Niu, 2004). 
In contrast, experimental work suggests REE mobilization into the hydrothermal

78 fluid during serpentinization (Allen and Seyfried, 2005), suggesting that REE may be

79 mobile during alteration. A similar inference was made based on some bulk rock

80 serpentinite compositions from IODP Leg 209, subject to high water / rock ratio reaction

81 (Paulick et al., 2006; Jöns et al., 2010). Furthermore, Sr, Nd isotopic evidence show

82 higher ${ }^{87} \mathrm{Sr} /{ }^{86} \mathrm{Sr}$ and lower $\varepsilon_{\mathrm{Nd}}$ for serpentinized abyssal peridotites exposed on the

83 seafloor near spreading centers (McCulloch et al., 1980; Menzies et al., 1993; Snow and

84 Reisberg, 1995; Delacour et al., 2008; Harvey et al., 2014) relative to typical mantle

85 values recorded in abyssal peridotite clinopyroxenes (Salters and Dick, 2002; Ciprianni et

86 al., 2004; Warren et al., 2009, Mallick et al., 2014), and with isotope compositions that

87 approach that of seawater. These data imply isotopic disequilibrium between bulk rock

88 peridotite and clinopyroxenes isotope ratios, although to our knowledge there has not

89 been any systematic work to assess clinopyroxene and bulk rock $\mathrm{Sr}$ and $\mathrm{Nd}$ isotope

90 compositions in the same sample. From the coupled $\mathrm{Sr}, \mathrm{Nd}$ isotope systematics of bulk

91 rock peridotites, water / rock mass ratio have been inferred to understand serpentinization

92 and examine mass exchange between seawater and the Earth's upper mantle (Foustoukos

93 et al., 2007; Delacour et al., 2008). As a result of this apparent disequilibrium it is

94 currently unclear if and to what extent the REE budget of peridotites can be affected by

95 serpentinization and seafloor weathering reactions.

96 Here we present a detailed investigation of in situ (laser ablation ICP-MS) and

97 bulk major and trace element concentrations, as well as solution $\mathrm{Sr}$ and $\mathrm{Nd}$ isotopic

98 compositions by MC-ICP-MS on primary and secondary mineralogy (through sequential

99 leaching experiments) of six serpentinized abyssal peridotites from the Southwest Indian 
100 Ridge. The selected samples have preserved primary clinopyroxene and occasionally

101 orthopyroxene while most of olivine has been altered to serpentine. The relic

102 clinopyroxenes preserve the original mantle signature and have been previously

103 characterized for their magmatic elemental and Sr, Nd, Hf compositions (Mallick et al.,

104 2014; Mallick et al., 2015). The detailed elemental and isotope comparison between bulk

105 rock (altered) and clinopyroxene (magmatic) signatures allows to constrain whether REE

106 have been added or exchanged between the reactant seawater and peridotite during

107 serpentinization. We show that the secondary mineralogy (especially serpentine after

108 olivine and orthopyroxene) has a strong seawater - like signature with negative Ce

109 anomalies and $\mathrm{Sr}, \mathrm{Nd}$ isotopes approaching seawater. This data allows us to reevaluate

110 the utility of Sr-Nd isotope systematics as tracers of water rock ratios, the residence of

111 trace elements in secondary minerals in serpentinized peridotites and the extent of REE

112 exchange between mantle and seawater.

\section{$113 \quad$ 2.0 Sample Description}

114 The analyzed abyssal peridotites are from two on-ridge locations along the

115 Southwest Indian Ridge (SWIR: Dick et al., 2003; Standish et al., 2008) on opposite sides

116 of the $16^{\circ} \mathrm{E}$ discontinuity (Supplementary Figure 1). Peridotites from $15.23^{\circ} \mathrm{E}$ (axial

117 trough, subsequently labeled VAN 7-85 samples) sit on an oblique segment of the

118 spreading ridge, while those from the $16.64^{\circ} \mathrm{E}$ location (fault scarp, subsequently labeled

119 VAN 7-78 samples) are from the orthogonal segment of the spreading ridge as defined by

120 the angle between the spreading direction and the ridge axis (see Dick et al., 2003;

121 Standish et al., 2008 for geodynamic details). These samples have been studied in detail

122 for petrography, major, trace element, $\mathrm{Sr}, \mathrm{Nd}$ and $\mathrm{Hf}$ isotope compositions in 
123 clinopyroxene and major element compositions in spinel (Warren et al., 2009; Mallick et

124 al., 2014; Mallick et al., 2015). Clinopyroxenes from the $15.23^{\circ} \mathrm{E}$ peridotites have low

$125 \mathrm{TiO}_{2}(\leq 0.24 \mathrm{wt} \%)$ and $\mathrm{Na}_{2} \mathrm{O}(\leq 0.52 \mathrm{wt} \%)$, sub-chondritic LREE/HREE ratios and spinels

126 with low $\mathrm{TiO}_{2}(\leq 0.11 \mathrm{wt} \%)$. These data suggest minimal interaction with a melt and the

$127 \quad 15.23^{\circ} \mathrm{E}$ peridotites are interpreted as nearly pure melt residues of $\sim 8 \%$ melt depletion

128 from a DMM source (Mallick et al, 2014). Peridotites from $16.64^{\circ} \mathrm{E}$ are interpreted as re-

129 fertilized peridotites due to the frequent presence of plagioclase, high $\mathrm{TiO}_{2}$ (up to 0.53

$130 \mathrm{wt} \%$ ) and $\mathrm{Na}_{2} \mathrm{O}$ (up to $1.57 \mathrm{wt} \%$ ) along with often super-chondritic LREE/HREE ratios

131 in clinopyroxene, and spinels with high $\mathrm{TiO}_{2}$ (up to $0.46 \mathrm{wt} \%$; Warren et al., 2009;

132 Mallick et al., 2014; Mallick et al., 2015). Based on the Hf, Nd isotope compositions of

133 the clinopyroxene from the SWIR peridotites and co-located basalts, Mallick et al. (2015)

134 concluded that the depletion (for $15.23^{\circ} \mathrm{E}$ peridotites) and post-melting enrichment (for

$13516.64^{\circ} \mathrm{E}$ peridotites) processes are related to recent processes beneath the ridge and where

136 the $15.23^{\circ} \mathrm{E}$ peridotites are consistent with a local depleted endmember of the MORB

137 source mantle.

138 Common textural features of serpentinization in these samples are shown in SEM

139 images (Fig. 1). Samples are dominated by a serpentine matrix ranging from black (VAN

$140 \quad 7-78-36 \mathrm{H}$ and VAN 7-78-41) to a yellow-green (VAN 7-78-39 and VAN 7-85 samples)

141 in appearance, with crosscutting fibrous veins of magnetite centrally aligned within the

142 serpentine veins. Notably, magnetite is isolated from the primary minerals (Figs. 1A, 1B,

143 1C). These features are consistent with the "type-2" veins described by Beard et al.,

144 (2009), of magnesian serpentine - magnetite associations in a fluid-dominated system.

145 Transect analyses by SEM across the magnetite veins show a decrease in $\mathrm{Fe}$ 
146 concentration and increase in $\mathrm{Mg \#}$ in the serpentine towards the magnetite vein, also

147 similar to the "type-2" veins of Beard et al. (2009). These observations imply that

148 magnetite is not precipitating directly out of olivine but formed likely as a reaction

149 between pre-existing serpentine-brucite assemblage and fluid (Beard et al., 2009). In

150 general, magnetite in the VAN 7-78 samples is distributed throughout the serpentine

151 matrix with typical widths of $30-80 \mu \mathrm{m}$. In the VAN 7-85 samples magnetite veins are

152 more abundant in the serpentine matrix with typically smaller vein sizes of $10-40 \mu \mathrm{m}$.

153 Tan, fibrous serpentine polymorphs (bastites) of primary minerals, after

154 orthopyroxene and olivine, are found within the VAN 7-78-39 and VAN 7-85- samples.

155 At the mineral boundaries between orthopyroxene / serpentine and olivine / serpentine we

156 observe dissolution features appearing as irregular undulating grain boundaries (Fig 1E,

157 1F). Orthopyroxene lamellae exsolved in clinopyroxene show preferential replacement

158 by serpentine relative to clinopyroxene (Fig. 1D). Flow structures are seen in the

159 serpentine recording localized stresses, and sometime crosscut by secondary Fe depleted

160 serpentine veins (Figs. 1E, 1F). Our laser ablation investigation is focused on the

161 elemental systematics of these type -2 serpentine veins, which dominate the matrix of

162 these samples.

\section{$163 \quad 3.0$ Methods}

164 All chemical analyses and measurements where performed at the Center for

165 Elemental Mass Spectrometry, Department of Earth and Ocean Sciences, University of

166 South Carolina. All acids used were produced in-house by single $\left(\mathrm{HF}\right.$ and $\left.\mathrm{HNO}_{3}\right)$ or

167 double sub-boiling distillation $(\mathrm{HCl}) .18 \mathrm{M} \Omega$ water was produced through a Millipore

168 Super-Q system. All sample handling and acid dispensing was in a metal-free clean lab. 
169 All dry downs were performed in custom-made double-HEPA filtered forced air hot

170 plates. All bulk rock concentration analyses were performed on a Thermo ELEMENT 2

171 HR-ICPMS, using Indium as internal standard, and standardized against the BHVO-2

172 USGS rock material using the preferred concentrations from the GEOROC database.

\section{3.1 Laser Ablation:}

174 Fragments of the samples were mounted in epoxy, polished to $1 \mu \mathrm{m}$ with $\mathrm{Al}_{2} \mathrm{O}_{3}$

175 powder and characterized and imaged with a reflected light petrographic microscope and

176 a Tescan Vega3 SBU Variable Pressure SEM equipped with an EDX system for

177 composition determinations, at the Electron Microscopy Center, University of South

178 Carolina. In situ mineral major $\left({ }^{23} \mathrm{Na},{ }^{29} \mathrm{Si},{ }^{27} \mathrm{Al},{ }^{25} \mathrm{Mg},{ }^{44} \mathrm{Ca},{ }^{47} \mathrm{Ti},{ }^{53} \mathrm{Cr},{ }^{57} \mathrm{Fe},{ }^{55} \mathrm{Mn},{ }^{60} \mathrm{Ni}\right)$

179 and trace $\left({ }^{88} \mathrm{Sr},{ }^{89} \mathrm{Y},{ }^{90} \mathrm{Zr},{ }^{137} \mathrm{Ba},{ }^{139} \mathrm{La},{ }^{140} \mathrm{Ce},{ }^{141} \mathrm{Pr},{ }^{146} \mathrm{Nd},{ }^{149} \mathrm{Sm},{ }^{157} \mathrm{Gd},{ }^{163} \mathrm{Dy},{ }^{167} \mathrm{Er}\right.$,

$\left.180{ }^{173} \mathrm{Yb},{ }^{175} \mathrm{Lu},{ }^{178} \mathrm{Hf},{ }^{208} \mathrm{~Pb},{ }^{232} \mathrm{Th},{ }^{238} \mathrm{U}\right)$ element concentrations where determined using a

181 Photon Machines UV-Eximer 193nm laser ablation system with a HELIX 2 sample cell

182 in He-atmosphere, coupled to a Thermo ELEMENT 2 HR-ICP-MS. Concentrations were

183 determined by spot ablation with an $110 \mu \mathrm{m}$ spot at $8 \mathrm{~Hz}$ with $\sim 11 \mathrm{~J} / \mathrm{cm}^{2}$ fluence.

184 Additional laser settings can be found in Table 1. Due to the size of the laser beam and

185 potential fine scale heterogeneity of serpentine (e.g. Frost and Beard, 2007; Frost et al.,

186 2013) and orthopyroxene due to exsolutions, we determined the major element

187 compositions of each spot following the method of Humayun et al. (2010) where

188 background corrected peak intensities are converted to oxide concentration ratio with

189 respect to silica using relative sensitivity factors (RSF) defined as:

$$
R S F=\left(C_{i} / C_{S i O 2}\right) /\left(I_{i} / I_{29 S i}\right)
$$


191 where $C_{i}$ is the concentration of element or oxide $i$, and $I_{i}$ is the intensity of the element or

192 oxide peak. Relative sensitivity factors were obtained from multiple analyses of the glass

193 reference materials NIST 612 and BHVO-2G, BIR-1G.

194 Application of the RSFs required the $\mathrm{SiO}_{2}$ content to be determined using the

195 equation:

$$
\mathrm{SiO}_{2}=100 / 2\left(x_{i} / \mathrm{SiO}_{2}\right)
$$

197 where $x_{i}$ are the major oxides $\mathrm{MgO}, \mathrm{FeO}, \mathrm{CaO}, \mathrm{TiO}_{2}, \mathrm{MnO}, \mathrm{Al}_{2} \mathrm{O}_{3}, \mathrm{NiO}_{2}, \mathrm{SiO}_{2}$ and $\mathrm{H}_{2} \mathrm{O}$.

198 When serpentine was ablated we assumed $13 \mathrm{wt} \% \mathrm{H}_{2} \mathrm{O}$, otherwise it was set to 0 . Trace

199 element concentrations were then determined from equation (1) using $\mathrm{SiO}_{2}$

200 concentrations determined from equation (2). Analyses of magnetite always overlapped

201 with serpentine matrix due to the fine nature of those veins, so we used the determined

$202 \mathrm{SiO}_{2}$ of the composite spot as an internal standard. The validity of this method is shown

203 in Supplementary Table 2 by the good stoichiometry of the average measured serpentine

204 to the formula $(\mathrm{Mg}, \mathrm{Fe})_{3} \mathrm{Si}_{2} \mathrm{O}_{5}(\mathrm{OH})_{4}$ and in Table 2 by comparing the clinopyroxene

205 major element concentrations determined here against electron microprobe clinopyroxene

206 data for these samples reported elsewhere (Warren et al., 2009; Mallick et al., 2014;

207 Mallick et al., 2015). For $\mathrm{SiO}_{2}$, which we use as our LA-ICMPS internal standard, the

208 variance between the two methods is $\sim 6 \%$ relative, or less. Based on this and the

209 inherited uncertainty in assuming the water concentration of the serpentine at $13 \mathrm{wt} \%$, we

210 estimate that the in situ trace element concentrations of the serpentine are accurate to

211 within 10-15\% relative. Average trace element concentrations are reported in Table 3

212 and all individual spot analyses are reported in Supplementary Table 1. 


\section{3.2 Sequential Leaching Experiments.}

214 Interior pieces of the peridotites were powdered with an agate ball mill. The bulk

215 rock was digested for trace element and isotope analyses. A second fraction ( 1 gram)

216 was taken through a sequential leaching procedure following a modified technique after

217 Chester and Hughes (1967) shown schematically in Supplementary figure 2. The

218 leaching steps were: first, an $\mathrm{H}_{2} \mathrm{O}$ leach for removal of any readily exchangeable metals;

219 second, a buffered $(\mathrm{pH}=5)$ sodium acetate solution $(\mathrm{NaOAc})$ for the selective removal of

220 carbonates; third, a buffered $(\mathrm{pH}=4)$ hydroxylamine hydroxide $(\mathrm{HH})$ solution for the

221 preferential removal of $\mathrm{Fe}$-oxide and $\mathrm{Fe}$-oxyhydroxides and fourth, cold leach with $6 \mathrm{~N}$

$222 \mathrm{HCl}$ for the removal of surface bound trace elements at mineral grain boundaries and

223 removal of easily dissolvable mineral fractions (alteration). The leached residues were

224 also dissolved and an aliquot of each fraction was taken for trace element analyses. The

225 trace element and $\mathrm{Sr}, \mathrm{Nd}$ isotopes of the leachates and the residual rock were then

226 compared to those of the bulk (unleached) rock. See Supplementary text material for

227 additional details on the leaching protocol.

\section{3.3. Sr, Nd Isotopes}

229 We analyzed the bulk rock, the combined $\mathrm{NaOAc}$ and $\mathrm{HH}$ leachates, $6 \mathrm{~N} \mathrm{HCl}$

230 leachate, and the residual rock for $\mathrm{Sr}$, $\mathrm{Nd}$ isotopes. The clinopyroxene $\mathrm{Sr}$ and $\mathrm{Nd}$ isotope

231 compositions are taken from Mallick et al., (2014). Separation of REE from Sr was

232 performed using cation exchange resin (Eichrom 50W-X8). Sr was purified on micro-

233 columns with Sr-Spec resin. Nd was purified from the other REE on micro-columns with

234 LN spec resin. Sr and Nd isotope ratios were measured on a Thermo NEPTUNE MC-

235 ICPMS. ${ }^{87} \mathrm{Sr} /{ }^{86} \mathrm{Sr}$ and ${ }^{143} \mathrm{Nd} /{ }^{144} \mathrm{Nd}$ ratios are normalized for fractionation to ${ }^{86} \mathrm{Sr} /{ }^{88} \mathrm{Sr}=$ 
2360.1194 and ${ }^{146} \mathrm{Nd} /{ }^{144} \mathrm{Nd}=0.7219$, respectively. During these analyses the ${ }^{87} \mathrm{Sr} /{ }^{86} \mathrm{Sr}$ ratio

237 of the NISTSRM-987 was measured at $0.710306 \pm 17(2 \sigma, \mathrm{n}=7)$ and ${ }^{143} \mathrm{Nd} /{ }^{144} \mathrm{Nd}$ of

238 LaJolla at $0.511839 \pm 10(2 \sigma, \mathrm{n}=20)$, typical to other studies from our lab (Mazza et al.,

239 2014; Whalen et al., 2015). The isotope ratios are corrected for instrument bias to

$240{ }^{87} \mathrm{Sr} /{ }^{86} \mathrm{Sr}=0.710250$ for the NISTSRM-987 (Weis et al, 2005), and ${ }^{143} \mathrm{Nd} /{ }^{144} \mathrm{Nd}=0.511858$

241 for La Jolla (O’Nions et al., 1977).

$242 \quad 4.0$ Results

$243 \quad 4.1$ Major element compositions

244 Average major element data for primary and secondary (serpentine, iron oxides)

245 minerals are reported in Table 2. For sample VAN 7-78-36H we use the clinopyroxene

246 data reported in Mallick et al. (2014). In short the major element compositions of

247 clinopyroxene from these two locations (VAN7-78 and VAN7-85) display in general

248 modest variation considering the variability of cpx from other ridge locations. Based on

249 a somewhat larger dataset reported by Mallick et al. (2014) the VAN7-85 sample suites

250 are characterized by restricted and depleted character e.g., low $\mathrm{Na}_{2} \mathrm{O}(0.37-0.52$ wt. \%),

$251 \mathrm{TiO}_{2}(0.17-0.24$ wt.\%) content consistent with the harzburgitic composition. VAN7-78

252 clinopyroxene have $\mathrm{Na}_{2} \mathrm{O}$ content similar to VAN7-85 samples, but are characterized by

253 a high and large range of $\mathrm{TiO}_{2}(0.23$ to $0.53 \mathrm{wt} . \%)$ content, which seems consistent with

254 the presence of frequent plagioclase in VAN7-78 peridotites mineral assemblage. Further

255 details on the clinopyroxene major element systematics can be found in Mallick et al.

256 (2015) and are not further discussed here, as our focus is the trace element systematics

257 related to serpentinization. 
Olivine was variably altered, from cloudy partially serpentinized grains to

259 serpentine with variable extents of alteration based on the $\mathrm{MgO} / \mathrm{SiO}_{2}$ ratios acquired with

260 SEM-EDX at multiple spots of the sample. The serpentine stoichiometry from LA-

261 ICPMS serpentine analyses is $(\mathrm{Mg}+\mathrm{Fe}) / \mathrm{Si} \sim 1.3$ to 1.55 in cation moles and straddles the

262 ideal serpentine (lizardite) mineral stoichiometry of $(\mathrm{Mg}, \mathrm{Fe})_{3} \mathrm{Si}_{2} \mathrm{O}_{5}(\mathrm{OH})_{4}$ (see

263 Supplementary Table 2, e.g., Frost and Beard, 2007). Consistency of serpentine

264 stoichiometry was found among all serpentine phases despite the nature of the primary

265 minerals they are replacing (olivine, orthopyroxene). Serpentine after orthopyroxene was

266 found to have elevated concentrations of trace metals ( $\mathrm{Ti}, \mathrm{Sc}, \mathrm{Zr}$, REE, Hf) compared to

267 serpentine after olivine (see Supplementary Table 1), consistent with the higher partition

268 coefficients of these elements in orthopyroxene over olivine. We used these trace

269 element characteristics along with $(\mathrm{Mg}+\mathrm{Fe}) / \mathrm{Si}$ ratios and the $\mathrm{Al}$ concentrations to identify

270 the protolith mineral of the serpentine, i.e. olivine vs. orthopyroxene (Supplementary

271 Table 2) and to calculate the average serpentine after olivine in Tables 2 and 3. We did

272 not identify brucite $(\mathrm{Mg}, \mathrm{Fe}) \mathrm{OH}_{2}$ with the $\mathrm{SEM}$ analyses in any sample. We also

273 performed XRD analyses on samples VAN7-78-39 and VAN7-85-42 using a Shimadzu

274 LabX XRD-6000 (at USC) but again no brucite was identified. Nevertheless brucite may

275 still be present in minor and disseminated within the serpentine (e.g. Frost and Beard,

276 2007), which may explain some of the $(\mathrm{Mg}+\mathrm{Fe}) / \mathrm{Si}$ variance.

277 Orthopyroxene has $(\mathrm{Mg}+\mathrm{Fe}) / \mathrm{Si} \sim 0.9-1.1$ that straddles stoichiometric

278 orthopyroxene $(\mathrm{Mg}, \mathrm{Fe}) \mathrm{SiO}_{3}$ and co-varies strongly with the $\mathrm{Mg}$ content as a result of

279 partial overlap with serpentine or replacement by serpentine in some cases (Figure 1D). 
281 widespread in these rocks, typically as disseminated veinlets in the serpentine (Fig. 1A,

282 1B). Due to their small size compared to our laser beam size, the magnetite analyses

283 overlapped with the matrix (always serpentine), as can be seen by the significant $\mathrm{MgO}$

284 and $\mathrm{SiO}_{2}$ in their totals and the $\mathrm{Si} / \mathrm{Mg}$ cation ratios (Table 2). Nevertheless, as the signal

285 is dominated by the magnetite (spot analyses $\mathrm{FeO}_{(\mathrm{T})}>60 \mathrm{wt} \%$ ) these magnetite data are

286 informative in constraining the trace element systematics of these magnetite veins.

287 4.2. Trace element systematics of the bulk rock and minerals

$288 \quad$ 4.2.1 Bulk Rock

289 Bulk rock REE patterns for the 6 peridotites are shown in Figure 2. Both groups

290 of peridotites have roughly similar HREE concentrations that are lower than primitive

291 mantle (Fig. 2A), consistent with being residues of melt extraction at a mid oceanic ridge

292 setting. The VAN 7-78 samples have higher LREE/HREE ratios than the VAN 7-85

293 samples with concave up REE patterns from La to Dy. The VAN 7-85 samples have a

294 strongly depleted LREE to HREE pattern from Nd to Lu, but show a prominent negative

295 Ce anomaly relative to La and Pr. The extended bulk rock trace element patterns show

296 strong positive $\mathrm{U}, \mathrm{Pb}$ and $\mathrm{Sr}$ anomalies (Fig. 2B), as typically found in other abyssal

297 peridotites (Niu, 2004; Paulick et al., 2006; Delacour et al., 2008; Jöns et al., 2010,

298 Kodolányi et al., 2012; Deschamps et al., 2013), and usually attributed to interaction with

299 seawater. The higher concentrations in the LREE-MREE and Hf, Zr, Ti of the VAN 7-78

300 over the VAN 7-85 samples are consistent with the refertilized nature of the former (e.g.

301 Mallick et al., 2014; Mallick et al., 2015) as also identified in their clinopyroxene

302 concentrations (see below). 


\subsubsection{Clinopyroxene}

Clinopyroxene in the three VAN 7-85 peridotites and the VAN 7-78-39 show

305 strong LREE depletions over the HREE. Most importantly, they lack the large negative

306 Ce anomaly identified in the bulk rock patterns (compare Figs. 2A and 3). The VAN 7-

307 78-36H and VAN 7-78-41 clinopyroxenes show relative flatter REE patterns consistent

308 with refertilization by melt-rock reaction (Mallick et al., 2015).

309 Extended trace element patterns for the clinopyroxene show similar patterns for

310 both sample suites with enrichments in U over the LREE and Th, strong depletions in $\mathrm{Sr}$

311 and to a lesser extent $\mathrm{Zr}$, Hf, Ti over the adjacent REE (compare Figs $2 \mathrm{~B}$ and 4 ) and

312 unlike the bulk rock concentrations. Clinopyroxenes from VAN 7-78-36H and VAN 7-

313 78-41 show a flatter pattern with over two orders of magnitude higher LREE, Th and Ba

314 than the other samples, consistent with refertilization and also seen in their bulk rock

315 trace element systematics.

\section{$316 \quad$ 4.2.3 Orthopyroxene}

317 The orthopyroxene HREE concentrations are similar in the two rock suites and

318 roughly a factor of 4 lower than the corresponding clinopyroxene, generally consistent

319 with experimental partitioning data (e.g. Salters et al., 2002; McDade et al., 2003).

320 Orthopyroxenes in the VAN 7-78 samples have higher LREE contents than the VAN 7-

32185 samples, consistent with these enrichments in the bulk rock and clinopyroxene

322 systematics discussed above. The samples with the greatest LREE depletions display a

323 distinct uptick in La over Ce that is not observed in the corresponding clinopyroxene

324 (compare Figures. 2A and 3), and opposite to what is predicted from the partitioning

325 systematics where LREE become increasingly more incompatible in the pyroxenes with 
326 decreasing atomic number and increasing coordination size (Hauri et al., 1994; Wood and

327 Blundy, 1997; Salters et al., 2002; McDade et al., 2003).

328 The extended trace element patterns of the orthopyroxene are roughly similar for

329 the two suites with positive $\mathrm{U}$ and $\mathrm{Pb}$ spikes over the LREE and highly variable $\mathrm{Sr}$

330 concentrations. The positive $\mathrm{Hf}, \mathrm{Zr}$, Ti spikes compared to the REE is consistent with

331 higher partition of these elements over the adjacent REE in a compatibility diagram in

332 orthopyroxene (e.g. Salters et al., 2002, compare Figures 2B and 4)

\section{$333 \quad$ 4.2.4 Serpentine / matrix}

334 Serpentine concentrations (Fig. 3, 4) are variable and a significant part of their

335 variance depends on their proto-mineral (orthopyroxene or olivine). As discussed in

336 section 4.1 the proto-mineral of the serpentines were distinguished by their trace element

337 characteristics along with $(\mathrm{Mg}+\mathrm{Fe}) / \mathrm{Si}$ ratios and the $\mathrm{Al}$ concentrations. For the average

338 serpentine composition reported in Tables 2 and 3 only the serpentine after olivine was

339 used. Overall, the HREE concentrations of the serpentine after olivine are 10-20 times

340 lower than the corresponding clinopyroxene, roughly consistent with the partitioning of

341 these elements between olivine and clinopyroxene (e.g. Salters et al., 2002; McDade et

342 al., 2003) and where the LREE are depleted with respect to HREE. Serpentine after

343 orthopyroxene typically has HREE concentrations similar to 5 times lower than that of

344 fresh orthopyroxene while LREE concentrations are often 10-20 times greater with a

345 negative Ce anomaly (Fig. 3). Serpentine in the VAN 7-85 and VAN 7-78-39 samples

346 with the largest depletion in their LREE over HREE show characteristic negative Ce

347 anomalies compared to La and Pr, as also observed in the bulk rock trace element

348 systematics (compare Figures 2A and 3) but also have elevated LREE compared to the 
349 fresh primary mineral (Fig. 3). The extended trace element patterns for these serpentines

350 show strong positive $\mathrm{U}, \mathrm{Pb}$, and $\mathrm{Sr}$ anomalies together with negative anomalies in $\mathrm{Th}, \mathrm{Ce}$

351 and $\mathrm{Zr}$, mirroring those of the bulk rock trace element patterns (compare Figures 2B and

$3524)$.

353 Serpentines in samples VAN 7-78-36H and VAN 7-78-41 show flatter REE

354 patterns with higher LREE concentrations than the other samples and no obvious

355 negative Ce anomaly, also consistent with their bulk rock trace element systematics. The

356 extended trace element pattern for samples VAN 7-78-36H and VAN 7-78-41 is elevated

357 compared to the VAN 7-85 and VAN 7-78-39 samples, with positive anomalies for U,

$358 \mathrm{~Pb}$, and $\mathrm{Sr}$ but no distinct negative anomalies in $\mathrm{Zr}$ (compare Figs. 2B and 4).

\section{$359 \quad$ 4.2.5 Plagioclase}

360 Plagioclase was found in the VAN 7-78 samples, as veins generally smaller than

$361100 \mu \mathrm{m}$ in width. Laser ablation data of Plagioclase on samples VAN 7-78-36H and

362 VAN 7-78-41 was acquired on the largest minerals found. The REE pattern shows a

363 LREE enriched pattern with the distinct positive Eu anomaly typical of plagioclase. The

364 HREE concentrations are lower than the serpentine matrix, but the LREE are higher

365 (compare Figs. 3 and 5A). Extended trace element patterns show the strong positive $\mathrm{Sr}$

366 anomaly and higher Ba than the matrix serpentine, and characteristic large depletions in

367 the HFSE compared to the REE (compare Figures 4 and 5B).

\section{$368 \quad$ 4.2.6 Magnetite}

369 Magnetites in the VAN 7-78 samples have slight LREE depleted patterns with

370 small negative Ce anomalies. Their REE concentrations are roughly a factor of 5 lower

371 than the corresponding serpentine (compare Figs. 3 and 5C). In contrast, magnetite in 
372 sample VAN 7-85-42 has a flat REE pattern with up to 100 times higher LREE

373 concentrations than corresponding serpentine and again with a distinct negative $\mathrm{Ce}$

374 anomaly. The extended trace element patterns are quite variable, with strong positive U,

$375 \mathrm{~Pb}$, Sr spikes similar to serpentine concentrations (compare Figures 4 and 5D). The

376 HFSE are far more variable with both positive and negative Ti anomalies, but with a

377 dominant negative Th, Zr, and Hf anomalies, particularly pronounced in sample VAN 7-

378 85-42 with the high REE concentrations.

379 4.2.7 Modal Abundances and Bulk Rock Reconstruction Model

380 We used the average laser ablation mineral concentration data above to estimate

381 the modal abundance of the analyzed phases (Tables 2 and 3: spots used to determine

382 mineral concentration averages are identified in Supplementary Table 1). We then use

383 these modal abundances to reconstruct the bulk rock trace element composition and

384 compare in detail the measured vs. reconstructed trace element systematics. This

385 exercise, although somewhat circular, allows to better assess the main hosts for different

386 trace elements between primary and secondary phases. Mineral modes were determined

387 empirically by minimizing the average difference between modeled REE concentrations

388 and measured bulk rock REE patterns from solution chemistry. In order to avoid

389 spurious results we constrained the modal abundance to less than $2 \%$ modal magnetite

390 and plagioclase (where present), less than $10 \%$ clinopyroxene and a maximum serpentine

391 to orthopyroxene ratio of 30 . In cases of poor overall match, we attempted to fit the

392 HREE concentrations only. The determined modal abundances are reported on Table 2.

393 The best-fit reconstructions have 1 to $8 \%$ modal clinopyroxene, 3 to $25 \%$ orthopyroxene 
394 and up to $90 \%$ serpentine. Importantly, 0.5 to $2 \%$ modal magnetite was always found

395 necessary to best reconstruct the bulk rock concentration patterns (Figures 6 and 7).

396 The VAN 7-85 samples have the best overall fits between measured and

397 reconstructed compositions, with less than $15 \%$ average difference across the REE. This

398 suggests that our laser investigation identified all major REE reservoirs in the rock and

399 that the calculated modal abundances are reasonable (Table 2). The VAN 7-78 samples

400 were harder to fit, particularly for the LREE ( $\mathrm{La}, \mathrm{Ce}, \mathrm{Pr}, \mathrm{Nd}$ ) where the model

401 concentrations are significantly lower than the measured. The REE reconstruction is

402 particularly poor for sample VAN 7-78-41 as the HREE concentrations of clinopyroxene,

403 orthopyroxene and serpentine are higher than the measured bulk rock, leading to steeper

404 LREE/HREE ratios and crossing patterns for the modeled vs. measured bulk, and

405 unreasonably low clinopyroxene mode (negative). In this case it appears that there is

406 small-scale sample heterogeneity between the aliquot used for trace elements and for

407 laser and modal abundances cannot be reasonably estimated for this sample with this

408 method. For sample VAN 7-78-39, the most LREE depleted of this suite, the HREE can

409 be modeled well but the LREE fit is poor and highly sensitive to small changes of either

410 the clinopyroxene or plagioclase modes. The mismatch between measured and model

411 trace element concentrations in the VAN 7-78 samples can be explained if our laser

412 investigation "missed" a relatively LREE enriched component in these peridotites. As

413 these samples are considered refertilized by a LREE enriched melt (Mallick et al., 2014;

414 Mallick et al., 2015) perhaps there are components in the matrix related to this

415 refertilization (trapped melt along grain boundaries, or perhaps other minor phases) that

416 evaded our ablation investigation. 


\section{$417 \quad 4.3$ Trace element systematics of leachate experiments}

\section{$418 \quad$ 4.3.1 $\mathrm{H}_{2} \mathrm{O}$ Leach}

The $\mathrm{H}_{2} \mathrm{O}$ leachates have about 2 orders of magnitude lower REE concentrations

420 than the bulk rock, but with REE patterns that closely mimic that of the bulk rock

421 including Ce depletion in the VAN 7-85 samples (Fig. 8). The extended trace element

422 patterns show larger positive $\mathrm{U}$ and $\mathrm{Sr}$ anomalies than those of the bulk rock (Fig. 9),

423 with or without $\mathrm{Pb}$ spikes (VAN 7-85-42, 85-47). These large U and Sr enrichments in

424 the $\mathrm{H}_{2} \mathrm{O}$ leachates closely resemble that of average seawater (Fig. 9, lower right hand

425 corner)

\section{$426 \quad$ 4.3.2 Na-Acetate leach}

427 The NaOAc leach REE pattern mirrors that of the bulk rock for all samples. The

428 VAN 7-78 samples have concave up patterns with only a slight negative Ce anomaly and

429 the VAN 7-85 samples have a distinct negative Ce anomaly. Overall, the REE

430 concentrations are roughly a factor of 20 lower than the bulk rock (Fig. 8). The extended

431 trace element patterns again show strong positive anomalies for $\mathrm{Sr}$ and $\mathrm{U}$, although the $\mathrm{U}$

432 enrichment is proportionally greater than the Sr compared to the bulk rock, suggesting

433 stronger $\mathrm{U}$ mobilization in this leachate (Fig. 9). Characteristic is also the greater $\mathrm{Ba} / \mathrm{Th}$

434 than all other fractions and the bulk rock, which we speculate is related to the affinity of

435 Ba to substitute $\mathrm{Ca}$ in carbonate. Importantly, all $\mathrm{NaOAc}$ leachate patterns overall

436 resemble that of seawater but with higher HFSE depletions relative to the REE than

437 average seawater. This implies that the phase mobilized by this leachate carried REE, Sr

438 and U preferentially over the HFSE. 


\subsubsection{Hydroxylamine Hydroxide Leach}

The HH leach pattern generally mirrors the REE pattern of the bulk rock with

441 concave up patterns for the VAN 7-78 samples and LREE depleted patterns with a

442 distinct negative Ce anomaly in the VAN 7-85 samples. Importantly, the HH leachate

443 has higher LREE/HREE ratios that NaOAc leachate in the VAN 7-85 samples as seen by

444 their crossing REE patterns (Fig. 8). The extended trace element patterns show distinct

445 positive $\mathrm{Sr}, \mathrm{Pb}$ and $\mathrm{U}$ anomalies with pronounced negative $\mathrm{Ti}, \mathrm{Zr}$, and $\mathrm{Hf}$ anomalies for

446 all samples (Fig. 9). This is evidence for strong REE-HFSE fractionation during Fe-

447 oxide and magnetite precipitation.

\section{$448 \quad$ 4.3.4 6N HCl Leach}

449 The $6 \mathrm{~N} \mathrm{HCl}$ leachate REE are 3-5 times lower in concentration than the bulk

450 rock, but with higher LREE/HREE than the bulk rock (Fig. 8). The extended trace

451 element patterns show the prominent positive U spike, as in the other leachates, while the

452 Sr spike is now largely absent (Fig. 9). Negative Zr, Hf, and Th anomalies relative to the

453 REE persist, while Ti depletions that were observed in the other leachates are absent.

\section{$454 \quad$ 4.3.5 Residual Rock}

455 The residual rock after all leaching steps has a REE pattern that parallels the 456 original bulk rock pattern at 2 to 4 times lower concentration (Fig. 8). The extended trace

457 element patterns lack the $\mathrm{Sr}$ peak observed in the bulk and the $\mathrm{H}_{2} \mathrm{O}, \mathrm{NaOAc}, \mathrm{HH}$

458 leachates. The $\mathrm{U}$ enrichment is now also lower and in some cases small positive $\mathrm{Zr}$ and

459 Hf peaks are present, which is consistent with the presence of residual orthopyroxene 460 (Fig. 9). 
Overall, with sequential leaching there is progressive removal of the fluid mobile

462 elements ( $\mathrm{Ba}, \mathrm{Sr}$, Th and $\mathrm{U}$ ) with $45-98 \%$ of the bulk rock budget mobilized by leaching

463 (Supplementary Figure 3). Between 20\% and 60\% of the REE budget are mobilized

464 from the bulk rock during total leaching while only up to $10 \%$ of the $\mathrm{Hf}$ and $\mathrm{Zr}$ bulk rock

465 budget was been mobilized (Supplementary Figure 3). The percent distribution of trace

466 elements in the different leachate fractions is show schematically in the Supplementary

467 Figures 3. The sum of trace element concentrations in the leachate and residual fractions

468 matches the bulk rock well, confirming that all elemental reservoirs have been accounted

469 for during the sequential leaching (Figure 10).

470 4.4. Sr and Nd isotope data

$471 \quad{ }^{87} \mathrm{Sr} /{ }^{86} \mathrm{Sr}$ and $\varepsilon_{\mathrm{Nd}}$ values for the bulk rock and leachates are reported in Table 5 and 472 plotted on a Sr-Nd anticorrelation isotope diagram (Figure 11) along with the

473 clinopyroxene compositions from these samples from Mallick et al., (2014). The

474 clinopyroxenes from these peridotites appear to have retained their magmatic mantle

475 signature and plot within the MORB field (Warren et al., 2009; Mallick et al., 2014). In

476 contrast, the bulk rock ${ }^{87} \mathrm{Sr} /{ }^{86} \mathrm{Sr}$ and $\varepsilon_{\mathrm{Nd}}$ data are shifted to higher and lower values

477 respectively than clinopyroxene. The more depleted VAN 7-85 samples show a shift in

478 both ${ }^{87} \mathrm{Sr} /{ }^{86} \mathrm{Sr}$ and $\varepsilon_{\mathrm{Nd}}$ compared to their clinopyroxene, with their bulk rock ${ }^{87} \mathrm{Sr} /{ }^{86} \mathrm{Sr}$

479 essentially identical to that of modern seawater $\left({ }^{87} \mathrm{Sr} /{ }^{86} \mathrm{Sr}=0.70916\right)$, and $\varepsilon_{\mathrm{Nd}}$ up to 8

480 units lower than clinopyroxene (e.g., sample VAN 7-85-43, Table 5). The refertilized

481 VAN 7-78 samples show a shift in ${ }^{87} \mathrm{Sr} /{ }^{86} \mathrm{Sr}$ towards seawater but not as extreme as the

482 VAN 7-85 samples, and with little change in $\varepsilon_{\mathrm{Nd}}$. 
484 both sample suites. This shift in $\mathrm{Sr}$ isotopes in serpentinized peridotites during leaching 485 is also consistent with the observations of Harvey et al., (2014) on serpentinites from the $48615^{\circ} 20^{`} \mathrm{~N}$ fracture zone, Mid Atlantic ridge. For samples VAN 7-85-47 and VAN 7-85-

48742 , their ${ }^{87} \mathrm{Sr} /{ }^{86} \mathrm{Sr}$ ratios increased after leaching to values higher than seawater. This 488 peculiar observation was previously described as "orphan" ${ }^{87} \mathrm{Sr}$, possibly the result of 489 incorporation of Sr of crustal origin as clays within the rock structure, which was not 490 removed during leaching (Snow et al., 1993) and our experiments seem to confirm such a 491 component in these peridotites.

492 The combined NaOAc and $\mathrm{HH}$ leachates invariably have higher ${ }^{87} \mathrm{Sr} /{ }^{86} \mathrm{Sr}$ and 493 lower $\varepsilon_{\mathrm{Nd}}$ than the bulk rock (with $\varepsilon_{\mathrm{Nd}}$ as low as - 2.8 for Van 7-85-47; Table 5). Even for 494 the VAN 7-78 samples that show little change in the bulk rock vs. clinopyroxene $\mathrm{Nd}$ 495 isotopes, the $\mathrm{NaOAc}+\mathrm{HH}$ leachate has lower $\varepsilon_{\mathrm{Nd}}$ than the bulk rock. The $6 \mathrm{~N} \mathrm{HCl}$

496 leachates have higher $\varepsilon_{\mathrm{Nd}}$ than the $\mathrm{NaOAc}+\mathrm{HH}$ leachates, approaching the leached rock 497 composition. This indicates that the enriched $\mathrm{Nd}$ isotopes are preferentially concentrated 498 in a relatively easily mobile phase, yet some persist in the leached bulk rock.

\section{$499 \quad 5.0$ Discussion}

500 The key observations from the data presented above are summarized as follows:

$501 \quad$ 1. $\mathrm{U}, \mathrm{Sr}, \mathrm{Ba}, \mathrm{Pb}$ positive spikes and negative $\mathrm{Ce}$ anomalies are observed in situ in 502 the serpentine fraction of altered peridotites, and in magnetite associated with $503 \quad$ veins within serpentine. 
2. These anomalies are also observed both in the easily mobile phases as demonstrated by the leaching experiments, suggesting that they are dominantly hosted in secondary phases.

3. The lack of negative Ce anomalies in the relic clinopyroxene is evidence for disequilibrium reactions in the serpentinized peridotites where the negative $\mathrm{Ce}$ anomalies are imprinted to the bulk rock at lower temperatures than magmatic conditions.

4. ${ }^{87} \mathrm{Sr} /{ }^{86} \mathrm{Sr}$ and $\varepsilon_{\mathrm{Nd}}$ isotopes in the bulk rock and leached fractions of these peridotites are higher and lower, respectively, than their clinopyroxene and approach the composition of seawater, linking directly the observed $\mathrm{U}, \mathrm{Sr}, \mathrm{Pb}$ spikes and negative $\mathrm{Ce}$ concentration anomalies in these fractions to seawater input. magnitude of $\mathrm{Ce}$ anomalies in the serpentine are more evident in the depleted peridotites from the VAN 7-85 dredge than the refertilized peridotites from the VAN 7-78 dredge.

6. The combination of radiogenic $\mathrm{Sr}$ and unradiogenic $\mathrm{Nd}$ isotopes that approach

526 mobile elements seen in serpentinized peridotites (B, Cl, Sr, Rb, Cs, Li, C, S; e.g., 
527 Scambeluri et al., 2004; Alt et al., 2013; Deschamps et a., 2013, for detailed literature

528 reviews), the REE systematics of peridotites can also be affected by seawater interaction.

\section{$529 \quad 5.1$ Nd-isotope mass balance between peridotite and seawater}

530 Assuming that the shift in bulk rock Nd isotopes in these peridotites, from their

531 mantle isotope composition recorded in the clinopyroxene towards more enriched

532 compositions, is entirely due to seawater interaction, we can determine the proportion of

533 the bulk rock Nd that is seawater-derived. This is calculated by mass balance using the

534 Nd-isotope compositions of clinopyroxene (i.e., the mantle value) and seawater as end

535 members, and that of the measured bulk rock as the mixture (eq. 3).

$\% N d_{S W}=\left({ }^{143} N d l^{144} N d_{B R}{ }^{-}{ }^{143} N d l^{144} N d_{C p x} \mathcal{J}\left({ }^{143} N d l^{144} N d_{S W^{-}}{ }^{143} N d l^{144} N d_{C p x}\right)\right.$

539 where ${ }^{143} N d l^{I 44} N d_{B R}$ is the measured bulk rock ${ }^{143} \mathrm{Nd} /{ }^{144} \mathrm{Nd},{ }^{143} \mathrm{Nd} /{ }^{144} N d_{C p x}$ is the

540 measured clinopyroxene and ${ }^{143} N d /{ }^{144} N d_{S W}$ is the measured ${ }^{143} \mathrm{Nd} /{ }^{144} \mathrm{Nd}$ of average

541 seawater from near the SWIR (see Table 5: Stichel et al., 2012). The calculated range of

542 seawater-derived Nd ranges from $3 \%$ for VAN 7-78-36H to $31 \%$ for VAN 7-85-43 of the

543 bulk rock Nd budget (Table 5). The more depleted VAN 7-85-dredge samples record a

544 greater proportion of seawater-derived $\mathrm{Nd}$ than the refertilized 78-dedge samples. To a

545 first approximation, this implies that depleted peridotites with low REE contents are more

546 susceptible to a seawater influence and changes in their REE budget than more fertile 547 ones.

548 While this calculation is informative in terms of the impact of serpentinization on

549 the bulk rock Nd budget, it does not reveal whether there was REE exchange between 
550 seawater and peridotite or seawater addition, or how the negative Ce anomaly developed.

551 In the following we discuss: 1) the origin of the negative Ce anomaly in the bulk rock and

552 serpentine, 2) the evidence for LREE addition within the secondary mineralogy, and 3)

553 whether serpentinization acts as a sink for REE from seawater, or whether REE are

554 exchanged between the ocean and the peridotite.

\section{$555 \quad 5.2$ LREE addition or exchange?}

\section{$556 \quad$ 5.2.1 Origin of the negative Ce anomalies}

557 One possible explanation for the negative $\mathrm{Ce}$ anomalies is preferential

558 mobilization of Ce from the rock while all other REE are retained. In principle, this is

559 unlikely as we are not aware of any process that will make Ce more mobile, or soluble,

560 than the other LREE. Instead, $\mathrm{Ce}^{+3}$ can be preferentially oxidized to $\mathrm{Ce}^{+4}$, which is less

561 soluble and less mobile than the other REE. We can nevertheless test this hypothesis by

562 calculating the hypothetical magmatic concentrations of the unaltered orthopyroxene and

563 olivine in these peridotites using the REE concentrations of the fresh clinopyroxene and

564 published mineral-mineral partition coefficients values (e.g. McDade et al., 2003; Bizimis

565 et al., 2004; Kelemen et al., 2004; Sun and Liang, 2014; see Supplementary Table 3).

566 From these concentrations and the modal abundances determined by the laser-ablation

567 reconstruction (section 4.2.7) and assuming that the serpentine modal abundance equals

568 that of the precursor olivine we reconstruct the REE concentrations of the primary

569 peridotite (Fig. 12). If preferential mobilization of Ce out of the rock was the reason for

570 the Ce depletions, then the reconstructed LREE concentrations (except Ce) should match

571 that of the measured bulk rock. We test this on the more depleted VAN 7-85 samples, as

572 those have simpler REE patterns and are less affected by melt refertilization. For the 
573 VAN 7-85 samples, the HREE concentrations between measured and calculated bulk

574 rocks match well, suggesting that the calculated modal abundances are reasonable

575 (despite the volume increase of serpentine relative to olivine). Yet, the calculated LREE

576 are lower than the measured bulk rock, with no Ce anomaly. As the partition coefficient

577 between pyroxenes and olivine lack a Ce anomaly, even small errors in the modal

578 abundances of any of these minerals cannot account for the Ce anomaly. These data point

579 to addition of (at least) La and Pr but not Ce to the rock, rather than selective Ce

580 mobilization out of the rock.

$581 \quad \mathrm{U}$ and Th are both highly incompatible in the peridotite mineralogy (e.g., Salters

582 et al., 2002), so their relative fractionation in the abyssal peridotites (Fig. 2B) is largely

583 controlled by a strong $\mathrm{U}$ addition that has been attributed to seawater (e.g. Niu, 2004;

584 Deschamps et al., 2013) as U is generally a conservative element in seawater (Chen et al.,

585 1986). With increasing $\mathrm{U} / \mathrm{Th}$ ratio and increasing seawater influence on the bulk rock $\mathrm{U}$

586 budget, the magnitude of the Ce anomaly increases (Fig. 13). This indirectly implies that

587 the La and Pr addition over Ce must also be controlled to some extend by seawater,

588 which has a distinct negative $\mathrm{Ce}$ anomaly due to oxidation of $\mathrm{Ce}^{3+}$ to $\mathrm{Ce}^{+4}$ and its

589 preferential scavenging over the other REE (Elderfield et al, 1982; Piepgras et al, 1992;

590 Alibo and Nozaki, 1999). As this U/Th vs. Ce anomaly correlation is dominant feature in

591 the global abyssal peridotite compositions (Fig. 13), it implies that the process of LREE

592 addition by seawater might be also wide spread in abyssal peridotites in general and not

593 only confined in the SWIR peridotites. 


\section{$594 \quad 5.2 .2 \mathrm{Nd}$ isotopes and LREE addition}

595 Using the same bulk rock reconstruction from clinopyroxene as above (Section

596 5.2.1), we compare the calculated $\mathrm{Nd}$ concentration of the primary peridotite $\left(\mathrm{Nd}_{\mathrm{PR}}\right)$ to

597 that of the measured bulk rock $\left(\mathrm{Nd}_{\mathrm{BR}}\right)$, their difference being potentially an estimate of

598 the amount of $\mathrm{Nd}$ that was added to the rock during serpentinization. In this calculation

599 the amount of added $\mathrm{Nd}$ to the $\mathrm{Nd}_{\mathrm{PR}}$ here ranges from $17 \%$ to $70 \%$. For samples VAN 7-

$60085-42$, and VAN 7-85-43 there is a striking similarity ( $<5 \%$ difference) between the

601 excess Nd calculated from the measured vs. modeled bulk rock, and the seawater-derived

$602 \mathrm{Nd}$ from the Nd-isotope mass balance approach (Table 6). This implies that addition of

603 seawater-derived $\mathrm{Nd}$ alone can reasonably account for the unradiogenic Nd isotopes and

604 the excess Nd.in these rocks.

605 For the VAN 7-78 samples, we find greater amount of excess Nd in the bulk rock

606 than the calculated seawater-derived Nd from the isotope mass balance. This discrepancy

607 can be explained by transient metasomatism of the VAN 7-78 samples by a melt prior to

608 serpentinization. If the infiltrating melt did not equilibrate with clinopyroxene, then the

609 clinopyroxene concentrations will not be representative of the bulk rock and will lead to

610 lower calculated bulk rock Nd concentrations than those measured. In this case, the

611 amount of seawater-derived $\mathrm{Nd}$ can best be calculated from the isotope mass balance,

612 assuming that the infiltrating melt had a similar (i.e., relatively radiogenic) Nd isotopic

613 composition to the primary clinopyroxene. The studies of Mallick et al., (2014) and

614 Mallick et al., (2015) have shown that clinopyroxene in these peridotites have similar $\mathrm{Nd}$

615 and $\mathrm{Hf}$ isotope compositions as their proximal lavas, providing support for this scenario. 
A key observation is that magnetite has negative $\mathrm{Ce}$ anomalies, as does the

618 serpentine (Figs. 3, 5C). Magnetite also has flatter REE patterns than those observed in

619 both the primary and secondary silicate minerals and similar to seawater pattern.

620 Kodolányi et al. (2012) made similar observations in forearc serpentinites, where

621 serpentine + magnetite veins have higher LREE contents than serpentine alone. The

622 presence of an Fe-oxide phase with flat REE patterns and Ce-anomaly is also inferred by

623 the strong negative $\mathrm{Ce}$ anomalies in the HH leachates (Fig. 8). In the VAN-7-85-42 and

624 VAN-7-85-43 samples the HH leachates have flatter REE patterns and larger Ce-

625 anomalies than their bulk rock (Fig. 8). This indicates that a portion of the LREE bulk

626 rock budget (except $\mathrm{Ce}$ ) is hosted in the secondary phases, consistent with both the REE

627 modeling (section 5.2.1) and the Nd isotopes (section 5.2.2) arguments above. As we

628 discussed earlier (Section 2), the presence of magnetite within serpentine veins and away

629 from relic olivine is explained by high fluid flux during the main stage of serpentinization

630 (Beard et al., 2009). The petrologic observation for high fluid and the Ce anomalies in

631 magnetite imply that the source of these LREE enrichments is likely seawater-derived

632 fluid.

633 In contrast to the LREE element enrichments, negative $\mathrm{Zr}$ and $\mathrm{Hf}$ anomalies in

634 both the magnetite (Fig. 5D) and the HH leachate fractions (Fig. 9) compared to the REE

635 implies that the HFSE budget is less sensitive to serpentinization than the REE and must

636 be dominated by the silicate minerals in the protolith. This conclusion is further

637 supported by comparing the bulk rock and leachate fractions $\mathrm{Hf}$ vs. Ti to that of $\mathrm{Nd}$ vs. Ti

638 concentrations (Fig. 14). Hf and Ti are coupled and show a tight correlation, where as 
639 the $\mathrm{NaOAc}+\mathrm{HH}$ and the $6 \mathrm{~N} \mathrm{HCl}$ leachates have preferential enrichment for the $\mathrm{REE}$

640 over Ti with nearly 2 orders higher $\mathrm{Nd}$ concentrations for a given Ti (Fig. 14). Therefore

$641 \mathrm{Nd}$ is enriched in the easily mobilized phases, but not Hf. This supports previous

642 inferences that HFSE are a more faithful recorder of bulk rock magmatic processes (e.g.

643 Niu, 2004; Lapen et al., 2005; Bizimis et al., 2007; Stracke et al., 2011) than LREE in

644 peridotites. In addition to those studies however, here we present strong evidence that

645 serpentinization may also be responsible for the decoupling of LREE from the HFSE in

646 serpentinized abyssal peridotites.

\section{$647 \quad$ 5.2.4 Nd Isotopic disequilibrium within the peridotites}

648 The above evidence points to addition of a seawater-derived LREE component to

649 peridotites during serpentinization. It is unclear however whether the REE hosted within

650 the secondary phases (i.e., those mobilized from the $\mathrm{NaOAc}$ and $\mathrm{HH}$ ) are exclusively

651 from seawater or are a mixture of both seawater and of primary magmatic origin, that

652 were mobilized during alteration. Insight on this can be gained by the $\mathrm{Nd}$ isotope

653 compositions of the leachate and bulk rock fractions. For our samples, Sr is less useful in

654 deciphering rock vs. seawater contributions, as the leachate $\mathrm{Sr}$ isotope composition is

655 dominated by a seawater signal that does not vary significantly (Fig. 11).

656 Figure 11 compares the $\mathrm{Nd}$ and $\mathrm{Sr}$ isotope composition of the clinopyroxene (i.e.,

657 representing the primary mantle signature) with that of the bulk rock, the combined

$658 \mathrm{NaOAc}+\mathrm{HH}$ leachates, the $6 \mathrm{~N} \mathrm{HCl}$ leachate, and the residual rock after leaching. The

659 leachate $\mathrm{NaOAc}+\mathrm{HH}$ fractions have highly radiogenic seawater-like ${ }^{87} \mathrm{Sr} /{ }^{86} \mathrm{Sr}$ and lower

$660 \varepsilon \mathrm{Nd}$ than the bulk rocks, up to the highly unradiogenic value of $\varepsilon \mathrm{Nd}=-2.8$ for sample

661 VAN-7-85-47. Despite their unradiogenic values, these leachate fractions do not have a 
662 pure seawater $\mathrm{Nd}$ isotope signature $\left(\varepsilon_{\mathrm{Nd}} \sim-9.7\right)$, but rather a mixture of rock and seawater

663 composition. This implies that the Nd budget (and by inference the other LREE, besides

$664 \mathrm{Ce}$ ) in the secondary phases is not exclusively derived from seawater, but some of the

665 LREE are redistributed from the primary minerals to the alteration phases. This inference

666 is similar to that of Berndt et al., (1988) for Sr, where during hydrothermal alteration of

667 mid ocean ridge basalts, $\mathrm{Sr}$ is thought to be released from the primary rock and then

668 reincorporated in the alteration phases. Here we infer that the process of release and re-

669 incorporation likely takes place during serpentinization. Finally, the leached rock Nd-Sr

670 isotope compositions plot invariably between that of the clinopyroxene and the bulk rock

671 (Fig. 11), indicating that the seawater signature is pervasive within the residual silicate

672 fractions, and which probably include significant amounts of secondary serpentine,

673 although we cannot directly confirm this by the solution chemistry.

\section{$674 \quad 6.0$ Summary and Implications}

675 The Nd isotope data reveals strong isotopic disequilibrium in the various fractions

676 of these serpentinized peridotites, with compositions approaching seawater in the

677 secondary phases, pervasive alteration in the silicates, but preservation of the mantle

678 values in the clinopyroxene (and possibly orthopyroxene; Warren et al, 2009). Combined

679 with the enrichments in LREE along with the fluid mobile elements like $\mathrm{Ba}, \mathrm{U}, \mathrm{Sr}$, and

$680 \mathrm{~Pb}$ in the serpentine and secondary minerals, we conclude that these data provide strong

681 evidence LREE addition to the peridotite during serpentinization, and where the

682 precipitation of secondary phases, like magnetite, appears to play a significant role in

683 hosting the added LREE budget. Note that our data cannot easily constrain any HREE

684 addition that might also be taking place, due to the higher HREE concentrations in all 
685 primary silicate minerals over LREE, and the relatively flatter REE pattern of seawater

686 compared to those silicates, making LREE addition from seawater more prevalent and

687 obvious than HREE addition. We also emphasize that these rocks still preserve relic high

688 temperature mineral phases and as such they are not completely serpentinized.

\section{6.1 Water / rock ratio modeling}

690 The Sr-Nd isotope systematics of serpentinized peridotites have been used to

691 assess the integrated water/rock (W/R) ratio during serpentinization (e.g. Snow et al.,

692 1994; Delacour et al., 2008), a key parameter that allows to place constrains on $\mathrm{pH}$,

693 hydrogen generation, seawater-rock exchange as well as heat generation in hydrothermal

694 systems (e.g. Foustoukos et al., 2008). These calculations typically assume either closed

695 (bulk exchange) or open (incremental reaction) system water/rock reaction (see Delacour

696 et al., 2008 for details in the equations used here), Sr and Nd concentrations of the end

697 member fluid and rock that remain unchanged during reaction, and that the fluid and rock

698 are in equilibrium (e.g. Delacour et al., 2008). Indeed, if rock or fluid concentrations are

699 also free variables, these types of calculations cannot be solved explicitly and would

700 require a range of solutions for a range of compositions. The isotopic disequilibrium

701 between the different parts of these serpentinized peridotites (Fig. 11) and the preferential

702 addition of LREE in the alteration phases shown here, raise questions as to the validity of

703 the assumptions used in those calculations, and to the calculated water / rock ratios. In

704 light of these data, we explore the results of these W/R calculations on these peridotites,

705 assuming either the bulk rock or parts of the bulk rock (effectively bulk peridotite minus

706 clinopyroxene) reacted with seawater. Compared to other literature efforts, here we

707 know explicitly the primary magmatic isotopic composition of each sample from the 
708 clinopyroxene $\mathrm{Sr}$ and $\mathrm{Nd}$ isotopes, as well as the bulk rock $\mathrm{Sr}$ and $\mathrm{Nd}$ concentrations

709 which to a first approximation we take to represent the protolith. In the VAN 7-78

710 samples $\varepsilon_{\mathrm{Nd}}$ varies less than half $\varepsilon_{\mathrm{Nd}}$ unit and do not provide enough resolution to use the

$711 \varepsilon_{\mathrm{Nd}}$ as a tracer of $\mathrm{W} / \mathrm{R}$ ratios for these samples. As the $\mathrm{Nd}$ isotopic composition of global

712 seawater varies in the different ocean basins (e.g., Piepgras et al., 1979), we use seawater

$713 \mathrm{Nd}$ isotope and concentration data from that available closest to the South West Indian

714 ridge (Stichel et al., 2012).

715 From the ${ }^{87} \mathrm{Sr} /{ }^{86} \mathrm{Sr}$ ratios of the bulk peridotites and using either open or closed

716 system water / rock reactions equations (Delacour et al., 2008) we calculate a W/R ratio

717 for the VAN 7-78 samples in the range of $\sim 0.6-40$. For the VAN 7-85 samples using

718 the Nd-isotopes we calculate a range of $\sim 1070$ - 8500 (Table 6). Due to the low W/R

719 determined in the VAN 7-78 samples and no variability in the $\mathrm{Nd}$ concentrations, and our

720 primary focus being on potential LREE addition to the samples we will only focus on the

721 VAN 7-85 samples in the following discussion.

722 As the relic clinopyroxene has retained its mantle value concentration and isotope

723 composition, we can assume that only the $\mathrm{Nd}$ in bulk rock minus the $\mathrm{Nd}$ in the

724 clinopyroxene exchanged with the seawater during serpentinization. We calculate the $\mathrm{Nd}$

725 concentration of the orthopyroxene + olivine fraction of the rock by subtracting the

726 amount of Nd locked in the clinopyroxene, using the clinopyroxene modal abundance

727 from the modeling above and its measured concentration (Table 3). We assume that the

728 primary peridotite orthopyroxene + olivine fraction must have had the same Nd isotope

729 composition as the clinopyroxene, as these rocks were until very recently under high

730 temperature conditions in the upper mantle (1 to $2 \mathrm{My}$; Warren et al., 2009) and this is 
731 not enough time for significant (within one $\varepsilon_{\square \square}$ unit) change in Nd isotopes. We then

732 calculate the Nd isotope composition of the "altered" orthopyroxene + olivine rock by

733 subtracting the amount of radiogenic Nd locked in the clinopyroxene from the bulk rock

734 Nd budget (Table 6). In every case, the new water / rock ratio (without the

735 clinopyroxene) is only marginally higher in all samples except VAN 7-85-43 which

736 doubled from $\sim 8000$ to $\sim 17800$ for a closed system (Table 6) and $\sim 6500$ to 9200 for open

737 system. This is due to a large proportion of the bulk rock Nd residing in the

738 clinopyroxene, which results in highly unradiogenic $\mathrm{Nd}$ in the orthopyroxene + olivine

739 fraction and high $\mathrm{W} / \mathrm{R}$ ratios.

$740 \quad$ Note that if an average depleted mantle $\mathrm{Nd}$ concentration is assumed (e.g., 0.7

741 ppm Salters and Stracke, 2004; 0.48 ppm, Workman and Hart, 2005) for the peridotite

742 protoliths, the calculated W/R ratios would increase by at least ten-fold, to over 170,000.

743 This is because these peridotites have far lower bulk rock Nd concentrations than

744 depleted or primitive mantle (Table 2), requiring less reaction (by mass) with seawater to

745 change their Nd isotope composition. This explains why our calculated W/ R ratios are at

746 least an order of magnitude lower than those reported by Delacour et al. (2008) for

747 serpentinites from the Atlantis Massif, despite those samples having similar Nd isotopes

748 to the SWIR peridotites reported here. This demonstrates the need to use the actual

749 peridotite concentrations to more accurately assess the W/R ratios from radiogenic

750 isotopes.

751 An alternative method to estimate W/R is to assume that the proportion of

752 seawater-derived Nd in the bulk rock (Section 5.2) originated by complete scavenging of

$753 \mathrm{Nd}$ from the seawater / fluid to the rock during serpentinization. Qualitatively this is 
754 consistent with the high reactivity of REE for mineral surfaces e.g., adsorption of REE on

755 marine particulates (De Baar et al., 1985a; De Baar et al., 1985b; Elderfield et al., 1990;

756 Erel and Morgan, 1991; Sholkovitz et al., 1994), aquifer sands (Duncan and Shaw, 2003;

757 Tang and Johannesson, 2005), mineral surfaces (variety of surface types, Byrne and Kim,

758 1990; silica beads, Schijf and Marshall, 2011; clays, Coppin et al, 2002; Fe-hydroxides

759 Quinn et al., 2006a; 2006b; 2007) and organic macromolecules (Sonke and Salters, 2006;

760 Stern et al., 2007; Stern et al., 2014) as well as our own experiments on olivine reacting

761 with seawater (Frisby et al., 2011; 2013). Assuming a closed system reaction, the relative

762 mass of seawater required to react with the peridotite ranges from 1000-5400, lower but

763 remarkably similar to the W/R ratios by Nd isotope exchange calculated above using the

764 measured bulk rock concentrations. These calculations are again consistent with $\mathrm{Nd}$

765 addition rather than exchange during serpentinization. We emphasize that the sensitivity

766 of the Nd-isotopes to infer water-rock ratios also depends on the $\mathrm{Nd}$ concentration and

767 therefore fertility of the protolith. Depleted and non-refertilized peridotites with low $\mathrm{Nd}$

768 concentrations will be more sensitive to change in their LREE concentrations and $\mathrm{Nd}$

769 isotopes than fertile or metasomatized ones. In other words, it is more likely that low

770 water rock ratios will be evidenced in depleted samples, while for fertile samples higher

771 water rock ratios are needed to shift the Nd isotope enough to be resolved. Additional

772 detailed analyses of this kind are needed to assess the effects of increasing degrees of

773 serpentinization on the REE elements of peridotites of variable initial composition.

\section{$774 \quad 6.2$ REE sink and impact on mantle reservoirs}

775 It has been suggested that the bulk rock REE systematics of serpentinized

776 peridotites are controlled by depletion and melt addition (Niu, 2004), or redistribution 
777 and reequilibration during serpentinization (Allen and Seyfried, 2003; Deschamps et al.,

778 2012; Deschamps et al., 2013; Lafay et al., 2013). Here, we further postulate that

779 significant addition of LREE also occurs during serpentinization of peridotites. Such

780 preferential addition of LREE will fractionate both the REE and HFSE/REE systematics

781 in the serpentinized peridotites, leading to lower $\mathrm{Sm} / \mathrm{Nd}$ (and possibly higher $\mathrm{Lu} / \mathrm{Hf}$ ratios

782 if HREE are also being significantly added) than unaltered peridotites. Subduction of

783 serpentinized oceanic lithosphere is thought as a key mechanism of transferring water and

784 fluid mobile elements (e.g. As, Sb, B, Li, Cs, Pb, U, Ba, Sr) into the mantle wedge

785 beneath arc systems (Tatsumi et al., 1986; Kessel et al., 2005; Kessel et al., 2015; Cannat

786 et al., 1995; Carlson, 2001; Mével, 2003; Scambelluri et al., 2004; Savov et al., 2007,

787 Cannat et al., 2010; Deschamps et al., 2011). The limited available experimental data

788 shows that during dehydration melting of peridotite (Tatsumi et al., 1986; Kessel et al.,

789 2005; Spandler et al., 2014; Kessel et al., 2015), the LREE will preferentially partition to

790 the fluid/melt over the HREE. The excess LREE in serpentinized peridotites shown here

791 coupled with their preferential mobility could then result in a high LREE/HREE and

792 possibly high REE/HFSE ratio flux from the serpentinized peridotite to the mantle wedge

793 during dehydration melting, along with the fluid mobile elements.

794 Alternatively, if REE are retained within the serpentinized peridotite, past the

795 subduction factory and into the upper mantle, the fractionated $\mathrm{Sm} / \mathrm{Nd}$ and possibly $\mathrm{Lu} / \mathrm{Hf}$

796 ratios will persist in the peridotite leading to decoupled $\mathrm{Nd}$ and $\mathrm{Hf}$ isotope systematics in

797 the recycled altered lithosphere over time. Lower $\mathrm{Sm} / \mathrm{Nd}$ ratios and possibly higher

$798 \mathrm{Lu} / \mathrm{Hf}$ ratios will result in relatively less radiogenic $\mathrm{Nd}$ isotopes for a given $\mathrm{Hf}$ isotopes,

799 as frequently observed in oceanic peridotites (Bizimis et al., 2003; Bizimis et al., 2007; 
800 Stracke et al., 2011). Detailed experimental data on the mobility of REE out of

801 serpentinites during dehydration are critically needed to further test this hypothesis.

\section{$802 \quad 7.0$ Conclusions}

803 The combined in situ trace element determinations, and sequential leaching

804 experiments in serpentinized abyssal peridotites reveal that a seawater trace element

805 signature is primarily confined within the secondary minerals of serpentine and

806 magnetite. The Nd isotopic shifts between clinopyroxene, bulk rock and leachates,

807 together with the high LREE/HFSE ratios and negative Ce-anomalies are all consistent

808 with LREE addition to the peridotite during serpentinization, as opposed to exchange.

809 An accurate assessment of the water / rock mass ratios during serpentinization requires

810 knowledge of the primary (mantle) isotopic composition of the rock (usually through

811 clinopyroxene analysis) and the trace element systematics of the rock. Modification of

812 the LREE and LREE/HFSE ratios during serpentinization has implications for the trace

813 element budget and possibly $\mathrm{Nd}$ and $\mathrm{Hf}$ isotope systematics of recycled lithosphere and

814 as a function of the mobility of these elements during dehydration of the serpentinized

815 lithosphere within the subduction factory. Finally, based on the preferential addition of

816 LREE compared to HFSE, we can surmise that HFSE are potentially a better recorder of

817 primary magmatic processes in serpentinized peridotites.

\section{Acknowledgments}

819 Vincent Salters and Henry Dick are thanked for providing access to the SWIR

820 peridotites. The thorough and probing reviews of Ivan Savov and Fabien Deschamps and

821 the editorial handling by Marco Scambelluri are all gratefully acknowledged and

822 appreciated. We thank Dr. Dionysis Foustoukos for his comments and suggestions. This 
823 work was supported by the US National Science Foundation, through grants NSF-OCE

824 0928280, and NSF-EAR 1347890 to MB. Carl Frisby acknowledges support from a

825 SPARC Graduate Research Award from the University of South Carolina.

826

827

828

829

830

831

832

833

834

835

\section{References}

837 Allen, D.E., Seyfried, W.E., 2003. Compositional controls on vent fluids from ultramafic-

838 hosted hydrothermal systems at mid-ocean ridges: An experimental study at

840

841

842

843 Alibo, D.S., Nozaki, Y., 1999. Rare earth elements in seawater: particle association,

844

845 shale-normalization, and Ce oxidation. Geochimica et Cosmochimica Acta, 63(34): 363-372. 
846 Alt, J.C. et al., 2013. The role of serpentinites in cycling of carbon and sulfur: Seafloor

847 serpentinization and subduction metamorphism. Lithos, 178: 40-54.

848 Bach, W., Früh-Green, G.L., 2010. Alteration of the oceanic lithosphere and implications

849 for seafloor processes. Elements, 6(3): 173-178.

850 Beard, J.S. et al., 2009. Onset and progression of serpentinization and magnetite

851 formation in olivine-rich troctolite from IODP Hole U1309D. Journal of

$852 \quad$ Petrology, 50(3): 387-403.

853 Berndt, M.E., Seyfried, W.E., Beck, J.W., 1988. Hydrothermal alteration processes at

854 midocean ridges: Experimental and theoretical constraints from $\mathrm{Ca}$ and $\mathrm{Sr}$

855 exchange reactions and Sr isotopic ratios. Journal of Geophysical Research: Solid

$856 \quad$ Earth, 93(B5): 4573-4583.

857 Bizimis, M., Sen, G., Salters, V.J.M., 2004. Hf-Nd isotope decoupling in the oceanic

858 lithosphere: constraints from spinel peridotites from Oahu, Hawaii. Earth and

$859 \quad$ Planetary Science Letters, 217: 43-58.

860 Bizimis, M., M. Griselin, J. C. Lassiter, V. J. M. Salters and G. Sen, 2007. Ancient

861 recycled mantle lithosphere in the Hawaiian plume: Osmium-Hafnium isotopic

862 evidence from peridotite mantle xenoliths. Earth and Planetary Science Letters

$863 \quad 257: 259-273$.

864 Byrne, R.H., Kim, K.-H., 1990. Rare earth element scavenging in seawater. Geochimica

865 et Cosmochimica Acta, 54(10): 2645-2656.

866 Cannat, M. et al., 1995. Thin crust, ultramafic exposures, and rugged faulting patterns at 867 the Mid-Atlantic Ridge $\left(22^{\circ}-24^{\circ} \mathrm{N}\right)$. Geology, 23(1): 49-52. 
868 Cannat, M., Fontaine, F., Escartin, J., 2010. Serpentinization at slow-spreading ridges:

869 extent and associated hydrogen and methane fluxes, in diversity of hydrothermal 870 systems on slow spreading ocean ridge. In: Rona, P.A., Devey, C.W., Dyment, J.,

871 Murton, B.J. (Eds.), Diversity of hydrothermal systems on slow spreading ocean 872 ridges. American Geophysical Union, Washington, pp. 241-264.

873 Carlson, R.L., 2001. The abundance of ultramafic rocks in Atlantic Ocean crust. $874 \quad$ Geophysical Journal International, 144(1): 37-48.

875 Chen, J.H., Edwards, R.L., Wasserburg, G.J., 1986. ${ }^{238} \mathrm{U},{ }^{234} \mathrm{U}$ and ${ }^{232} \mathrm{Th}$ in seawater. 876 Earth Plan. Sci. Lett., 80: 241-251.

877 Chester, R., Hughes, M.J., 1967. A chemical technique for the separation of ferro878 manganese minerals, carbonate minerals and adsorbed trace elements from 879 pelagic sediments. Chemical Geology, 2(0): 249-262.

880 Cipriani, A., Brueckner, H.K., Bonatti, E., Brunelli, D., 2004. Oceanic crust generated by 881 elusive parents: $\mathrm{Sr}$ and $\mathrm{Nd}$ isotopes in basalt-peridotite pairs from the Mid$882 \quad$ Atlantic Ridge. Geology, 32: 657-660.

883 Coppin, F., Berger, G., Bauer, A., Castet, S., Loubet, M., 2002. Sorption of lanthanides 884 on smectite and kaolinite. Chemical Geology, 182(1): 57-68.

885 De Baar, H.J.W., Bacon, M.P., Brewer, P.G., Bruland, K.W., 1985a. Rare earth elements 886 in the Pacific and Atlantic Oceans. Geochimica et Cosmochimica Acta, 49(9): 1943-1959.

888 De Baar, H.J.W., Brewer, P.G., Bacon, M.P., 1985b. Anomalies in rare earth distributions 889 in seawater: Gd and Tb. Geochimica et Cosmochimica Acta, 49(9): 1961-1969. 
890 Delacour, A., Früh-Green, G.L., Frank, M., Gutjahr, M., Kelley, D.S., 2008. Sr- and Nd891 isotope geochemistry of the Atlantis Massif $\left(30^{\circ} \mathrm{N}, \mathrm{MAR}\right)$ : Implications for fluid 892 fluxes and lithospheric heterogeneity. Chemical Geology, 254(1-2): 19-35.

893 Deschamps, F. et al., 2010. In situ characterization of serpentinites from forearc mantle 894 wedges: Timing of serpentinization and behavior of fluid-mobile elements in 895 subduction zones. Chemical Geology, 269(3-4): 262-277.

896 Deschamps, F., Guillot, S., Godard, M., Andreani, M., Hattori, K., 2011. Serpentinites act as sponges for fluid-mobile elements in abyssal and subduction zone environments. Terra Nova, 23(3): 171-178.

Deschamps, F. et al., 2012. Behavior of fluid-mobile elements in serpentines from 900 abyssal to subduction environments: Examples from Cuba and Dominican 901 Republic. Chemical Geology, 312-313: 93-117.

902 Deschamps, F., Godard, M., Guillot, S., Hattori, K., 2013. Geochemistry of subduction 903 zone serpentinites: A review. Lithos, 178: 96-127.

904 Dick, H.J.B., Lin, J., Schouten, H., 2003. An ultraslow-spreading class of ocean ridge. $905 \quad$ Nature, 426(6965): 405-412.

906 Duncan, T., Shaw, T., 2003. The mobility of rare earth elements and redox sensitive 907 elements in the groundwater/seawater mixing zone of a shallow coastal aquifer. $908 \quad$ Aquatic Geochemistry, 9(3): 233-255.

909 Elderfield, H., Greaves, M. J., 1982. The rare earth elements in seawater. Nature, 296: $910 \quad 214-219$. 
911 Elderfield, H., Upstill-Goddard, R., Sholkovitz, E.R., 1990. The rare earth elements in

912 rivers, estuaries, and coastal seas and their significance to the composition of

913 ocean waters. Geochimica et Cosmochimica Acta, 54: 971-991.

914 Erel, Y., Morgan, J.J., 1991. The effect of surface reactions on the relative abundances of

915 trace metals in deep-ocean water. Geochimica et Cosmochimica Acta, 55(7):

$916 \quad 1807-1813$.

917 Foustoukos, D. I., \& Seyfried, W. E. (2007). Fluid phase separation processes in

918 submarine hydrothermal systems. Reviews in Mineralogy and Geochemistry,

$919 \quad$ 65(1): 213-239.

920 Foustoukos, D.I., Savov, I.P., Janecky, D.R., 2008. Chemical and isotopic constraints on

921 water/rock interactions at the Lost City hydrothermal field, $30^{\circ} \mathrm{N}$ Mid-Atlantic

922 Ridge. Geochimica et Cosmochimica Acta, 72(22): 5457-5474.

923 Frisby, C.P., Bizimis, M., Foustoukos, D.I., 2011. Experimental evidence for Nd-Sr

924 decoupling during low-temperature $\left(20-170^{\circ} \mathrm{C}\right)$ hydrothermal alteration of olivine

925 and clinopyroxene. Abstract V41C-2507 presented at 2011 Fall Meeting,

926 AGU,San Francisco, Calif., 5-9 Dec.

927 Frisby, C.P., Bizimis, M., Foustoukos, D., 2013. The effect of temperature and surface

928 area on $\mathrm{Sr}, \mathrm{Ba}$ and $\mathrm{REE}$ fractionation during low temperature serpentinization,

929 Abstract OS41C-1837 presented at 2011 Fall Meeting, AGU,San Francisco,

930 Calif., 9-13 Dec.

931 Frost, B.R., Beard, J.S., 2007. On silica activity and serpentinization. Journal of

932 Petrology, 48(7): 1351-1368. 
933 Frost, B.R., Evans, K.A., Swapp, S.M., Beard, J.S., Mothersole, F.E., 2013. The process

934 of serpentinization in dunite from New Caledonia. Lithos, 178: 24-39.

935 Harvey, J., Savov, I.P., Agostini, S., Cliff, R.A., Walshaw, R., 2014. Si-metasomatism in

936 serpentinized peridotite: The effects of talc-alteration on strontium and boron

937 isotopes in abyssal serpentinites from Hole 1268a, ODP Leg 209. Geochimica et

$938 \quad$ Cosmochimica Acta, 126: 30-48.

939 Hauri, E., Wagner, T.P., Grove, T.L., 1994. Experimental and natural partitioning of Th,

$940 \mathrm{U}, \mathrm{Pb}$ and other trace elements between garnet, clinopyroxene and basaltic melts.

$941 \quad$ Chemical Geology, 117: 149-166.

942 Humayun, M., Davis, F.A., Hirschmann, M.M., 2010. Major element analysis of natural

943 silicates by laser ablation ICP-MS. Journal of Analytical Atomic Spectrometry, 944 25(7): 998-1005.

945 Jöns, N., Bach, W., Klein, F., 2010. Magmatic influence on reaction paths and element 946 transport during serpentinization. Chemical Geology, 274(3-4): 196-211.

947 Kelemen, P.B., Yogodzinski, G.M., Scholl, D.W., 2004. Along-Strike variation in the

$948 \quad$ Aleutian Island Arc: Genesis of high Mg\# andesite and implications for

949 continental crust, inside the subduction factory. American Geophysical Union, pp.

$950 \quad 223-276$.

951 Kessel, R., Schmidt, M.W., Ulmer, P., Pettke, T., 2005. Trace element signature of

952 subduction-zone fluids, melts and supercritical liquids at 120-180km depth.

$953 \quad$ Nature, 437(7059): 724-727. 
954 Kessel, R., Fumagalli, P., Pettke, T., 2015. The behaviour of incompatible elements 955 during hydrous melting of metasomatized peridotite at $4-6 \mathrm{GPa}$ and $1000{ }^{\circ} \mathrm{C}-$ $956 \quad 1200{ }^{\circ} \mathrm{C}$. Lithos, 236-237: 141-155.

957 Kodolányi, J., Pettke, T., Spandler, C., Kamber, B.S., Gméling, K., 2012. Geochemistry 958 of ocean floor and fore-arc serpentinites: Constraints on the ultramafic input to 959 subduction zones. Journal of Petrology, 53(2): 235-270.

960 Lafay, R. et al., 2013. High-pressure serpentinites, a trap-and-release system controlled by metamorphic conditions: Example from the Piedmont zone of the western

963 Lapen, T., Medaris, L.G., Jr., Johnson, C., Beard, B., 2005. Archean to Middle

964 Proterozoic evolution of Baltica subcontinental lithosphere: evidence from 965 combined $\mathrm{Sm}-\mathrm{Nd}$ and $\mathrm{Lu}-\mathrm{Hf}$ isotope analyses of the Sandvik ultramafic body, 966 Norway. Contributions to Mineralogy and Petrology, 150(2): 131-145.

967 Mallick, S., Dick, H.J.B., Sachi-Kocher, A., Salters, V.J.M., 2014. Isotope and trace 968 element insights into heterogeneity of subridge mantle. Geochemistry, 969 Geophysics, Geosystems, 15(6): 2438-2453.

970 Mallick, S., Standish, J.J., Bizimis, M., 2015. Constraints on the mantle mineralogy of an 971 ultra-slow ridge: Hafnium isotopes in abyssal peridotites and basalts from the 9$97225^{\circ} \mathrm{E}$ Southwest Indian Ridge. Earth and Planetary Science Letters, 410(0): 42-53.

973 Mazza, S. E., E. Gazel, E. A. Johnson, M. J. Kunk, R. McAleer, J. A. Spotila, M.

974 Bizimis, and D. S. Coleman (2014), Volcanoes of the passive margin: The 975 youngest magmatic event in eastern North America, Geology, 42(6), 483-486, $976 \quad 10.1130 / \mathrm{g} 35407.1$ 
977 McCulloch, M.T., Gregory, R.T., Wasserburg, G.J., Taylor, H.P.J., 1980. A neodymium,

978 strontium, and oxygen isotopic study of the Cretaceous Samail ophiolite and

979 implications for the petrogenesis and seawater-hydrothermal alteration of oceanic

$980 \quad$ crust. Earth Plan Sci Lett, 46: 201-211.

981 McDade, P., Blundy, J.D., Wood, B.J., 2003. Trace element partitioning on the

982 Tinaquillo lherzolite solidus at 1.5 GPa. Physics of the Earth and Planet Interiors, 983 139(1-2): 129-147.

984 Menzies, M.A., Long, A., Ingram, G., Tatnell, M., Janecky, D., 1993. MORB peridotite-

985 sea water interaction: experimental constraints on the behaviour of trace elements,

986

${ }^{87} \mathrm{Sr} /{ }^{86} \mathrm{Sr}$ and ${ }^{143} \mathrm{Nd} /{ }^{144} \mathrm{Nd}$ ratios. Geological Society, London, Special

987 Publications, 76(1): 309-322.

988 Mével, C., 2003. Serpentinization of abyssal peridotites at mid-ocean ridges. Comptes

989 Rendus Geoscience, 335(10-11): 825-852.

990 Niu, Y., 2004. Bulk-rock Major and Trace Element Compositions of Abyssal Peridotites:

991 Implications for Mantle Melting, Melt Extraction and Post-melting Processes

992 Beneath Mid-Ocean Ridges. Journal of Petrology, 45(12): 2423-2458.

993 O'Nions, R.K., Hamilton, P.J., Evensen, N.M., 1977. Variations in ${ }^{143} \mathrm{Nd} /{ }^{144} \mathrm{Nd}$ and

$994 \quad{ }^{87} \mathrm{Sr} /{ }^{86} \mathrm{Sr}$ ratios in oceanic basalts. Earth Planet. Sci. Lett., 34: 13-22.

995 Paulick, H. et al., 2006. Geochemistry of abyssal peridotites (Mid-Atlantic Ridge, $15^{\circ} 20$

996 N, ODP Leg 209): Implications for fluid/rock interaction in slow spreading

997 environments. Chemical Geology, 234(3-4): 179-210.

998 Piepgras, D.J., Wasserburg, G.J., Dasch, E.J., 1979. The isotopic compositions of

999 neodymiun in different ocean masses. Earth Plan Sci Lett, 45: 223-236. 
1000 Piepgras, D. J., Jacobsen, S. B., 1992. The behavior of rare earth elements in seawater:

1001 Precise determinations of variations in the North Pacific water column.

1002 Geochimica et Cosmochimica Acta, 56: 1 851-1 862.

1003 Quinn, K.A., Byrne, R.H., Schijf, J., 2006a. Sorption of yttrium and rare earth elements

1004 by amorphous ferric hydroxide: Influence of $\mathrm{pH}$ and ionic strength. Marine

1005 Chemistry, 99(1-4): 128-150.

1006 Quinn, K.A., Byrne, R.H., Schijf, J., 2006b. Sorption of yttrium and rare earth elements

1007 by amorphous ferric hydroxide: Influence of solution complexation with

1008 carbonate. Geochimica et Cosmochimica Acta, 70(16): 4151-4165.

1009 Quinn, K.A., Byrne, R.H., Schijf, J., 2007. Sorption of yttrium and rare earth elements by

$1010 \quad$ amorphous ferric hydroxide: Influence of temperature. Environmental Science \&

$1011 \quad$ Technology, 41(2): 541-546.

1012 Salters, V.J.M., Dick, H.J.B., 2002. Mineralogy of the mid-ocean-ridge basalt source

1013 from neodymium isotopic composition of abyssal peridotites. Nature, 418: 68-72.

1014 Salters, V.J.M., Longhi, J.E., Bizimis, M., 2002. Near mantle solidus trace element

1015 partitioning at pressures up to $3.4 \mathrm{GPa}$. Geochemistry Geophysics Geosystems,

$1016 \quad 3(7): 1525-2027$.

1017 Salters, V.J.M., Stracke, A., 2004. Composition of the depleted mantle. Geochemistry, 1018 Geophysics, Geosystems, 5(5): 1525-2027.

1019 Savov, I. P., J. G. Ryan, M. D'Antonio, and P. Fryer, 2007. Shallow slab fluid release

1020 across and along the Mariana arc-basin system: Insights from geochemistry of

1021 serpentinized peridotites from the Mariana fore arc. Journal of Geophysical

$1022 \quad$ Research, 112, B09205. 
1023 Scambelluri, M., Fiebig, J., Malaspina, N., Müntener, O., Pettke, T., 2004. Serpentinite

1024 subduction: Implications for fluid processes and trace-element recycling.

1025 International Geology Review, 46(7): 595-613.

1026 Schijf, J., Marshall, K.S., 2011. YREE sorption on hydrous ferric oxide in $0.5 \mathrm{M} \mathrm{NaCl}$

1027 solutions: A model extension. Marine Chemistry, 123(1-4): 32-43.

1028 Sholkovitz, E.R., Landing, W.M., Lewis, B.L., 1994. Ocean particle chemistry: The

1029 fractionation of rare earth elements between suspended particles and seawater.

$1030 \quad$ Geochimica et Cosmochimica Acta, 58(6): 1567-1579.

1031 Snow, J.E., Hart, S.R., Dick, H.J.B., 1993. Orphan Strontium-87 in abyssal peridotites:

1032 Daddy was a granite. Science, 262: 1861-1863.

1033 Snow, J.E., Hart, S.R., Dick, H.J.B., 1994. Nd and Sr isotope evidence linking mid-ocean 1034 ridge basalts and abyssal peridotites. Nature, 371: 57-60.

1035 Snow, J.E., Reisberg, L., 1995. Os isotopic systematics of altered abyssal peridotites.

$1036 \quad$ Earth and Planetary Science Letters, 135: 411-421.

1037 Snyder, G.T., Savov, I. P., Muramatsu, Y., 2004. Iodine and boron in Mariana serpentine

1038 mud volcanoes (ODP 125 and 195): Implications for forearc processes and

1039 subduction recycling, In Shinohara, M., Salisbury, M.H., and Richter, C. (Eds.),

$1040 \quad$ Proc. ODP, Sci. Results, 195.

1041 Sonke, J.E., Salters, V.J.M., 2006. Lanthanide-humic substances complexation. I.

1042 Experimental evidence for a lanthanide contraction effect. Geochimica et

1043 Cosmochimica Acta, 70(6): 1495-1506. 
1044 Spandler, C., Pettke, T., Hermann, J., 2014. Experimental study of trace element release 1045 during ultrahigh-pressure serpentinite dehydration. Earth and Planetary Science $1046 \quad$ Letters, 391: 296-306.

1047 Standish, J.J., Dick, H.J.B., Michael, P.J., Melson, W.G., O'Hearn, T., 2008. MORB 1048 generation beneath the ultraslow spreading Southwest Indian Ridge (9-25 ${ }^{\circ}$ ):

1049 Major element chemistry and the importance of process versus source. $1050 \quad$ Geochemistry Geophysics Geosystems, 9(5): Q05004.

1051 Stichel, T., Frank, M., Rickli, J., Haley, B.A., 2012. The hafnium and neodymium isotope 1052 composition of seawater in the Atlantic sector of the Southern Ocean. Earth and 1053 Planetary Science Letters, 317-318: 282-294.

1054 Stracke, A. et al., 2011. Abyssal peridotite Hf isotopes identify extreme mantle depletion. 1055 Earth and Planetary Science Letters, 308(3-4): 359-368.

1056 Stern, J.C., Foustoukos, D.I., Sonke, J.E., Salters, V.J.M., 2014. Humic acid 1057 complexation of $\mathrm{Th}, \mathrm{Hf}$ and $\mathrm{Zr}$ in ligand competition experiments: Metal loading 1058 and pH effects. Chemical Geology, 363(0): 241-249.

1059 Stern, J.C., Sonke, J.E., Salters, V.J.M., 2007. A capillary electrophoresis-ICP-MS study 1060 of rare earth element complexation by humic acids. Chemical Geology, 246(3-4): $1061 \quad 170-180$.

1062 Sun, C., Liang, Y., 2014. An assessment of subsolidus re-equilibration on REE 1063 distribution among mantle minerals olivine, orthopyroxene, clinopyroxene, and 1064 garnet in peridotites. Chemical Geology, 372: 80-91. 
1065 Tang, J., Johannesson, K.H., 2005. Adsorption of rare earth elements onto Carrizo sand:

1066 Experimental investigations and modeling with surface complexation.

1067 Geochimica et Cosmochimica Acta, 69(22): 5247-5261.

1068 Tatsumi, Y., Hamilton, D.L., Nesbitt, R.W., 1986. Chemical characteristics of fluid phase

1069 released from a subducted lithosphere and origin of arc magmas: Evidence from

1070 high-pressure experiments and natural rocks. Journal of Volcanology and

1071 Geothermal Research, 29(1-4): 293-309.

1072 Warren, J.M., Shimizu, N., Sakaguchi, C., Dick, H.J.B., Nakamura, E., 2009. An

1073 assessment of upper mantle heterogeneity based on abyssal peridotite isotopic

1074 compositions. Journal of Geophysical Research, 114(B12203).

1075 Weis, D., Kieffer, B., Maerschalk, C., Pretorius, W., Barling, J., 2005. High-precision Pb-

1076 Sr-Nd-Hf isotopic characterization of USGS BHVO-1 and BHVO-2 reference

1077 materials. Geochemistry Geophysics Geosystems, 6(2): Q02002.

1078 Whalen, L., E. Gazel, C. Vidito, J. Puffer, M. Bizimis, W. Henika, and M. J. Caddick

1079 (2015), Supercontinental inheritance and its influence on supercontinental

1080 breakup: The central Atlantic magmatic province and the break up of Pangea,

1081 Geochemistry, Geophysics, Geosystems, 16, 3532-3554, 10.1002/2015GC005885

1082 Wood, B.J., Blundy, J.D., 1997. A predictive model for rare earth element partitioning 1083

1084 between clinopyroxene and anhydrous silicate melt. Contributions to Mineralogy

1085 Workman, R.K., Hart, S.R., 2005. Major and trace element composition of the depleted

1086 MORB mantle (DMM). Earth and Planetary Science Letters, 231: 53-72. 


\section{Figure Captions}

1090 Figure 1: Typical and common morphological features in the analyzed samples observed

1091 by SEM: A) Magnetite veins (bright features) in VAN 7-78-41 with feathery structures

1092 within serpentine. Note the predominance of magnetite at the center of the veined

1093 serpentine. Qualitative SEM data shows decreasing Fe content near the magnetite vein, as

1094 described by Beard et al. (2009). B) Olivine replacement by serpentine in VAN 7-78-39

1095 with vein and pseudomorphic texture. Different contrast areas are all variably altered

1096 olivine with often but not always slightly different $\mathrm{Fe} / \mathrm{Mg}$ ratios. Note magnetite is never

1097 found in contact with preserved olivine. D) Replacement of opx exsolution lamellae in

1098 cpx by serpentine (VAN 7-85-42). Note cross-cutting fractures through the lamellae are

1099 also serpentinized. Opx is preserved in the exsolutions at the bottom right of the figure.

1100 E) Flow structure preserved in serpentine with cross-cutting serpentine vein with

1101 preserved cpx and opx relics. Note the jagged edges of orthopyroxene on the right (VAN

1102 7-85-47). F) Detail of serpentine after olivine structure (VAN 7-85-47). Note the

1103 symmetric shading along the center of the veins where darker shades have lower Fe

1104 contents.

1105

1106 Figure 2: A) Primitive mantle normalized Rare Earth Element patterns, and B) extended

1107 trace element patterns of the bulk rock peridotites, determined by dissolution chemistry.

1108 VAN 7-78 samples are shown in dashed lines and VAN 7-85 samples in solid lines.

1109 Grey lines are serpentinized abyssal peridotites from Niu (2004), and Deschamps et al

1110 (2013).

1111 
1112 Figure 3: REE patterns for cpx (blue), opx (orange), all serpentine (grey), modeled

1113 primary OPX (orange dashed) and modeled primary olivine (green dashed) (see text for

1114 details). LREE enrichment is noted in the fresh cpx for samples VAN 7-78-36H and

1115 VAN 7-78-41. A negative Ce anomaly is observed in the serpentine of sample VAN 7-

$1116 \quad 78-39$ and all VAN 7-85 samples.

1117

1118 Figure 4: Extended trace element patterns for cpx (Blue), opx (orange), serpentine

1119 (grey), modeled primary opx (orange dashed) and modeled primary olivine (green

1120 dashed). General flatter pattern is noted in primary CPX for VAN 7-78-36H and VAN

1121 7-78-41. Serpentine phases have strong positive U, $\mathrm{Pb}$ and $\mathrm{Sr}$ anomalies, higher

1122 LREE/HREE, and often Ti depletions compared to modeled concentration patterns.

1124 Figure 5: Primitive mantle-normalized plagioclase and magnetite concentration patterns.

1125 A) Plagioclase REE, B) Plagioclase extended trace element patterns, C) magnetite REE

1126 and, D) magnetite extended trace element patterns.

1127

1128 Figure 6: Bulk rock REE reconstructed concentrations (dotted lines) from laser ablation

1129 data compared to bulk rock patterns determined via traditional dissolution chemistry.

1130 Samples VAN 7-78 (dashed lines) fits well for HREE, but the reconstructed REE are

1131 typically lower than measured. Samples Van 7-85 (solid lines) measured and modeled

1132 patterns fit well. For further description see text.

1133 
1134 Figure 7: Primitive mantle-normalized bulk rock extended trace element reconstructed

1135 concentration patterns (dotted lines) from laser ablation data compared to bulk rock

1136 patterns determined via traditional dissolution chemistry. Sample VAN 7-78-39 has a

1137 poorer fit to measured concentrations than VAN 7-78-36H and VAN 7-78-41 and the

1138 VAN 7-85 samples (solid lines), for which the patterns match well. For further discussion

1139 see text.

1140

1141 Figure 8: Primitive mantle-normalized REE patterns for bulk rock (black line), $\mathrm{H}_{2} \mathrm{O}$ -

1142 leachate (red line), NaOAc-leachate (green line), HH-leachate (purple line), 6N HCL-

1143 leachate (blues line), residual (leached) rock (orange line) and average seawater (grey

1144 dash-dot line; bottom right panel). Leachates mostly follow bulk rock patterns, but in the

1145 VAN 7-85 samples the NaOAc and HH leachates have flatter REE pattern than the bulk

1146 rock (see text for further discussion).

1147

1148 Figure 9: Primitive mantle-normalized extended trace element patterns for bulk rock,

1149 leachates and residual rock shown in figure 10. Note the characteristic depletions in Hf,

$1150 \mathrm{Zr}$, Ti relative to the REE in the NaOAc and $\mathrm{HH}$ leachates, implying excess REE addition

1151 during alteration. Also note the decrease in the Sr enrichment with progressive leaching

1152 (see text for further discussion).

1153

1154 Figure 10: Comparison of extended trace element patterns between measured (dashed

1155 lines) and reconstructed bulk rock using the leachate data (dotted line). 
1157 Figure 11: ${ }^{87} \mathrm{Sr} /{ }^{86} \mathrm{Sr}$ and $\varepsilon \mathrm{Nd}$ values for primary cpx (blue dot), bulk rock (orange

1158 triangle), leached rock (green square), $\mathrm{NaOAc}+\mathrm{HH}$ leachate (red square), and $6 \mathrm{~N} \mathrm{HCl}$

1159 leachate (red diamond) for each of the peridotites analyzed. Samples are compared to the

1160 MORB-OIB field and a rock-seawater interaction model using the equations given in

1161 Delacour et al. (2008). The model assumes isotopic equilibrium between seawater and

1162 bulk rock and no change in their respective concentrations (i.e., pure element and isotope

1163 exchange). Here we use the $\mathrm{Nd}$-isotope compositions of cpx for these peridotites

1164 reported in Mallick et al. (2014) and the measured bulk rock Nd concentration as the rock

1165 end-member. This assumes no change in the $\mathrm{Nd}$ concentrations of the peridotites during

1166 exchange. The Nd concentration and isotopic composition for seawater near the

1167 Southwest Indian Ridge is taken from Stichel et al., 2012 (SW). Tick marks along the

1168 lines show water/ rock mass ratios. The primary cpx falls within the MORB-OIB field

1169 while bulk rock falls closer to seawater, having more radiogenic $\mathrm{Sr}$ and less radiogenic

$1170 \mathrm{Nd}$ than the cpx. The leached peridotites plot closer to their respective cpx. The

1171 combined $\mathrm{NaOAc}+\mathrm{HH}$ leachates plot closer to seawater, while the $6 \mathrm{~N} \mathrm{HCl}$ leachate plots

1172 close to bulk rock for VAN 7-78 samples, and between bulk and leached rock for VAN

$1173 \quad 7-85$ samples.

1174

1175 Figure 12: Peridotite protolith REE reconstructed composition (blue lines) using

1176 determined modal abundances from bulk rock reconstruction models, where serpentine $=$

1177 olivine (see table 2), and cpx partition coefficients compared to measured bulk rock. For 1178 details see text. 
1180 Figure 13: $\mathrm{Ce} / \mathrm{Ce} *(\mathrm{Ce}$ anomaly) vs. U/Th where all ratios are determined from

1181 concentrations and $\mathrm{Ce} / \mathrm{Ce}^{*}$ is calculated as $\left.\mathrm{Ce} /(\mathrm{La}+\mathrm{Pr}) / 2\right)$. Where with increasing $\mathrm{U} / \mathrm{Th}$

1182 there is an increase in seawater influence due to the addition of $U$ and subsequently a

1183 decreasing $\mathrm{Ce} / \mathrm{Ce} *$ due to the addition of $\mathrm{Pr}$ and $\mathrm{La}$ to the peridotite.

1184

1185 Figure 14: Bulk Rock and leachate Ti vs. Nd (A) and $\mathrm{Hf}$ vs. Ti (B) where $\mathrm{Hf}$ for a given

1186 Ti has a tighter correlation in the bulk rock. NaOAc+HH leachates for a given Ti falls

1187 closer to the linear trend observed for $\mathrm{Hf}$ than that of $\mathrm{Nd}$, which has a higher overall

1188 concentration.

1189 


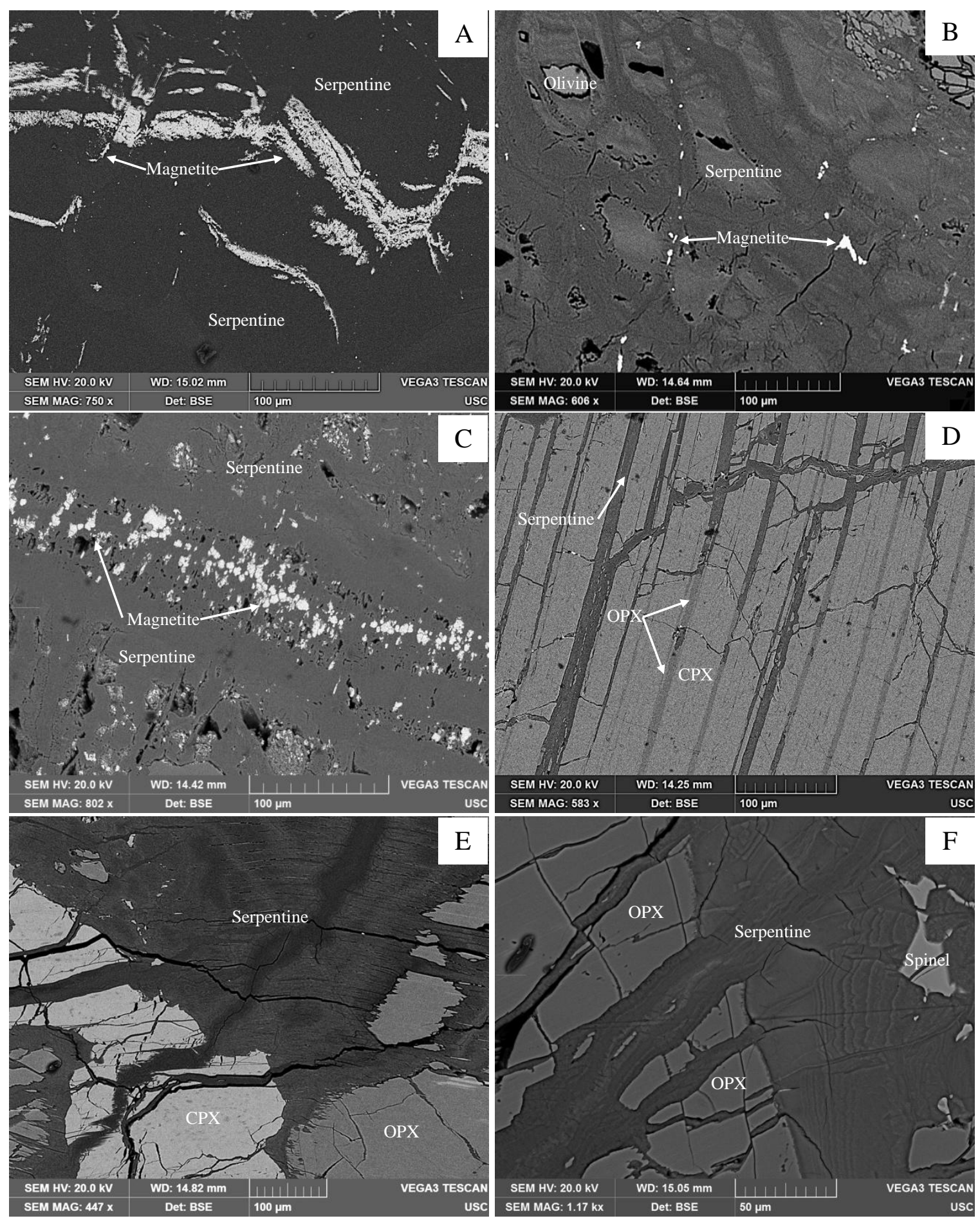




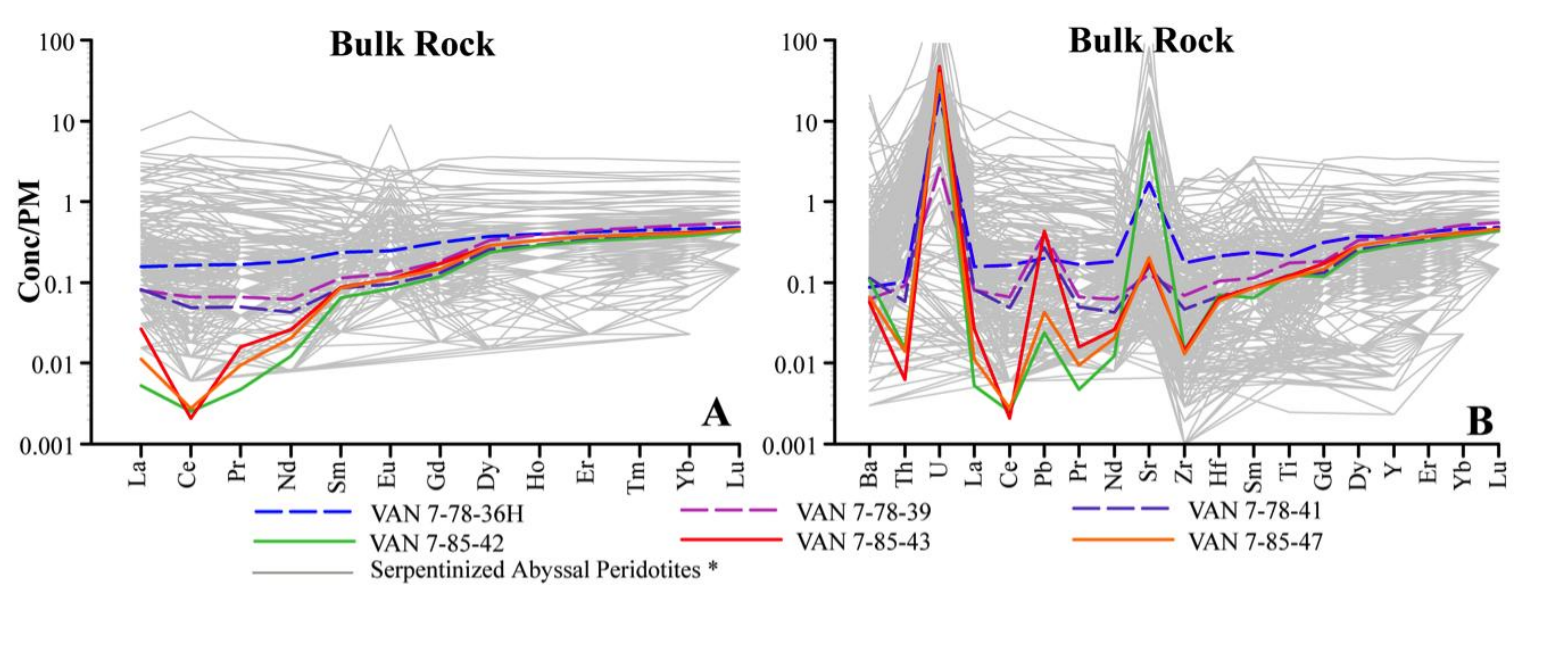

Figure 2

B

\section{Figure 2}

-

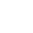

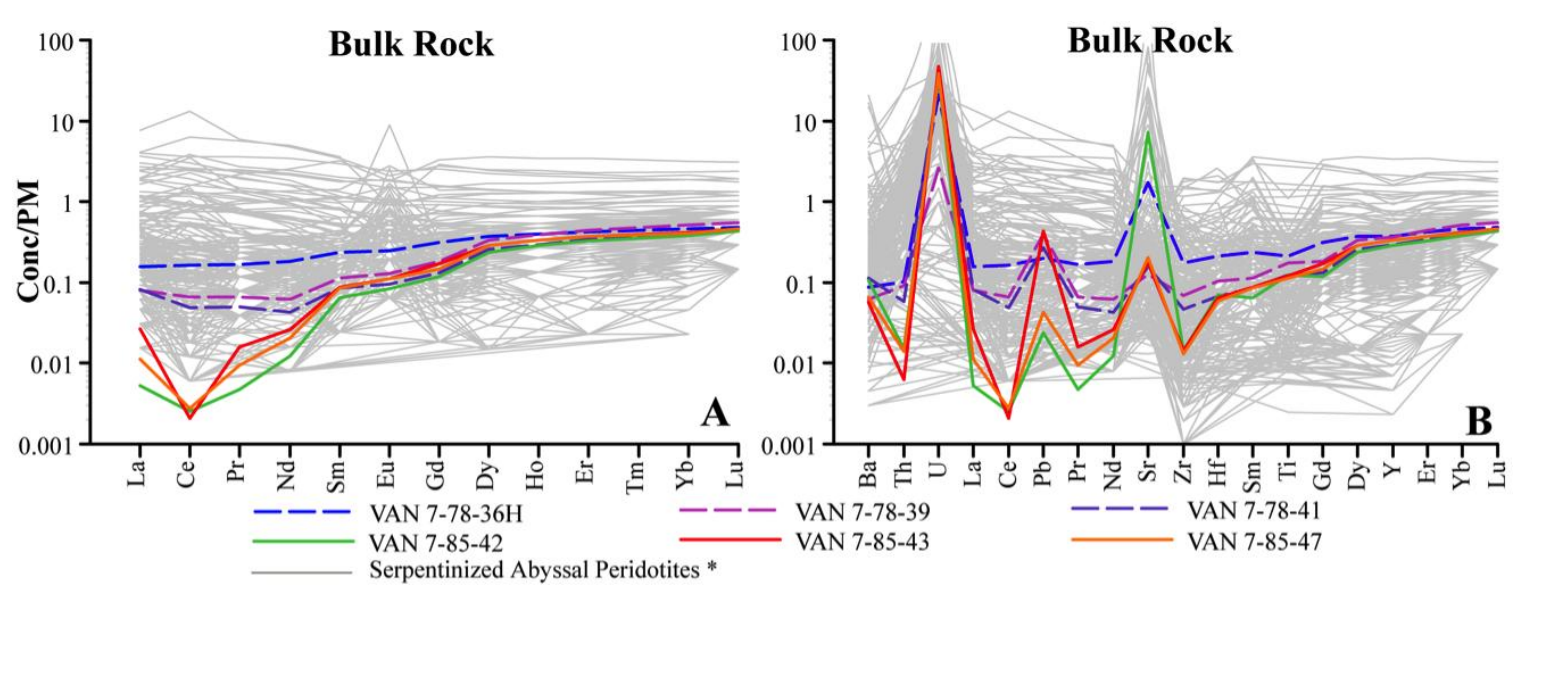

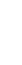

.

(n)

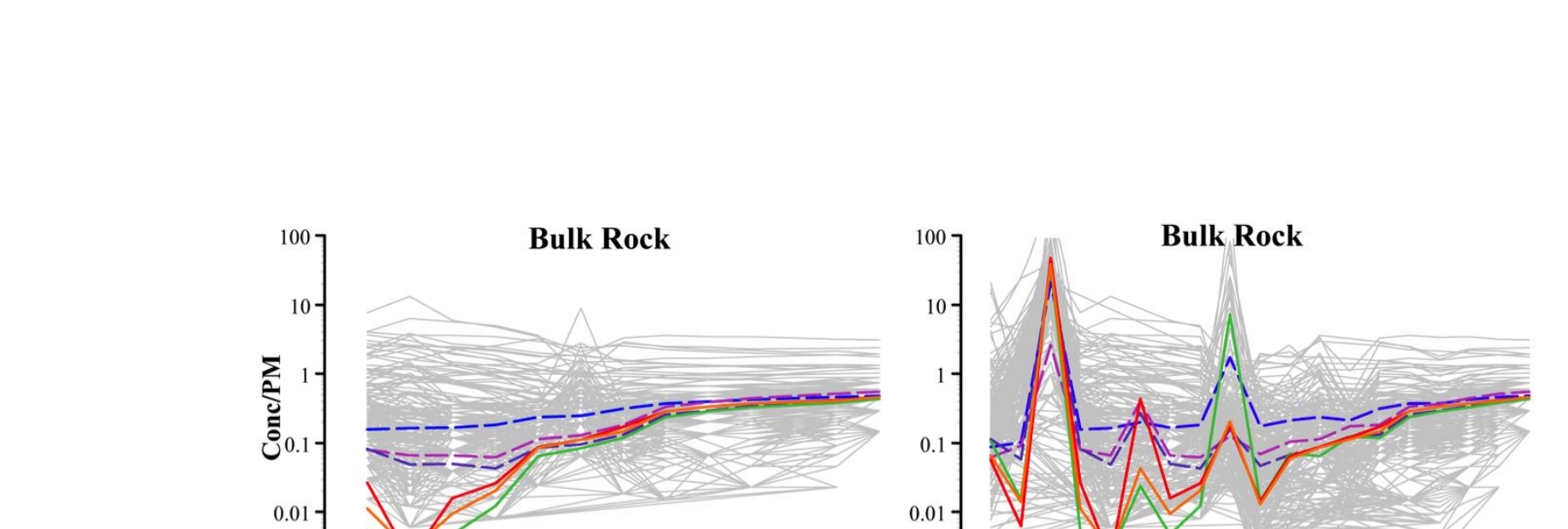

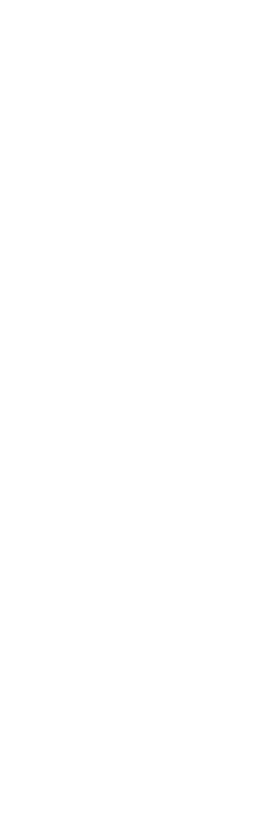

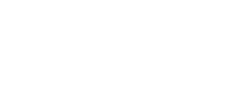

(

.

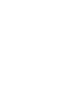$$
\text { . }
$$$$
\text { . }
$$$$
\text { . }
$$ 
Figure 3
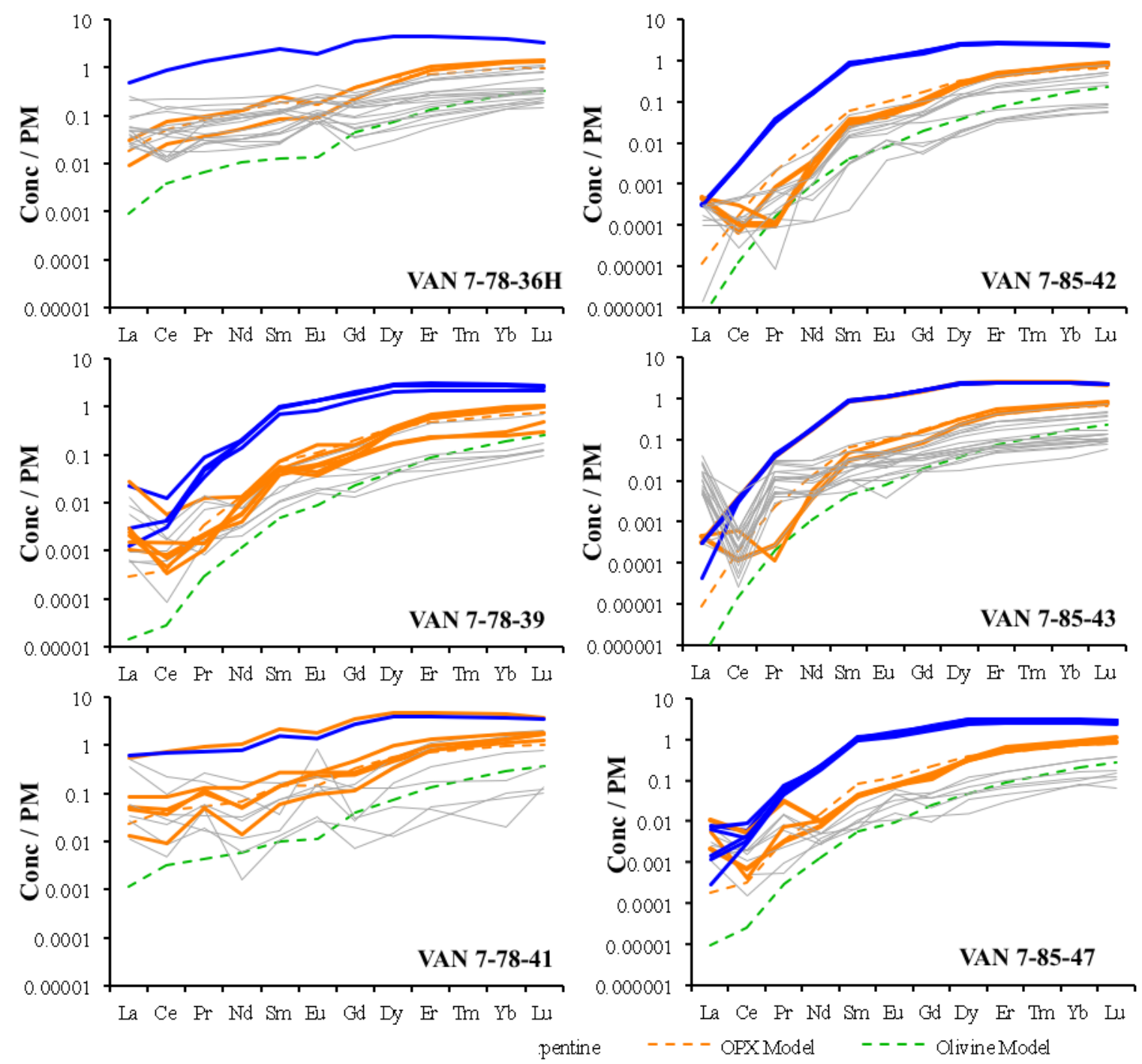

pentine

- - - OPXModel - - - - OlivineModel 

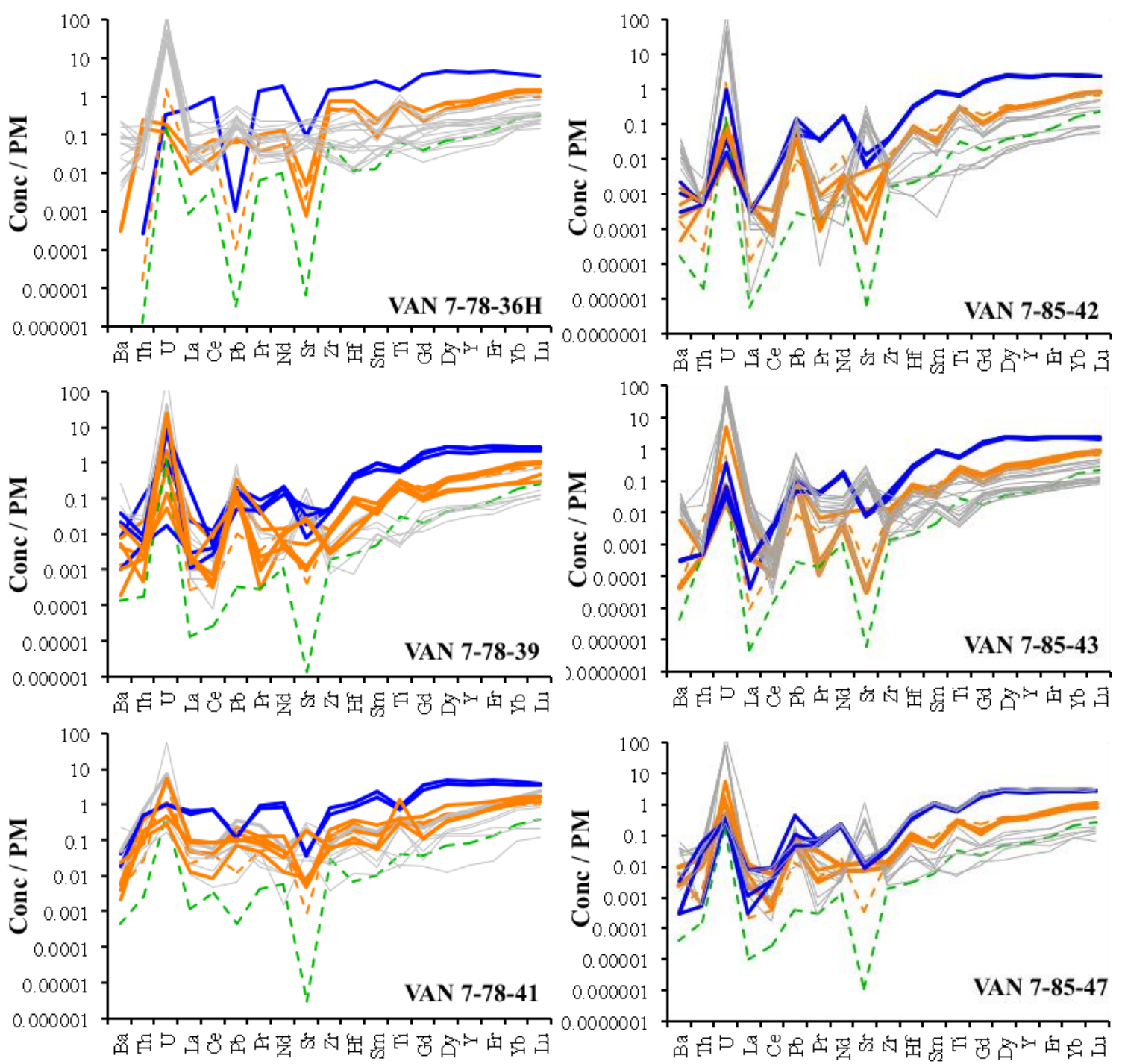

pentine 

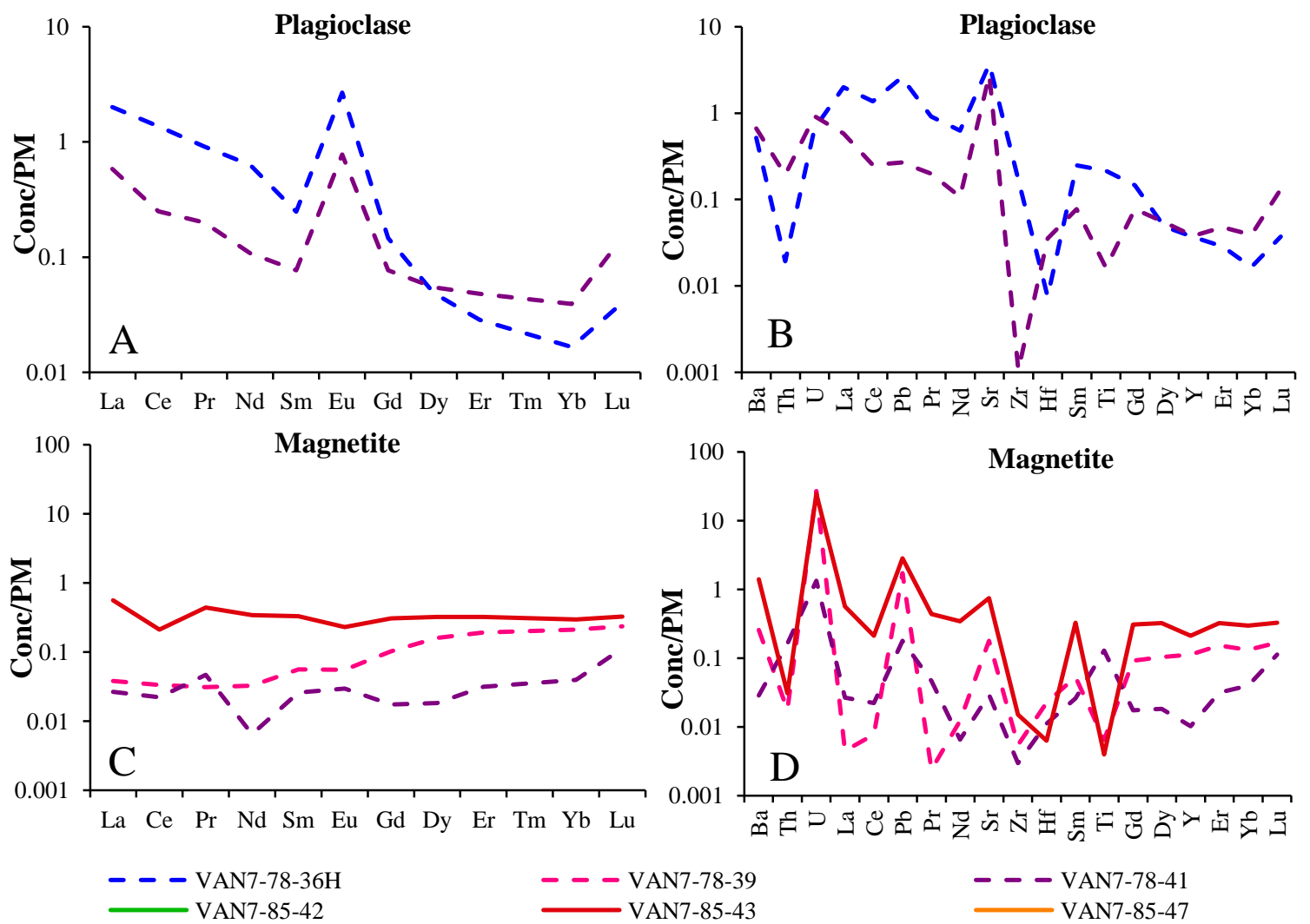

- - - VAN7-78-41 

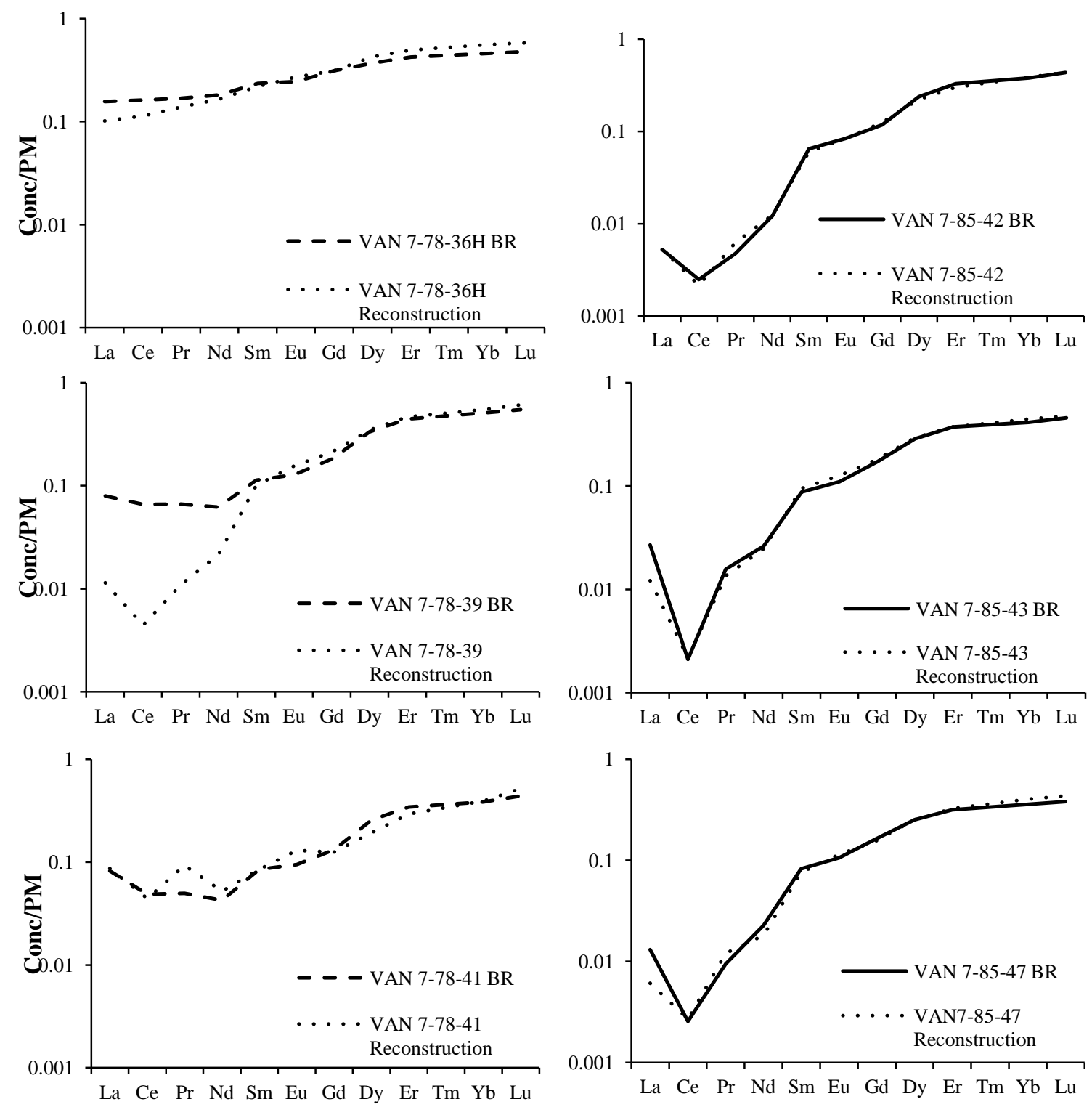

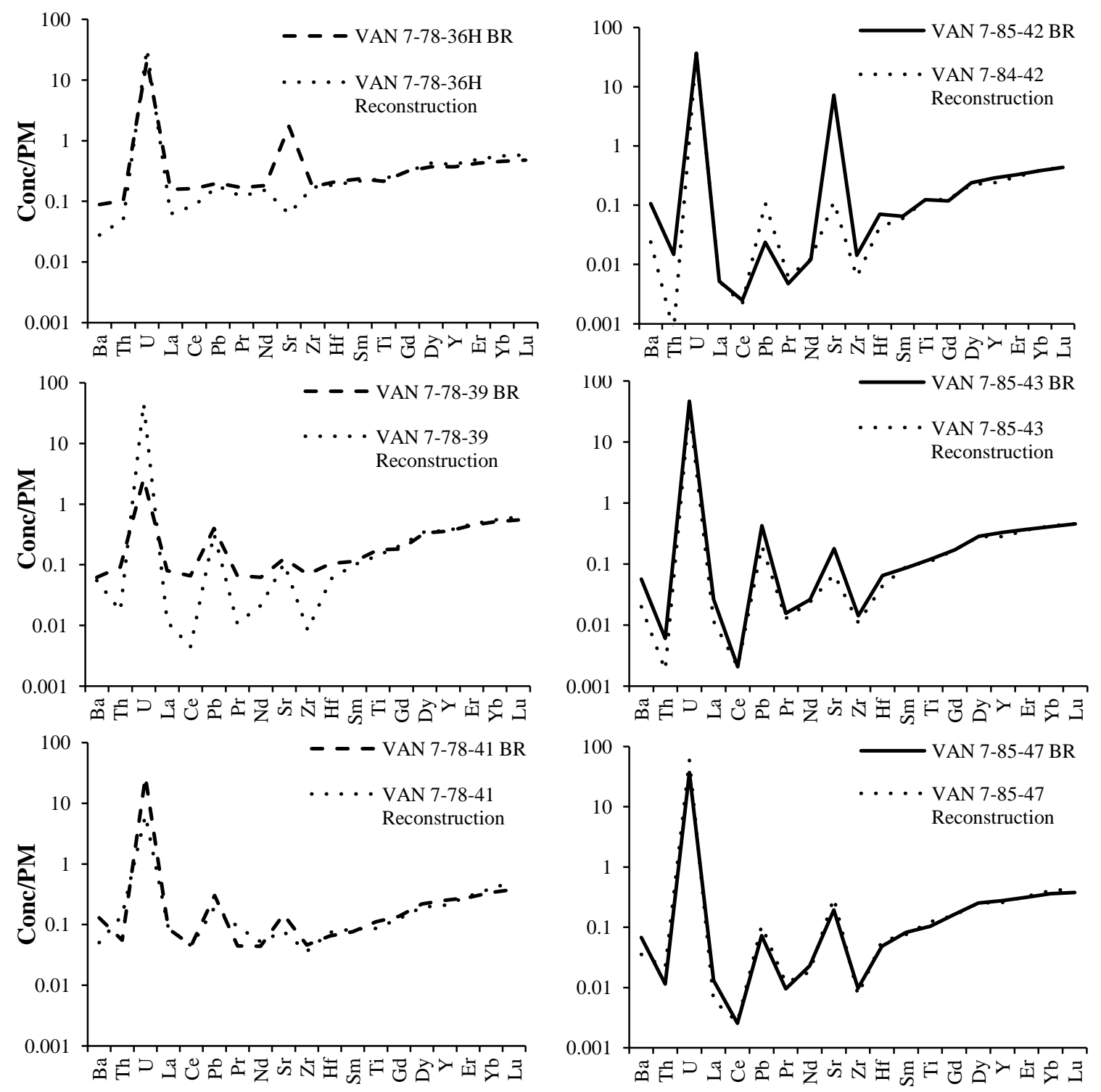

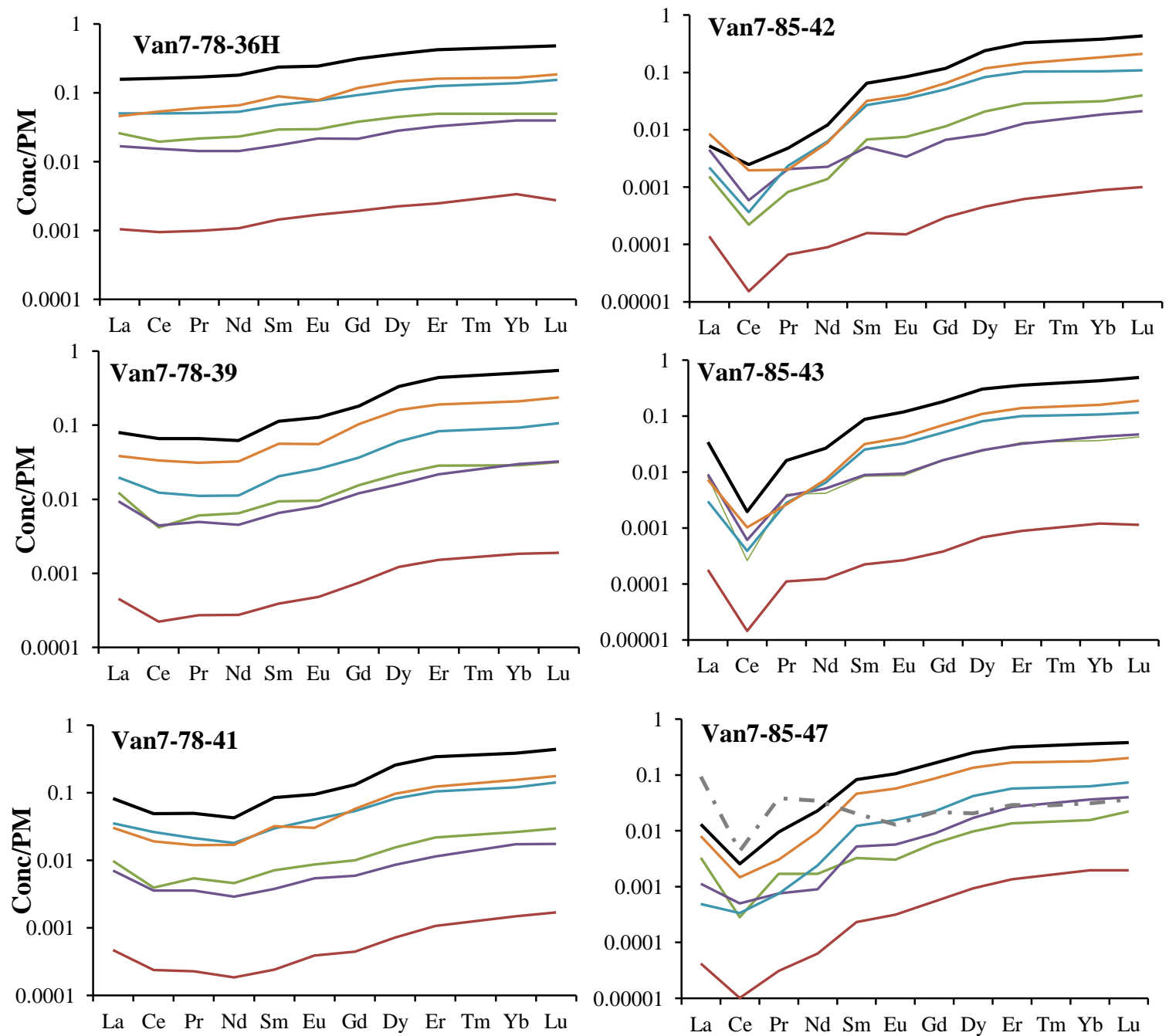

Pr Nd Sm Eu Gd Dy Er Tm Yb

$\mathrm{La} \mathrm{Ce}$ Pr $\mathrm{Nd} \mathrm{Sm}$ Eu Gd Dy Er Tm Yb Lu

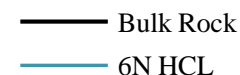

$\mathrm{H} 2 \mathrm{O}$ Leach

- Na Acetate

HH Leach 

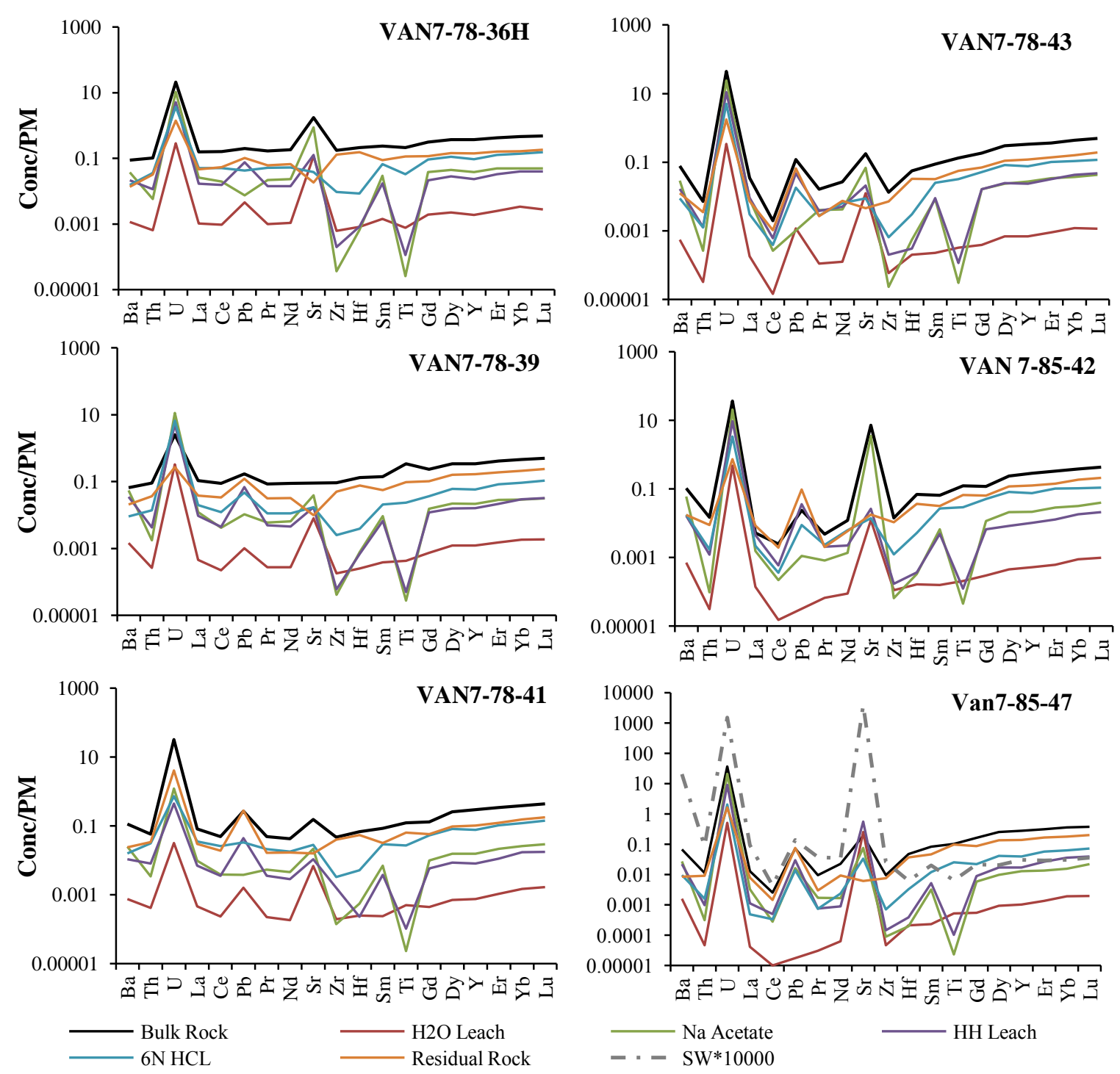


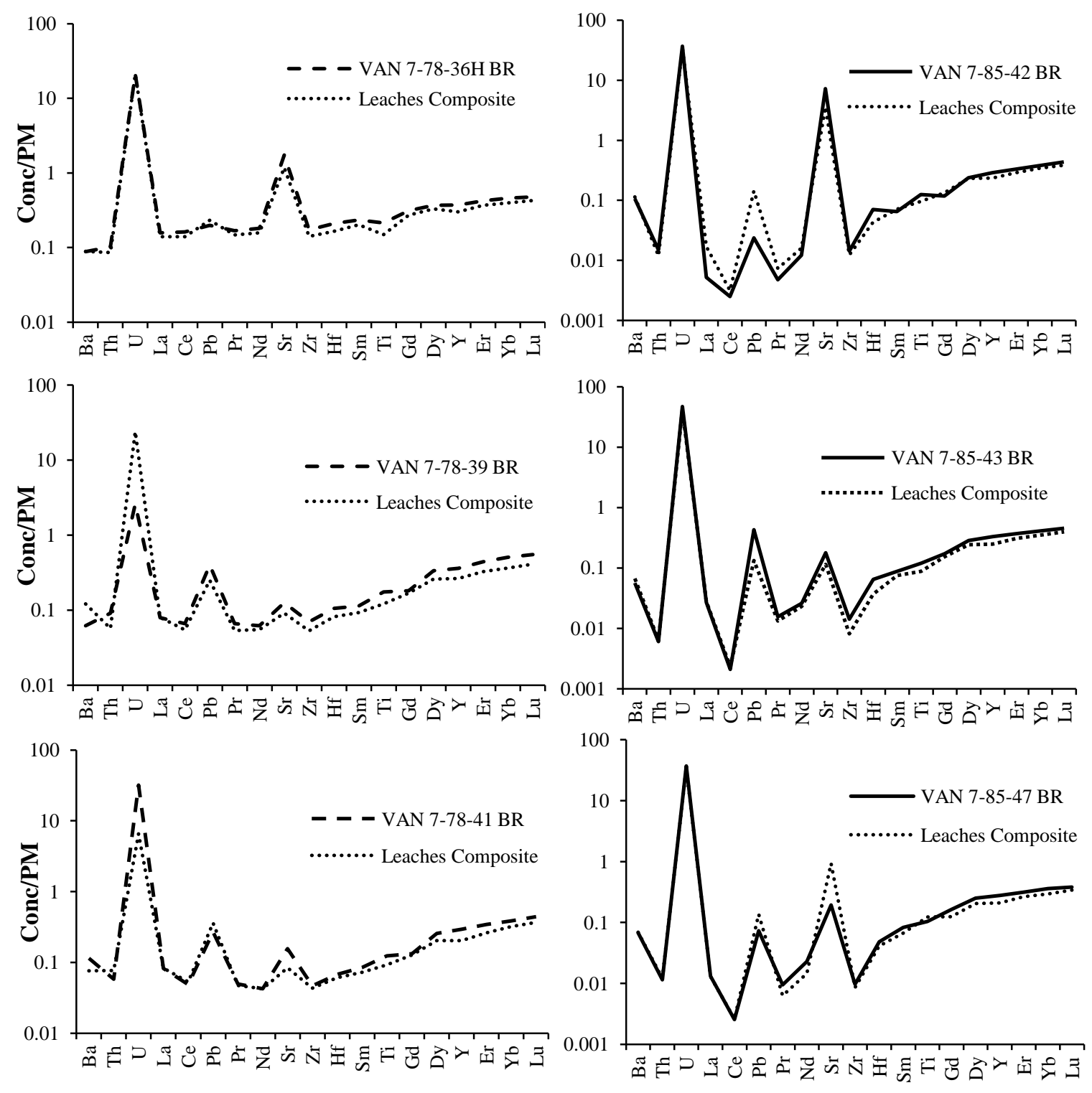



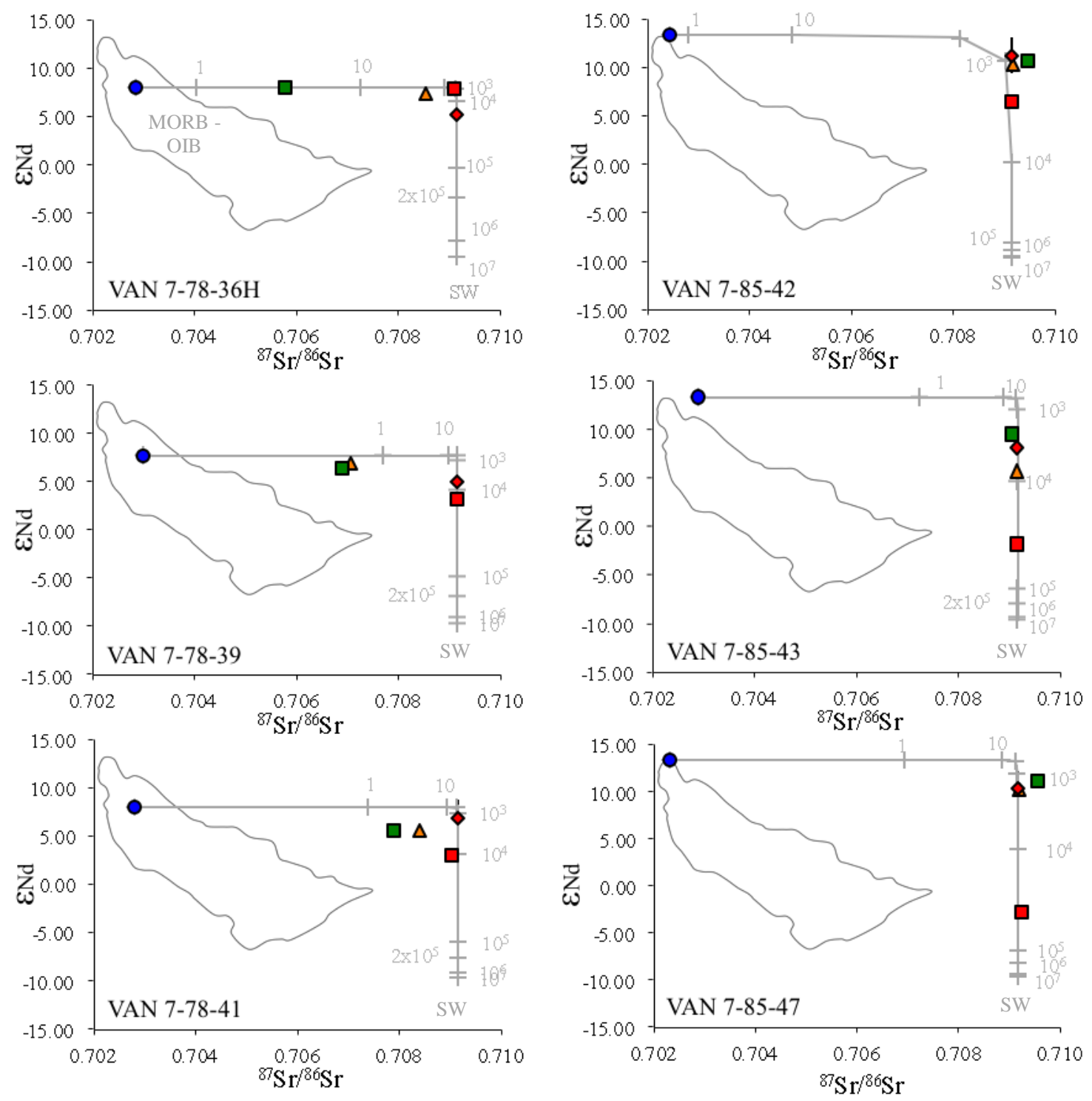

- CPX $\Delta_{\text {Bulk Rock }} \square_{\text {Residual Rock }} \square_{\mathrm{NaOAc}}+\mathrm{HH} \quad \diamond_{6 \mathrm{NHCL}}$ 

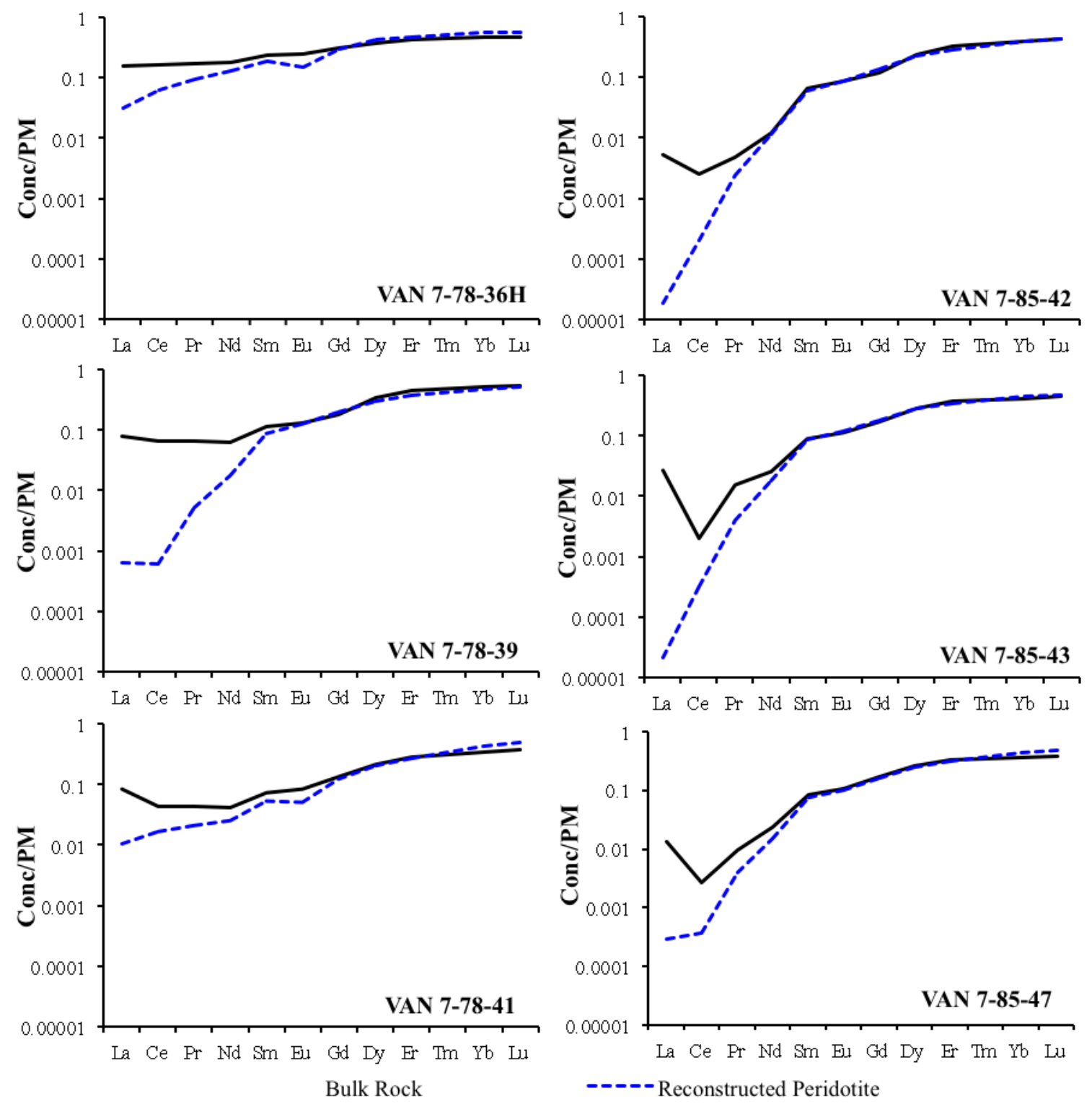


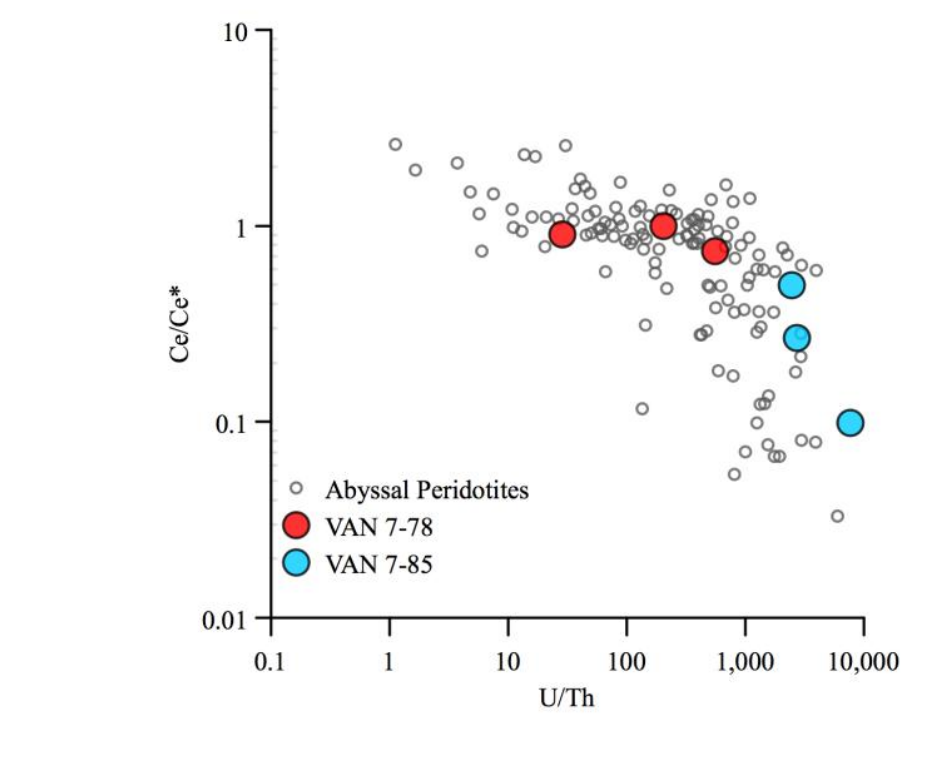

Figure 13

Fure 13

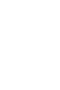




\section{TABLES}

Table 1: LA-ICP-MS Settings

\begin{tabular}{c|c}
\hline RF Power $(\mathrm{W})$ & 1200 \\
Ar Nebulizer flow $(\mathrm{L} / \mathrm{min})$ & $0.6-0.8$ \\
Ar Auxiliary gas $(\mathrm{L} / \mathrm{min})$ & 0.7 \\
Ar cooling gas $(\mathrm{L} / \mathrm{min})$ & 15 \\
$\mathrm{He}$ Carrier Gas $(\mathrm{L} / \mathrm{min})$ & $0.3-0.7$ \\
$\mathrm{ThO}^{+} / \mathrm{Th}^{+}(\%)$ & $<2$ \\
Laser-repetition rate $(\mathrm{Hz})$ & 8 \\
Spot size $(\mu \mathrm{m})$ & 110 \\
Energy Density $\left(\mathrm{J} / \mathrm{cm}^{2}\right)$ & Matrix - Dependent \\
\hline
\end{tabular}


Table 2: Average mineral phase major element concentrations from laser-ablation ICP-MS

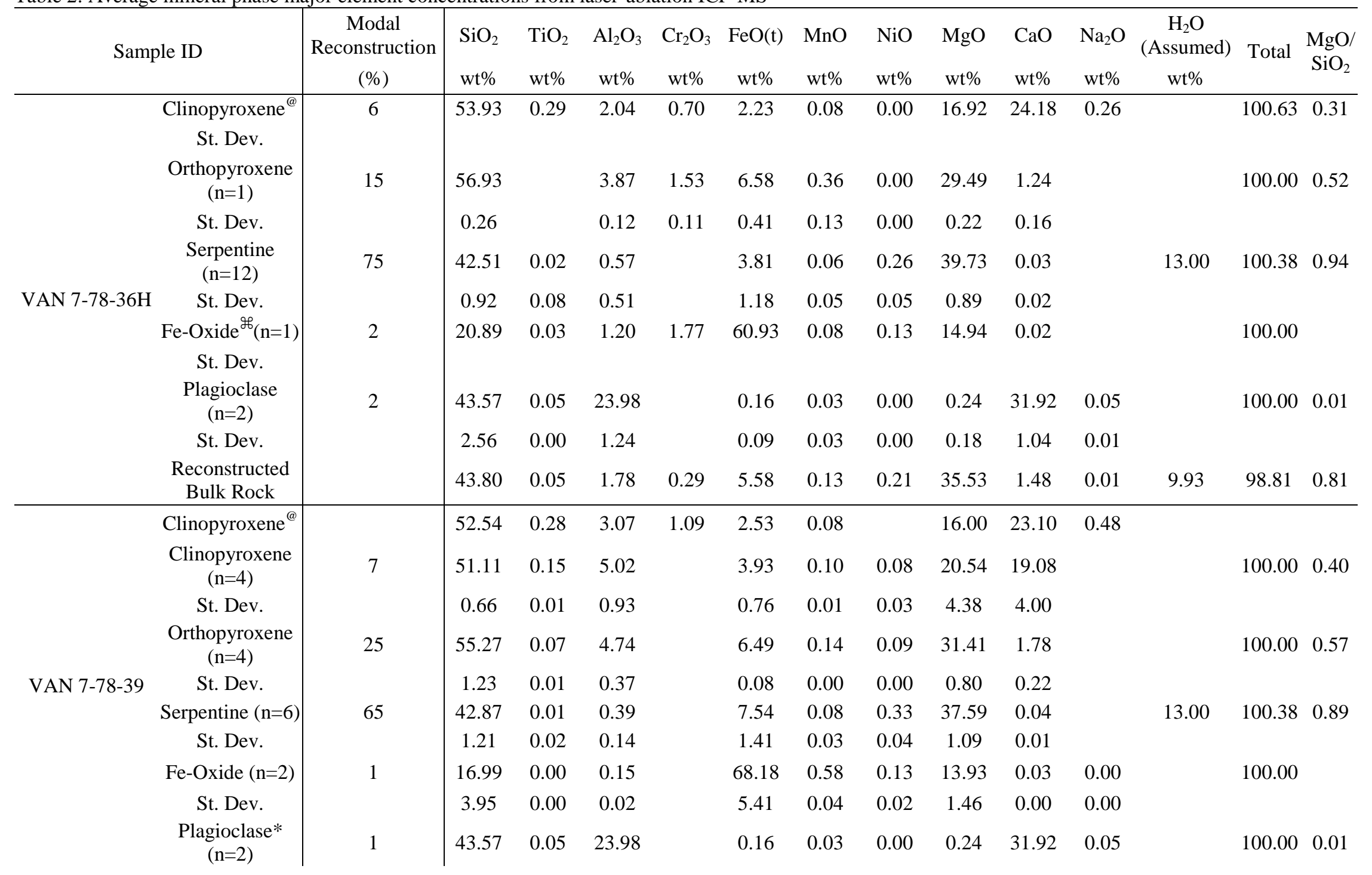




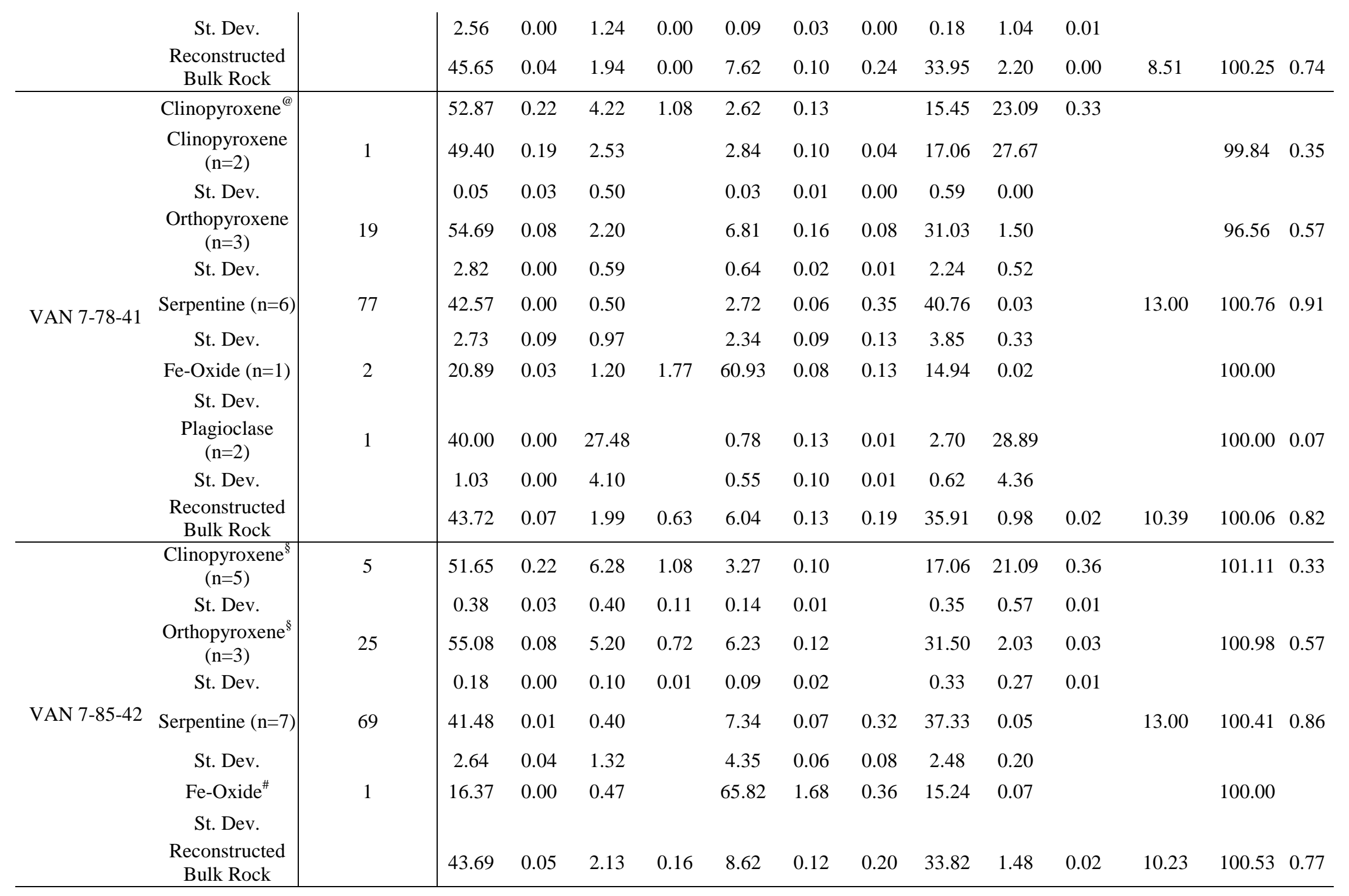




\begin{tabular}{|c|c|c|c|c|c|c|c|c|c|c|c|c|c|c|c|}
\hline \multirow{6}{*}{ VAN 7-85-43 } & $\begin{array}{c}\text { Clinopyroxene }^{\S} \\
(\mathrm{n}=4)\end{array}$ & 8 & 51.79 & 0.17 & 6.33 & 1.13 & 2.97 & 0.11 & & 16.68 & 21.03 & 0.40 & & 100.61 & 0.32 \\
\hline & $\begin{array}{c}\text { St. Dev. } \\
\text { Orthopyroxene } \\
(\mathrm{n}=1)\end{array}$ & 25 & 54.86 & & 7.20 & 1.22 & 6.13 & 0.14 & 0.16 & 28.34 & 1.92 & & & 99.97 & 0.52 \\
\hline & $\begin{array}{c}\text { Serpentine } \\
(\mathrm{n}=11)\end{array}$ & 66 & 41.13 & 0.00 & 0.43 & & 7.22 & 0.06 & 0.33 & 37.80 & 0.03 & & 13.00 & 100.33 & 0.92 \\
\hline & St. Dev. & & 0.54 & 0.00 & 0.13 & 0.00 & 0.83 & 0.01 & 0.02 & 0.41 & 0.00 & & & & \\
\hline & Fe-Oxide $(\mathrm{n}=1)$ & 1 & 16.37 & 0.00 & 0.47 & & 65.82 & 1.68 & 0.36 & 15.24 & 0.07 & & & 100.00 & \\
\hline & $\begin{array}{l}\text { Reconstructed } \\
\text { Bulk Rock }\end{array}$ & & 45.01 & 0.02 & 2.31 & 0.37 & 7.34 & 0.10 & 0.27 & 33.85 & 2.07 & 0.03 & 8.90 & 100.27 & 0.75 \\
\hline \multirow{8}{*}{ VAN 7-85-47 } & Clinopyroxene $e^{\S}$ & & 51.54 & 0.22 & 6.31 & 1.07 & 3.21 & 0.10 & & 17.08 & 20.88 & 0.37 & & & \\
\hline & $\begin{array}{c}\text { Clinopyroxene } \\
(\mathrm{n}=6)\end{array}$ & 5 & 51.17 & 0.16 & 5.76 & & 3.54 & 0.11 & 0.05 & 18.25 & 20.64 & & & 99.69 & 0.36 \\
\hline & St. Dev. & & 1.15 & 0.01 & 0.42 & & 2.37 & 0.00 & 0.00 & 0.92 & 1.45 & & & & \\
\hline & $\begin{array}{l}\text { Orthopyroxene } \\
\qquad(\mathrm{n}=1)\end{array}$ & 16 & 56.09 & 0.07 & 4.69 & & 6.18 & 0.14 & 0.09 & 30.93 & 1.80 & & & 100.00 & 0.55 \\
\hline & Serpentine $(n=6)$ & 78 & 42.46 & 0.01 & 1.16 & & 7.99 & 0.09 & 0.27 & 34.76 & 0.26 & & 13.00 & 100.38 & 0.84 \\
\hline & St. Dev. & & 2.21 & 0.01 & 1.16 & & 2.37 & 0.02 & 0.06 & 1.49 & 0.34 & & & & \\
\hline & Fe-Oxide ${ }^{\#}$ & 1 & 16.37 & 0.00 & 0.47 & & 65.82 & 1.68 & 0.36 & 15.24 & 0.07 & & & 100.00 & \\
\hline & $\begin{array}{l}\text { Reconstructed } \\
\text { Bulk Rock }\end{array}$ & & 44.61 & 0.03 & 1.69 & 0.00 & 8.33 & 0.11 & 0.24 & 33.45 & 1.63 & 0.00 & 10.19 & 100.28 & 0.75 \\
\hline
\end{tabular}

"n" equals the number of spots determined.

HAssumed magnetite from VAN 7-78-41.

\# Assumed magnetite from VAN 7-85-43.

* Assumed plagioclase from VAN 7-78-36H.

@ Major element data from Mallick et al., (2014).

$\S$ Major element data from Warren et al., (2009). 
Table 3: Average mineral phase trace element concentrations from laser-ablation ICP-MS

\begin{tabular}{|c|c|c|c|c|c|c|c|c|c|c|c|c|c|c|c|c|c|c|c|c|}
\hline \multirow{2}{*}{\multicolumn{2}{|c|}{ Sample ID }} & $\mathrm{Ba}$ & Th & U & $\mathrm{La}$ & $\mathrm{Ce}$ & $\mathrm{Pb}$ & $\operatorname{Pr}$ & $\mathrm{Nd}$ & $\mathrm{Sr}$ & $\mathrm{Zr}$ & $\mathrm{Hf}$ & $\mathrm{Sm}$ & $\mathrm{Ti}$ & Gd & Dy & $\mathrm{Y}$ & $\mathrm{Er}$ & $\mathrm{Yb}$ & $\mathrm{Lu}$ \\
\hline & & (ng/g) & $(\mathrm{ng} / \mathrm{g})$ & $(\mathrm{ng} / \mathrm{g})$ & $(\mathrm{ng} / \mathrm{g})$ & $(\mathrm{ng} / \mathrm{g})$ & $(\mathrm{ng} / \mathrm{g})$ & $(\mathrm{ng} / \mathrm{g})$ & $(\mathrm{ng} / \mathrm{g})$ & $(\mathrm{ug} / \mathrm{g})$ & ) $(\mathrm{ng} / \mathrm{g})$ & $(\mathrm{ng} / \mathrm{g})$ & $(n g / g)$ & (ug/g) & $(\mathrm{ng} / \mathrm{g})$ & $(n g / g)$ & $(\mathrm{ng} / \mathrm{g})$ & ) $(\mathrm{ng} / \mathrm{g})$ & $(\mathrm{ng} / \mathrm{g})$ & $(\mathrm{ng} / \mathrm{g})$ \\
\hline \multirow{11}{*}{$\begin{array}{c}\text { VAN 7-78- } \\
\quad 36 \mathrm{H}\end{array}$} & Bulk Rock & 580.6 & 8.12 & 425.4 & 101.8 & 271.2 & 29.87 & 42.89 & 226.6 & 34.48 & 81823.6 & 659.65 & 595.60 & 320.5 & 169.4 & 4248.6 & 51602 & 2185.7 & 201.9 & 932.35 \\
\hline & Clinopyrox & 0.00 & 7.27 & 52.89 & 310.0 & 1490 & 59.70 & 0.00 & 2200 & & 14810 & 480 & 1020 & 2093 & 1940 & 3090 & 17180 & 01930 & 1710 & 220.0 \\
\hline & $\begin{array}{l}\text { Orthopyroxene } \\
(\mathrm{n}=2)\end{array}$ & 0.95 & 8.02 & 3.11 & 3.98 & 25.10 & 10.73 & 5.50 & 38.63 & 0.0142 & 42805.5 & 579.63 & 322.54 & 869.6 & 573.38 & 3230.9 & 1858 & 8292.6 & 455.3 & 379.85 \\
\hline & St. Dev. & 4.38 & 4.47 & 1.10 & 3.02 & 24.51 & 0.96 & 5.45 & 39.50 & 0.002 & 22445.9 & 959.40 & 17.82 & 29.09 & 62.60 & 137.1 & 960.3 & $\begin{array}{ll}3134.8 \\
\end{array}$ & 136.2 & 219.55 \\
\hline & $\begin{array}{l}\text { Serpentine } \\
\quad(n=12)\end{array}$ & 241.2 & 3.42 & 878.7 & 27.17 & 64.84 & 32.63 & 12.01 & 68.94 & $1.491 \mathrm{C}$ & 1625.13 & 316.60 & 29.24 & 119.5 & 51.80 & 84.44 & 580.0 & 073.93 & 98.85 & 518.31 \\
\hline & St. Dev. & 207.9 & 1.39 & 426.9 & 13.00 & 52.09 & 12.76 & 6.34 & 41.38 & 0.370 & 469 & 17.69 & 918.22 & 63.70 & 32.6 & 48.9 & 285 & 37.0 & 32.2 & 5.3 \\
\hline & Fe-Oxide ${ }^{2 f}(n=2)$ & 136.8 & 10.42 & 208.9 & 21.64 & 67.50 & 38.41 & 13.07 & 54.42 & 0.997 & 7589.80 & 012.19 & 921.09 & 4349 & 20.70 & 33.46 & 162.7 & 722.13 & 22.73 & 5.85 \\
\hline & St. Dev. & 544.7 & 4.82 & 173.0 & 9.78 & 3.78 & 230.7 & 7.13 & 2.39 & 0.136 & 644.90 & 1.65 & 2.68 & 0.05 & 2.78 & 7.98 & 94.26 & $\begin{array}{ll}6 & 8.07\end{array}$ & 4.71 & 1.78 \\
\hline & $\begin{array}{l}\text { Plagioclase } \\
\quad(n=2)\end{array}$ & 3423 & 1.53 & 13.48 & 1295 & 2290 & 387.1 & 231.99 & 785.4 & 73.79 & 90.44 & 2.12 & 100.5 & 323.2 & 79.60 & 32.98 & 3158.4 & 412.54 & 7.31 & 2.51 \\
\hline & St. Dev. & 1179 & 0.55 & 7.08 & 268.7 & 244.2 & 11.65 & 29.81 & 114.5 & 19.17 & $\begin{array}{ll}7 & 0.00\end{array}$ & 1.42 & 9.71 & 28.38 & 0.88 & 1.58 & 4.81 & 4.62 & 1.18 & 1.84 \\
\hline & $\begin{array}{l}\text { cted } \\
\text { ck }\end{array}$ & 184.7 & 4.02 & 659.9 & 40.13 & 143.6 & 26.61 & 30.50 & 191.2 & 1.239 & 91788.9 & 95359 & 987.44 & 350.8 & 167.8 & 285.8 & 1757 & $\begin{array}{ll}7 & 216.7\end{array}$ & 246.5 & 39.21 \\
\hline \multirow{12}{*}{ VAN 7-78-39 } & B & 7.0 & 7.27 & 2.89 & 51.53 & 110.4 & 59.70 & 16.83 & 77.49 & & 729.78 & 829.73 & 346.02 & 262.9 & 98.96 & 5225.7 & 1548 & $\begin{array}{ll}8194.0 \\
\end{array}$ & 224.3 & 37.08 \\
\hline & $\begin{array}{l}\text { linopyroxene } \\
(\mathrm{n}=4)\end{array}$ & 4.46 & 2.88 & 54.40 & 4.98 & 11.35 & & 14.68 & 247.1 & $0.505=$ & 540502 & 117 & 9389.2 & 945.0 & 1034 & 1838 & 10788 & 81299 & 1221 & 177.9 \\
\hline & St. Dev. & 64.30 & 4.26 & 75.33 & 7.71 & 6.95 & 18.69 & 6.56 & 10.96 & 0.221 & 145.95 & 12.95 & 57.97 & 44.59 & 60.68 & 32.65 & 287.9 & 959.20 & 21.35 & 53.93 \\
\hline & $\begin{array}{l}\text { rthopyroxene } \\
(\mathrm{n}=4)\end{array}$ & 20.47 & 0.61 & 15.84 & 5.40 & 3.25 & 28.19 & 0.80 & 9.23 & 0.148 & 8115.68 & 823.47 & 720.3 & 440.7 & 68.53 & 3223.9 & 1795 & $\begin{array}{ll}5 & 261.4\end{array}$ & 385. & 69.56 \\
\hline & St. Dev. & 20.68 & 0.78 & 20.61 & 8.41 & 4.32 & 15.03 & 1.69 & 5.37 & 0.206 & 610.02 & 3.23 & 5.86 & 36.07 & 17.35 & 18.95 & 141.3 & $\begin{array}{ll}319.12\end{array}$ & 28.61 & 3.00 \\
\hline & $\begin{array}{l}\text { Serpentine } \\
\quad(n=6)\end{array}$ & 454.9 & 1.24 & 1401 & 2.79 & 2.14 & 59.17 & 1.38 & 6.99 & 2.183 & 331.19 & 2.65 & 9.64 & 48.89 & 31.66 & 63.80 & 491.5 & 563.67 & 81.87 & 715.96 \\
\hline & St. Dev. & 109.6 & 0.99 & 1603 & 3.38 & 1.89 & 44.85 & 1.43 & 3.38 & 1.1 & 17 & 1.33 & & 9.41 & & 60.0 & 523 & & & 15.5 \\
\hline & Fe-Oxide $(n=2)$ & 1312 & 4.80 & 424.7 & 9.82 & 15.68 & 95.99 & 5.64 & 17.01 & 3.630 & 89.01 & 7.48 & 23.34 & 9.66 & 48.05 & 75.42 & 416.9 & 961.31 & 54.83 & 312.57 \\
\hline & St. Dev. & 544.7 & 4.82 & 173.0 & 9.78 & 3.78 & 230.7 & 7.13 & 2.39 & 0.136 & 644.90 & 1.65 & 2.68 & 0.05 & 2.78 & 7.98 & 94.26 & $6 \quad 8.07$ & 4.71 & 1.78 \\
\hline & $\begin{array}{l}\text { Plagioclase* } \\
\qquad(\mathrm{n}=2)\end{array}$ & 3423 & 1.53 & 13.48 & 1295 & 2290 & 387.2 & 231.99 & 785.4 & 73.79 & 90.44 & 2.12 & 100.5 & 323.2 & 79.60 & 32.98 & 358.4 & 412.54 & 7.31 & 2.51 \\
\hline & St. Dev. & 1179 & 0.55 & 7.08 & 268.7 & 244.2 & 11.65 & 29.81 & 114.5 & 19.18 & $8 \quad 0.00$ & 1.42 & 9.71 & 28.38 & 0.88 & 1.58 & 4.81 & 4.62 & 1.18 & 1.84 \\
\hline & $\begin{array}{l}\text { Reconstructed } \\
\text { Bulk Rock }\end{array}$ & 366.2 & 1.38 & 929.9 & 7.42 & 7.42 & 48.43 & 2.76 & 26.75 & 2.085 & 587.19 & 16.54 & 440.85 & 212.7 & 115.5 & 235.4 & 1577 & $\begin{array}{l}7 \quad 204.3 \\
\end{array}$ & 241.4 & 41.28 \\
\hline \multirow[b]{2}{*}{ VAN 7-78-41 } & & 755.3 & 4.62 & 651.7 & & 81.78 & 40.65 & 12.61 & 53.12 & & & & 834.35 & 185.7 & 71.85 & 173.1 & 1271 & 1150.1 & 169.9 & 29.79 \\
\hline & $\begin{array}{c}\text { Clinopyroxene } \\
(\mathrm{n}=2)\end{array}$ & 195.2 & 39.60 & 20.06 & 385.7 & 1214 & 18.75 & 213.17 & 1167 & 0.786 & 66825.3 & 3274.3 & 3764.5 & 1140 & 1664 & 2862 & 16529 & 91927 & 1736 & 239.0 \\
\hline
\end{tabular}




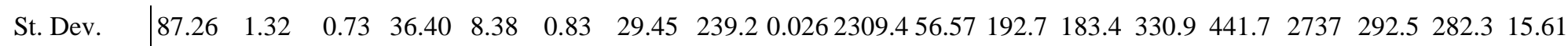

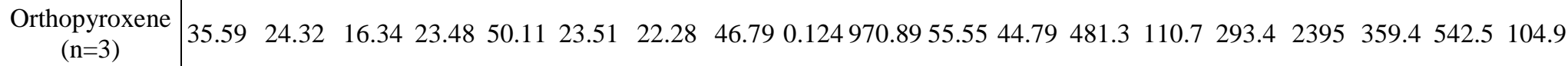

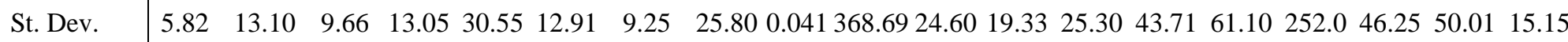

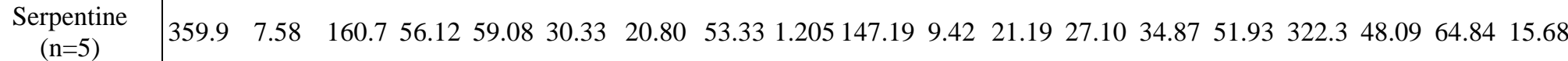

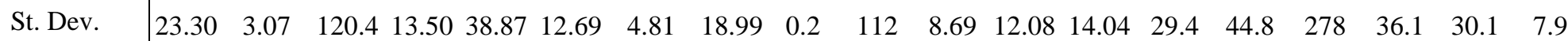

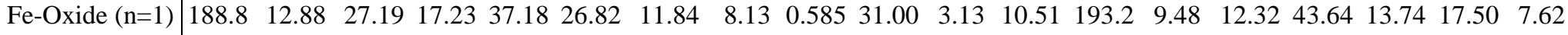
\begin{tabular}{l|lllllllllllllllllll} 
Plagioclase & 4403 & 15.35 & 18.76 & 376.9 & 418.9 & 40.44 & 50.73 & 134.9 & 55.20 & 11.15 & 10.01 & 31.33 & 24.31 & 41.96 & 36.89 & 162.8 & 21.04 & 17.29 & 8.86
\end{tabular} (n=2)

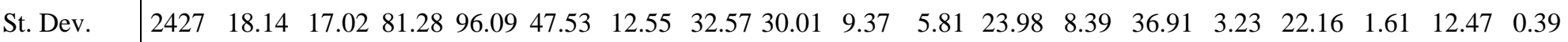

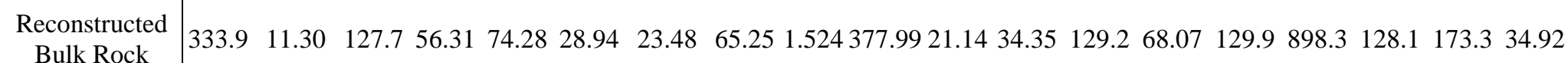

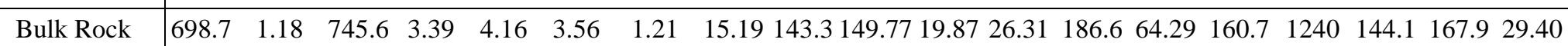

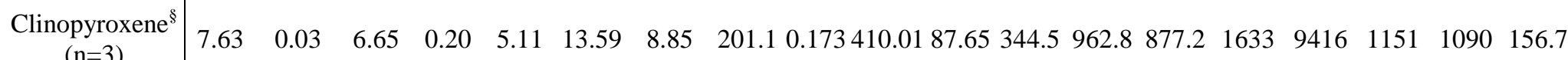

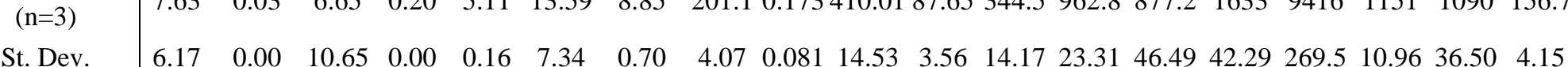

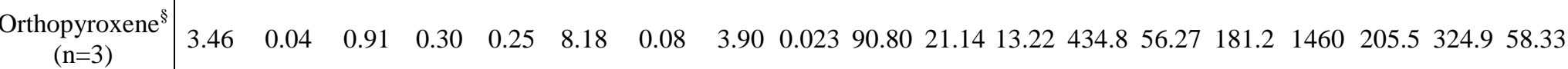

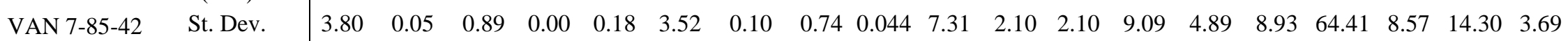
\begin{tabular}{l|lllllllllllllllllll} 
Serpentine & 108.5 & 0.09 & 1079 & 0.14 & 0.28 & 14.41 & 0.24 & 1.90 & 3.1 & 30 & 3.93 & 5.36 & 42.82 & 16.8 & 38.0 & 303 & 36.6 & 54.4 & 10.5
\end{tabular} \begin{tabular}{l|lllllllllllllllllll}
$(\mathrm{n}=7)$ & & & & &
\end{tabular}

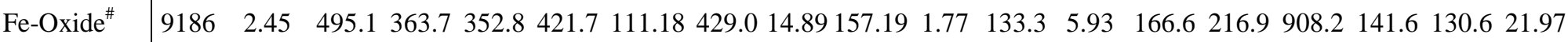
Reconstructed \begin{tabular}{l|lllllllllll} 
Bulk Rock & 157.6 & 0.10 & 754.9 & 3.39 & 3.60 & 16.41 & 1.59 & 15.55 & 2.266 & 64.43 & 12.14 \\
24.42 & 183.5 & 68.46 & 150.4 & 1025 & 132.1 & 171.3 & 29.40
\end{tabular}

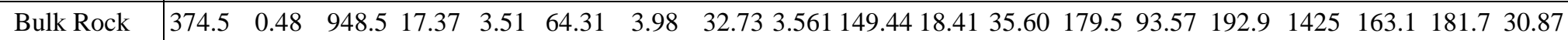

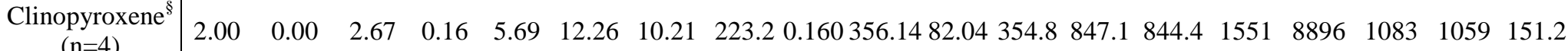

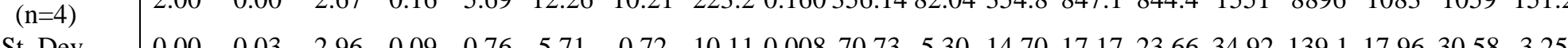
\begin{tabular}{l|lllllllllllllllllllllll} 
St. Dev. & 0.00 & 0.03 & 2.96 & 0.09 & 0.76 & 5.71 & 0.72 & 10.11 & 0.008 & 70.73 & 5.30 & 14.70 & 17.17 & 23.66 & 34.92 & 139.1 & 17.96 & 30.58 & 3.25
\end{tabular}

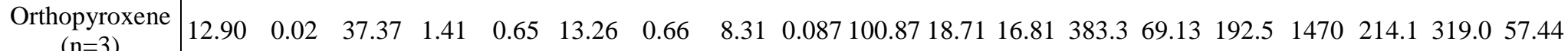
\begin{tabular}{l|lllllllllllllllllll} 
& \\
St. Dev. & 21.81 & 0.03 & 62.95 & 1.91 & 0.44 & 2.30 & 1.06 & 4.29 & 0.149 & 41.08 & 3.46 & 2.87 & 38.48 & 18.78 & 29.26 & 177.3 & 21.57 & 25.97 & 4.49
\end{tabular} \begin{tabular}{l|llllllllllllllllllll} 
Serpentine & 107.8 & 0.23 & 1094 & 7.68 & 0.99 & 33.96 & 2.57 & 11.78 & 1.895 & 105.17 & 3.11 & 6.76 & 15.63 & 17.36 & 33.57 & 240.5 & 30.37 & 42.15 & 7.70
\end{tabular} $(\mathrm{n}=11)$

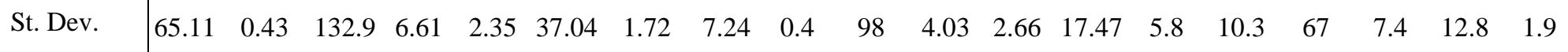

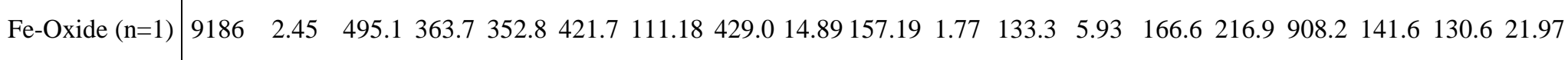


Reconstructed Bulk Rock

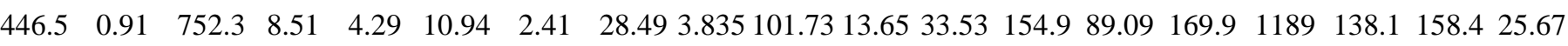

Bulk Rock

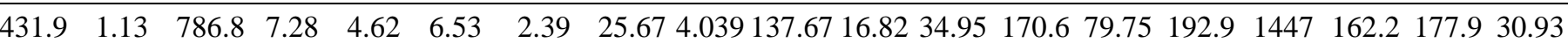

Clinopyroxene

$(n=6)$

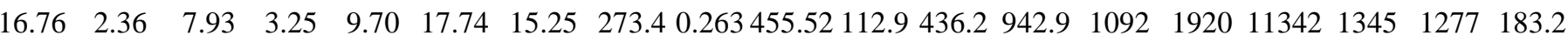

St. Dev.

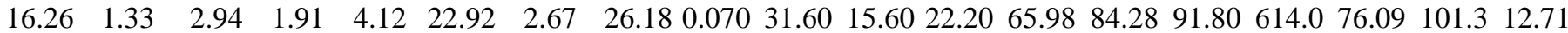

Orthopyroxene

$$
(n=1)
$$

Serpentine

$$
(n=6)
$$

15.800 .87

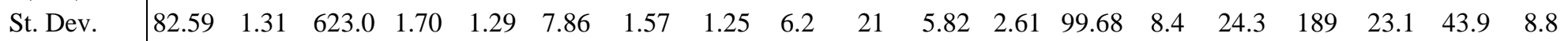

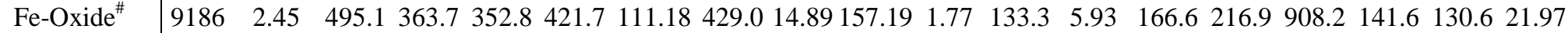

Reconstructed

Bulk Rock

"n" equals the number of spots determined.

HAssumed magnetite from VAN 7-78-41.

\# Assumed magnetite from VAN 7-85-43.

* Assumed plagioclase from VAN 7-78-36H.

@ Major element data from Mallick et al., (2014).

$\S$ Major element data from Warren et al., (2009). 
Table 4: Peridotite leachates and residual rock trace element concentrations

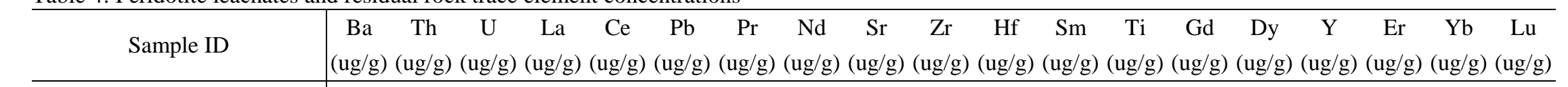

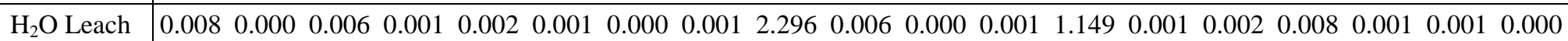

$\begin{array}{llllllllllllllllllllllll}\mathrm{NaOAc} \text { Leach } & 0.248 & 0.000 & 0.215 & 0.017 & 0.033 & 0.001 & 0.005 & 0.029 & 17.549 & 0.000 & 0.000 & 0.012 & 0.039 & 0.021 & 0.030 & 0.164 & 0.022 & 0.022 & 0.003\end{array}$

\begin{tabular}{ll|lllllllllllllllllll} 
VAN 7-78-36H & HH Leach & 0.141 & 0.001 & 0.104 & 0.011 & 0.026 & 0.011 & 0.004 & 0.018 & 2.506 & 0.002 & 0.000 & 0.007 & 0.171 & 0.012 & 0.019 & 0.100 & 0.014 & 0.018 & 0.003
\end{tabular}

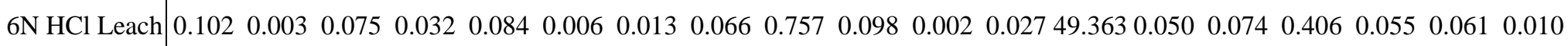
$\begin{array}{lllllllllllllllllllll}\text { Residual Rock } & 0.090 & 0.003 & 0.028 & 0.030 & 0.090 & 0.015 & 0.015 & 0.082 & 0.365 & 1.369 & 0.043 & 0.036 & 172.11 & 0.064 & 0.098 & 0.613 & 0.070 & 0.073 & 0.012\end{array}$ $\begin{array}{lllllllllllllllllllll}\mathrm{H}_{2} \mathrm{O} \text { Leach } & 0.010 & 0.000 & 0.007 & 0.000 & 0.000 & 0.000 & 0.000 & 0.000 & 0.160 & 0.002 & 0.000 & 0.000 & 0.635 & 0.000 & 0.001 & 0.005 & 0.001 & 0.001 & 0.000\end{array}$ \begin{tabular}{l|lllllllllllllllllll}
$\mathrm{NaOAc}$ Leach & 0.357 & 0.000 & 0.231 & 0.008 & 0.007 & 0.002 & 0.002 & 0.008 & 0.775 & 0.000 & 0.000 & 0.004 & 0.042 & 0.008 & 0.015 & 0.094 & 0.012 & 0.013 & 0.002
\end{tabular}

\begin{tabular}{ll|lllllllllllllllllllllll} 
VAN 7-78-39 & HH Leach & 0.232 & 0.000 & 0.106 & 0.006 & 0.007 & 0.010 & 0.001 & 0.006 & 0.340 & 0.001 & 0.000 & 0.003 & 0.074 & 0.007 & 0.011 & 0.070 & 0.009 & 0.013 & 0.002
\end{tabular} \begin{tabular}{ll|llllllllllllllllllll}
$6 \mathrm{~N}$ HCl Leach & 0.060 & 0.001 & 0.136 & 0.013 & 0.020 & 0.007 & 0.003 & 0.014 & 0.340 & 0.026 & 0.001 & 0.008 & 35.400 & 0.020 & 0.041 & 0.248 & 0.036 & 0.041 & 0.007
\end{tabular}

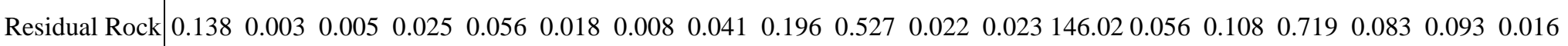
$\begin{array}{llllllllllllllllllllllll}\mathrm{H}_{2} \mathrm{O} \text { Leach } & 0.005 & 0.000 & 0.001 & 0.000 & 0.000 & 0.000 & 0.000 & 0.000 & 0.137 & 0.002 & 0.000 & 0.000 & 0.758 & 0.000 & 0.000 & 0.003 & 0.000 & 0.001 & 0.000\end{array}$ $\begin{array}{lllllllllllllllllllllll}\mathrm{NaOAc} \text { Leach } & 0.164 & 0.000 & 0.025 & 0.006 & 0.007 & 0.001 & 0.001 & 0.006 & 0.433 & 0.001 & 0.000 & 0.003 & 0.035 & 0.005 & 0.010 & 0.067 & 0.010 & 0.012 & 0.002\end{array}$

\begin{tabular}{ll|llllllllllllllllllllllllllllll} 
VAN 7-78-41 & HH Leach & 0.071 & 0.001 & 0.009 & 0.005 & 0.006 & 0.007 & 0.001 & 0.004 & 0.216 & 0.000 & 0.000 & 0.002 & 0.155 & 0.003 & 0.006 & 0.035 & 0.005 & 0.008 & 0.001
\end{tabular}

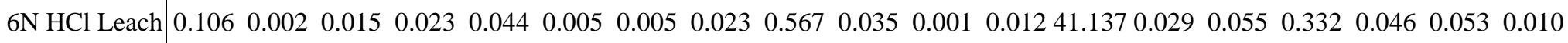
\begin{tabular}{l|lllllllllllllllllll} 
Residual Rock & 0.160 & 0.003 & 0.083 & 0.020 & 0.032 & 0.042 & 0.004 & 0.021 & 0.317 & 0.419 & 0.016 & 0.013 & 96.597 & 0.031 & 0.066 & 0.440 & 0.054 & 0.069 & 0.012
\end{tabular} $\begin{array}{lllllllllllllllllllllll}\mathrm{H}_{2} \mathrm{O} \text { Leach } & 0.005 & 0.000 & 0.010 & 0.000 & 0.000 & 0.000 & 0.000 & 0.000 & 0.246 & 0.001 & 0.000 & 0.000 & 0.313 & 0.000 & 0.000 & 0.002 & 0.000 & 0.000 & 0.000\end{array}$ $\begin{array}{llllllllllllllllllllll}\mathrm{NaOAc} \text { Leach } & 0.398 & 0.000 & 0.417 & 0.001 & 0.000 & 0.000 & 0.000 & 0.002 & 70.086 & 0.001 & 0.000 & 0.003 & 0.067 & 0.006 & 0.014 & 0.093 & 0.013 & 0.014 & 0.003\end{array}$

$\begin{array}{llllllllllllllllllllllllllllll}\text { VAN 7-85-42 } & \text { HH Leach } & 0.110 & 0.000 & 0.193 & 0.003 & 0.001 & 0.005 & 0.001 & 0.003 & 0.523 & 0.002 & 0.000 & 0.002 & 0.186 & 0.004 & 0.006 & 0.044 & 0.006 & 0.008 & 0.001\end{array}$ $6 \mathrm{~N} \mathrm{HCl} \mathrm{Leach} \begin{array}{lllllllllllllllllll}0.118 & 0.000 & 0.068 & 0.001 & 0.001 & 0.001 & 0.001 & 0.008 & 0.277 & 0.013 & 0.001 & 0.011 & 43.816 & 0.028 & 0.056 & 0.325 & 0.045 & 0.046 & 0.007\end{array}$ \begin{tabular}{l|lllllllllllllllllll} 
Residual Rock & 0.117 & 0.001 & 0.015 & 0.006 & 0.003 & 0.015 & 0.001 & 0.007 & 0.356 & 0.112 & 0.010 & 0.013 & 99.961 & 0.035 & 0.080 & 0.547 & 0.063 & 0.082 & 0.014
\end{tabular} $\begin{array}{lllllllllllllllllllllllll}\mathrm{H}_{2} \mathrm{O} \text { Leach } & 0.004 & 0.000 & 0.007 & 0.000 & 0.000 & 0.000 & 0.000 & 0.000 & 0.248 & 0.001 & 0.000 & 0.000 & 0.484 & 0.000 & 0.000 & 0.003 & 0.000 & 0.001 & 0.000\end{array}$ NaOAc Leach \begin{tabular}{l|lllllllllllllllllll}
0.190 & 0.000 & 0.490 & 0.005 & 0.000 & 0.000 & 0.001 & 0.005 & 1.360 & 0.000 & 0.000 & 0.003 & 0.045 & 0.009 & 0.016 & 0.116 & 0.015 & 0.016 & 0.003
\end{tabular}

$\begin{array}{lllllllllllllllllllllllllll}\text { VAN 7-85-43 } & \text { HH Leach } & 0.110 & 0.000 & 0.221 & 0.006 & 0.001 & 0.007 & 0.001 & 0.006 & 0.411 & 0.002 & 0.000 & 0.004 & 0.172 & 0.009 & 0.017 & 0.102 & 0.014 & 0.019 & 0.003\end{array}$ $\begin{array}{lllllllllllllllllllll}6 \mathrm{~N} \mathrm{HCl} \text { Leach } & 0.058 & 0.000 & 0.102 & 0.002 & 0.001 & 0.003 & 0.001 & 0.008 & 0.173 & 0.007 & 0.001 & 0.010 & 48.134 & 0.028 & 0.055 & 0.328 & 0.044 & 0.047 & 0.008\end{array}$

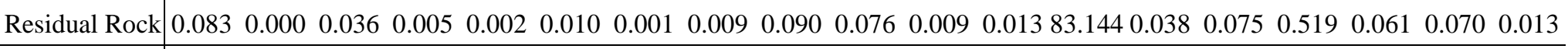
$\begin{array}{lllllllllllllllllllll}\mathrm{H}_{2} \mathrm{O} \text { Leach } & 0.011 & 0.000 & 0.010 & 0.000 & 0.000 & 0.000 & 0.000 & 0.000 & 5.049 & 0.000 & 0.000 & 0.000 & 0.788 & 0.000 & 0.001 & 0.004 & 0.001 & 0.001 & 0.000\end{array}$ \begin{tabular}{l|lllllllllllllllllllllll}
$\mathrm{NaOAc}$ Leach & 0.180 & 0.000 & 0.430 & 0.002 & 0.000 & 0.002 & 0.000 & 0.002 & 1.512 & 0.001 & 0.000 & 0.001 & 0.035 & 0.003 & 0.007 & 0.056 & 0.006 & 0.007 & 0.002
\end{tabular}

\begin{tabular}{ll|lllllllllllllllllllllllllll} 
VAN7-85-47 & HH Leach & 0.148 & 0.000 & 0.186 & 0.001 & 0.001 & 0.004 & 0.000 & 0.001 & 11.216 & 0.002 & 0.000 & 0.002 & 0.155 & 0.005 & 0.011 & 0.074 & 0.012 & 0.016 & 0.003
\end{tabular} $\begin{array}{llllllllllllllllllllll}6 \mathrm{~N} \mathrm{HCl} \text { Leach } & 0.063 & 0.000 & 0.042 & 0.000 & 0.001 & 0.002 & 0.000 & 0.003 & 0.665 & 0.007 & 0.001 & 0.005 & 37.985 & 0.012 & 0.028 & 0.171 & 0.025 & 0.028 & 0.005\end{array}$

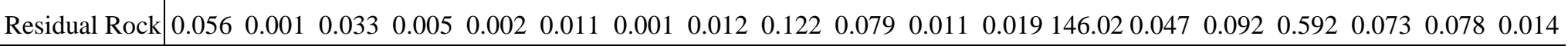


Table 5: ${ }^{87} \mathrm{Sr} /{ }^{86} \mathrm{Sr}$ and $\varepsilon_{\mathrm{Nd}}$ Isotopes for Bulk Rock, primary CPX, Leachates and Residual rock.

\begin{tabular}{|c|c|c|c|c|c|c|}
\hline & & ${ }^{87} \mathrm{Sr} /{ }^{86} \mathrm{Sr}$ & $2 \sigma$ & $\varepsilon_{\mathrm{Nd}}$ & $2 \sigma$ & $\begin{array}{c}\% \text { SW Nd } \\
\text { contribution }^{@}\end{array}$ \\
\hline \multirow{5}{*}{ VAN 7-78-36H } & Bulk Rock & 0.708543 & 0.000005 & 7.26 & 0.10 & \\
\hline & $\mathrm{NaOAc}+\mathrm{HH}$ Leach & 0.709108 & 0.000004 & 7.78 & 0.06 & \\
\hline & 6N HCl Leach & N.D. & & 5.17 & 1.84 & 3 \\
\hline & Residual rock & 0.705788 & 0.000020 & 8.00 & 0.06 & 1 \\
\hline & CPX & 0.702858 & 0.000019 & 7.92 & 0.37 & 14 \\
\hline \multirow{5}{*}{ VAN 7-78-39 } & Bulk Rock & 0.707067 & 0.000007 & 6.85 & 0.08 & 0 \\
\hline & $\mathrm{NaOAc}+\mathrm{HH}$ Leach & N.D. & & 3.15 & 0.23 & \\
\hline & 6N HCl Leach & N.D. & & 5.05 & 0.08 & 4 \\
\hline & Residual rock & 0.706889 & 0.000006 & 6.43 & 0.10 & 24 \\
\hline & CPX & 0.702992 & 0.000007 & 7.67 & 0.18 & 14 \\
\hline \multirow{5}{*}{ VAN 7-78-41 } & Bulk Rock & 0.708411 & 0.000007 & 5.46 & 0.08 & 6 \\
\hline & $\mathrm{NaOAc}+\mathrm{HH}$ Leach & 0.709039 & 0.000028 & 2.98 & 0.14 & \\
\hline & 6N HCl Leach & N.D. & & 6.84 & 0.10 & 13 \\
\hline & Residual rock & 0.706889 & 0.000006 & 5.56 & 0.10 & 26 \\
\hline & CPX & 0.707895 & 0.000008 & 7.96 & 0.41 & 6 \\
\hline \multirow{5}{*}{ VAN 7-85-42 } & Bulk Rock & 0.709175 & 0.000008 & 10.26 & 0.18 & 12 \\
\hline & $\mathrm{NaOAc}+\mathrm{HH}$ Leach & 0.709163 & 0.000003 & 6.42 & 0.25 & \\
\hline & $6 \mathrm{~N} \mathrm{HCl} \mathrm{Leach}$ & N.D. & & 11.17 & 0.24 & 12 \\
\hline & Residual rock & 0.709463 & 0.000008 & 10.59 & 0.12 & 28 \\
\hline & CPX & 0.702440 & 0.000017 & 13.28 & 0.27 & 9 \\
\hline \multirow{5}{*}{ VAN 7-85-43 } & Bulk Rock & 0.709143 & 0.000008 & 5.70 & 0.27 & 11 \\
\hline & $\mathrm{NaOAc}+\mathrm{HH}$ Leach & N.D. & & -1.81 & 0.14 & \\
\hline & 6N HCl Leach & N.D. & & 8.08 & 1.12 & 31 \\
\hline & Residual rock & 0.709044 & 0.000010 & 9.54 & 1.35 & 61 \\
\hline & CPX & 0.702902 & 0.000147 & 13.30 & 0.41 & 21 \\
\hline \multirow{5}{*}{ VAN 7-85-47 } & Bulk Rock & 0.709199 & 0.000008 & 10.24 & 0.55 & 15 \\
\hline & $\mathrm{NaOAc}+\mathrm{HH}$ Leach & 0.709250 & 0.000009 & -2.80 & 0.22 & \\
\hline & $6 \mathrm{~N} \mathrm{HCl} \mathrm{Leach}$ & N.D. & & 10.33 & 0.11 & 13 \\
\hline & Residual rock & 0.709568 & 0.000007 & 11.12 & 0.14 & 65 \\
\hline & CPX & 0.702308 & 0.000013 & 13.36 & 0.06 & 12 \\
\hline
\end{tabular}

* From Table 1 Station 101 at 4400m depth in Stichel et al (2012).

@ Calculated from equation 3 using measured bulk rock, CPX and seawater $\varepsilon_{\mathrm{Nd}}$. 
Table 6: Water/Rock ratio bulk rock and sans CPX models

\begin{tabular}{|c|c|c|c|c|c|c|c|c|c|c|c|}
\hline & $\begin{array}{l}\text { Sr Conc } \\
(\mathrm{ppm})\end{array}$ & $\begin{array}{l}\text { Nd Conc } \\
(\mathrm{ppm})\end{array}$ & $\begin{array}{c}\text { Primary } \\
\text { Magmatic } \\
{ }^{87} \mathrm{Sr}^{86} \mathrm{Sr}^{\S}\end{array}$ & $\begin{array}{c}\text { Primary } \\
\text { Magmatic } \\
\varepsilon_{\mathrm{Nd}}\end{array}$ & $\begin{array}{l}\text { Bulk Rock } \\
{ }^{87} \mathrm{Sr} /{ }^{86} \mathrm{Sr}\end{array}$ & $\begin{array}{c}\text { Bulk Rock } \\
\varepsilon_{\mathrm{Nd}}\end{array}$ & $\begin{array}{c}\text { Closed BR } \\
\text { W/R }\end{array}$ & $\begin{array}{l}\text { Open BR } \\
\text { W/R }\end{array}$ & $\begin{array}{c}\text { Closed BR } \\
\text { W/R }\end{array}$ & $\begin{array}{l}\text { Open BR } \\
\mathrm{W} / \mathrm{R}^{\#}\end{array}$ & $\begin{array}{c}\mathrm{Nd} \\
\text { addition } \\
\mathrm{W} / \mathrm{R}^{\varnothing}\end{array}$ \\
\hline SWIR Seawater* & 8 & $2.00 \times 10^{-6}$ & & & 0.70916 & -9.70 & & & & & \\
\hline Van 7-78-36H BR & 34.47 & 0.23 & 0.702858 & 7.92 & 0.708543 & 7.26 & 39.72 & 10.02 & - & - & - \\
\hline $\begin{array}{c}\text { Van } 7-78-36 \mathrm{H} \mathrm{BR} \\
\text { without CPX }\end{array}$ & 34.26 & 0.17 & & & & 7.04 & 41.02 & 10.14 & - & - & \\
\hline Van 7-78-39 BR & 2.50 & 0.08 & 0.702992 & 7.67 & 0.707067 & 6.85 & 0.61 & 0.34 & - & - & - \\
\hline $\begin{array}{c}\text { Van 7-78-39 BR } \\
\text { without CPX }\end{array}$ & 2.45 & 0.06 & & & & 6.59 & 0.63 & 0.34 & - & - & \\
\hline Van 7-78-41 BR & 3.11 & 0.05 & 0.702800 & 5.56 & 0.708411 & 5.46 & 2.91 & 0.83 & - & - & - \\
\hline $\begin{array}{c}\text { Van 7-78-41 BR } \\
\text { without CPX }\end{array}$ & 3.11 & 0.05 & & & & 5.41 & 2.92 & 0.83 & - & - & \\
\hline Van 7-85-42 BR & 143.35 & 0.02 & 0.702440 & 13.28 & 0.709175 & 10.26 & - & - & 1150.27 & 1071.06 & 927.52 \\
\hline $\begin{array}{c}\text { Van 7-85-42 BR } \\
\text { without CPX } \\
\end{array}$ & 143.33 & 0.01 & & & & 4.99 & - & - & 1562.87 & 1239.12 & \\
\hline Van 7-85-43 BR & 3.56 & 0.03 & 0.702902 & 13.30 & 0.709143 & 5.70 & - & - & 8085.29 & 6570.33 & 5024.71 \\
\hline $\begin{array}{c}\text { Van 7-85-43 BR } \\
\text { without CPX }\end{array}$ & 3.54 & 0.02 & & & & -2.72 & - & - & 17829.42 & 9263.89 & \\
\hline Van 7-85-47 BR & 4.04 & 0.03 & 0.702308 & 13.36 & 0.709199 & 10.24 & - & - & 2229.37 & 2071.21 & 1790.26 \\
\hline $\begin{array}{c}\text { Van 7-85-47 BR } \\
\text { without CPX } \\
\end{array}$ & 4.01 & 0.01 & & & & 6.88 & - & - & 2680.59 & 2262.90 & \\
\hline
\end{tabular}

$\S$ Derived from primary clinopyroxene for each sample.

* From Table 1 Station 101 at 4400m depth in Stichel et al (2012).

$\sim$ W/R determining from $\mathrm{Sr}$ isotopes using equations used from Delacour et al (2008).

\# W/R determining from $\mathrm{Nd}$ isotopes using equations used from Delacour et al (2008).

$\notin$ Addition from the determined $\mathrm{Nd}$ difference between the measured bulk rock and reconstructed primary peridotite. 